\title{
WestVirginiaUniversity
}

THE RESEARCH REPOSITORY @ WVU

Graduate Theses, Dissertations, and Problem Reports

2019

\section{A Compendium of Opera in Spain and Latin America}

Michelle S. Smith

West Virginia University, chellesmith01@gmail.com

Follow this and additional works at: https://researchrepository.wvu.edu/etd

Part of the Musicology Commons, Music Performance Commons, and the Other Music Commons

\section{Recommended Citation}

Smith, Michelle S., "A Compendium of Opera in Spain and Latin America" (2019). Graduate Theses, Dissertations, and Problem Reports. 3888.

https://researchrepository.wvu.edu/etd/3888

This Dissertation is protected by copyright and/or related rights. It has been brought to you by the The Research Repository @ WVU with permission from the rights-holder(s). You are free to use this Dissertation in any way that is permitted by the copyright and related rights legislation that applies to your use. For other uses you must obtain permission from the rights-holder(s) directly, unless additional rights are indicated by a Creative Commons license in the record and/ or on the work itself. This Dissertation has been accepted for inclusion in WVU Graduate Theses, Dissertations, and Problem Reports collection by an authorized administrator of The Research Repository @ WVU.

For more information, please contact researchrepository@mail.wvu.edu. 
A Compendium of Opera in Spain and Latin America

\author{
Michelle S. Smith \\ A Doctoral Research Document submitted \\ to the College of Creative Arts \\ at West Virginia University \\ in partial fulfillment of the requirements for the degree of \\ Doctor of Musical Arts in \\ Voice Performance
}

\author{
Hope Koehler, DMA, Chair and Research Advisor \\ Robert Chafin, MM \\ Matthew Heap, PhD \\ Mikylah Myers, DMA \\ Pablo García Loaeza, PhD \\ School of Music
}

Morgantown, West Virginia

2019

Keywords: Opera, Opera Composers, Spain, Latin America, Mexico, South America, Argentina, Chile, Colombia, Paraguay, Peru, Uruguay, Venezuela, Caribbean, Cuba, Dominican Republic, Guatemala, Puerto Rico, Central America

Copyright 2019 Michelle S. Smith 


\section{ABSTRACT \\ A Compendium of Opera in Spain and Latin America}

Michelle S. Smith

Spain and Latin America have a rich operatic tradition, however this opulent body of operatic work is mostly overlooked or ignored in mainstream histories of opera. This document focuses on opera in Spain and the Spanish-speaking countries of Latin America. Opera was both composed and performed in Spain and Latin America, and both regions demonstrate the development of national opera traditions. Spanish drama was closely linked to the beginnings of national opera, and Italian influence is evident in opera compositions from both regions. The output of national operas varies by country, with Spain, Mexico, and Argentina claiming the majority of operas from Spanish-speaking countries. 


\section{Table of Contents}

Chapter 1: Introduction

Chapter 2: Spain

Spain: Operas and Composers 10

Chapter 3: Mexico $\quad 25$

Mexico: Operas and Composers $\quad 29$

Chapter 4: South America $\quad 47$

Argentina: Operas and Composers $\quad 49$

Chile: Operas and Composers $\quad 66$

Colombia: Operas and Composers $\quad 67$

$\begin{array}{ll}\text { Paraguay: Operas and Composers } & 67\end{array}$

$\begin{array}{ll}\text { Peru: Operas and Composers } & 68\end{array}$

Uruguay: Operas and Composers $\quad 71$

Venezuela: Operas and Composers $\quad 73$

Chapter 5: Central America and the Caribbean $\quad 74$

Cuba: Operas and Composers $\quad 74$

Dominican Republic: Operas and Composers $\quad 77$

$\begin{array}{ll}\text { Guatemala: Operas and Composers } & 77\end{array}$

$\begin{array}{ll}\text { Puerto Rico: Operas and Composers } & 78\end{array}$

$\begin{array}{ll}\text { Chapter 6: Conclusion } & 79\end{array}$

Appendix A: Spain: Operas in Chronological Order $\quad 81$

Appendix B: Spain: Operas and Composers 84

Appendix C: Mexico: Operas in Chronological Order 88

Appendix D: Mexico: Operas and Composers 92

Appendix E: South America: Operas in Chronological Order 97

Appendix F: South America: Operas and Composers 101

Appendix G: South America: Operas by Country 107

Appendix H: Central America and the Caribbean: Operas in Chronological Order 112

Appendix I: Central America and the Caribbean: Operas and Composers 113

Appendix J: Central America and the Caribbean: Operas by Country 114

$\begin{array}{ll}\text { Bibliography } & 115\end{array}$ 


\section{Chapter 1: Introduction}

Spain and Latin America have a rich operatic tradition, however this opulent body of operatic work is mostly overlooked or ignored in mainstream histories of opera. Lack of knowledge about Spanish opera is linked to a general lack of awareness about Spanish culture and contributions in the world throughout history. ${ }^{1}$ There is a great need to explore these countries, their peoples, cultures, and musical heritages. As World Music studies have grown in popularity, an interest in the indigenous music of Latin America has increased. Despite this growth in the interest of World Music, there is still limited available information about Latin American and Spanish music, and especially of art music, such as opera, from these regions. There is more information regarding Spanish opera written in Spanish than in English, but even in the Spanish language, research is sparse. Sources that are cited as discussing opera in Spain or in a Latin American country, are often presenting information about Italian operas that have been performed at the various theaters of the country, but either do not include information about a national opera, or mention it only briefly.

This document focuses on opera in Spain and the Spanish-speaking countries of Latin America. Mexico, Central America, the Caribbean, and several South American nations are included in the Latin American portion of this research. There is only one Central American nation discussed in this research, Guatemala. The other countries of Central America are not discussed either due to a lack of information about opera development in those countries, or possibly a lack of the development of a national opera in those countries. As with most of Latin America, Italian opera was presented in Central America, but information about a national opera

\footnotetext{
${ }^{1}$ Chad M. Gasta, Transatlantic Arias: Early Opera in Spain and the New World (Lanham, Maryland: Scarecrow Press, Inc., 2002), 11.
} 
for the majority of the countries is not found. The focal point of this research is on Spanish and Latin American national opera: opera composed by Spanish and Latin American composers, composed in the Spanish language, and/or composed using native musical elements from these countries and regions.

Spain is a country geographically isolated from the majority of the European continent. Water surrounds large parts of the country in the north, south, and east. Portugal is on the western side, and France is on the northeastern side. However, the Pyrenees Mountains form a border that separates Spain and France, isolating Spain and Portugal from the other European nations, and forming the Iberian peninsula (along with some smaller areas belonging to other countries). This isolation from the rest of the continent contributed to the development of music at a different pace and in different ways than the rest of Europe. The countries of Latin America are significantly more separated than Spain from other European countries, and thus from the development of art music and opera.

In the seventeenth century, Italy and Germany had a developing opera culture. However, in Spain, opera was not cultivated until the eighteenth century. Once it evolved in Spain, opera began moving across the Atlantic and was imported into the Spanish colonies of the New World. Early opera in Spain, and in the Americas, developed under highly political situations. Opera productions often coincided with historical and political events, either to celebrate or to benefit a particular person or moment. ${ }^{2}$

Italian opera was key in the development of a national opera both in Spain and in Latin America. Musical styles and history were affected by the presence and integration of Italian

\footnotetext{
${ }^{2}$ Gasta, Transatlantic Arias: Early Opera in Spain and the New World, 12-13.
} 
musicians in Spain. ${ }^{3}$ By the early eighteenth century, the Spanish court was dominated by foreign musicians and composers. Both the Habsburg and the Bourbon dynasties were detrimental to purely national music traditions. The Habsburgs brought Italian musicians to perform in Barcelona and the Bourbons did the same in Madrid. This influx of foreigners did not completely dismiss the Spanish style, but it did impact all genres of art music, including opera. ${ }^{4}$

In 1703, the Royal Italian Company presented El pomo d'oro para la más hermosa in a court performance. This is recognized as the beginning of a permanent acceptance of Italian opera in Spain. ${ }^{5}$ Italian opera was officially presented in Lima in 1708 and, from that point moving forward, Italian musicians continued to monopolize the Peruvian stage. Italian opera also began to appear regularly in Buenos Aires during the eighteenth century. Foreign opera was so popular in Argentina that at least ten theaters opened for opera performances during the 1700s. This time period coincides with the rule of Philip V (Bourbon dynasty) and a dominance of Italian opera in Spain. ${ }^{6}$

Theater in Spain, or the comedia ${ }^{7}$, was extremely popular and successful in the seventeenth and eighteenth centuries, and set the stage for opera. Music in Spain was connected to drama early in its development, and this connection would continue in both Spain and the New World. Spanish dramatists utilized engaging plots, entertaining characters, and enchanting themes to embrace their audiences in a story. The Spanish dramatists Lope de Vega and

\footnotetext{
${ }^{3}$ Juan José Carreras, "From Literes to Nebra: Spanish dramatic music between tradition and modernity," in Music in Spain During the Eighteenth Century, eds. Malcolm Boyd and Juan José Carreras (New York, NY: Cambridge University Press, 1998), 7-8.

${ }^{4}$ Julie Anne Sadie, Companion to Baroque Music (New York: Schirmer Music, 1990), 331-332.

${ }^{5}$ Carreras, "From Literes to Nebra: Spanish dramatic music between tradition and modernity," 8-9.

${ }^{6}$ Gerard Béhague, Music in Latin America: An Introduction (Englewood Cliffs, NJ: Prentice-Hall, Inc., 1979), 65, 106.

${ }^{7}$ A comedia was a three-act, tragi-comedic theatrical genre; Louise K. Stein and José Máximo Leza, “Opera, genre, and context in Spain and its American colonies," in The Cambridge Companion to Eighteenth-Century Opera, eds. Anthony R. DelDonna and Pierpaolo Polzonetti (New York, Cambridge Uniersity Press, 2009), 244.
} 
Calderón de la Barca were both important to the development of Spanish opera. ${ }^{8}$ The comedia and opera formed an important connection from the beginning. ${ }^{9}$

Opera in the New World developed in two different ways: one that was aligned with European secular court drama, such as opera in Lima, and the other was a sacred drama used in missions, such as in the Andean region of South America. Early American composers were indebted to either the Church or the state, and this was evident in opera compositions, which praised either one or the other. The loyalty in compositions to the Church or state is in part due to the patronage system. It was instituted in the New World and continued to flourish into the nineteenth century. Both of these opera traditions, secular and sacred, are tied to a European background. ${ }^{10}$

The years from 1810 to 1830 formed a time of national independence throughout Latin America. During this period, the majority of Latin American countries were beginning to fight for independence and were dealing with revolutions. Nationalism in the arts began to develop during the latter part of the nineteenth century. ${ }^{11}$ As individual countries fought for autonomy and the right to govern themselves, they also formed a desire to represent themselves. This search for a national identity and the representation of that identity was expressed in music. Native musical elements were used to express a unique connection to place and lineage, and language was a way to link a work to a Latin American character with either an indigenous or a Spanish ancestry.

Other theatrical and musical forms that were important to the development of Spanish and Latin American opera included autos, villancicos, and tonadillas. An auto is a religious or

\footnotetext{
${ }^{8}$ Gasta, Transatlantic Arias: Early Opera in Spain and the New World, 21-22.

${ }^{9}$ Carreras, "From Literes to Nebra: Spanish dramatic music between tradition and modernity," 9.

${ }^{10}$ Gasta, Transatlantic Arias: Early Opera in Spain and the New World, 16-17, 23-24.

${ }^{11}$ Béhague, Music in Latin America: An Introduction, 96.
} 
allegorical play. Lyric poetry and songs are often included in the performance, and it often ends with a villancico, which is a type of Spanish song. An auto sacramental is an "allegorical religious play on the Eucharist." Pedro Calderón de la Barca wrote several autos. These one-act plays with songs are preceded with a loa, or an overture, and are generally followed by a short skit or dance. ${ }^{12}$ A tonadilla is an intermezzo that appeared between the acts of a play, an opera, or an auto sacramental in Spanish theater of the eighteenth and nineteenth centuries. A tonadilla is at times referred to as a tonadilla escénica because the term was originally used to denote a strophic song that preceded a dance. The tonadilla was popular in both Spain and Latin America. ${ }^{13}$

Zarzuela is a term often confused with Spanish opera, although they are not the same thing. The zarzuela developed from Spanish theater and includes both singing and speech, usually alternating from one to the other, and is sometimes referred to as a Spanish musical theater form. ${ }^{14}$ The development, popularity, and performances of zarzuela were important in the development of opera. Several zarzuela composers took an interest in opera composition, although many found it more difficult and were more successful in zarzuela composition than in composing operas. The zarzuela is recognized as a truly Spanish national art form. It also spread to Latin America and was highly popular there.

Each chapter of this document presents opera in a different country or region: Spain, Mexico, South America, and Central America and the Caribbean. Information is given about the

\footnotetext{
${ }^{12}$ Gasta, Transatlantic Arias: Early Opera in Spain and the New World, 97; Louise K. Stein, “Auto," in Grove Music Online, accessed 21 Mar. 2019, http://www.oxfordmusiconline.com/grovemusic/view/10.1093/gmo/9781561592630.001. 0001/omo-9781561592630-e-0000001566.

${ }^{13}$ Roger Alier, "Tonadilla," in Grove Music Online, accessed 21 Mar. 2019, http://www.oxfordmusiconline.com/grovemusic/view/10.1093/gmo/9781561592630.001.0001/omo9781561592630-e-0000028100.

${ }^{14}$ Gilbert Chase, The Music of Spain (New York: Dover Publications, Inc., 1959), 97-98.
} 
history and development of opera in each region and about the opera compositions and composers connected to that region. Included are compositions and opera composers that were located from the development of opera through the twentieth century. In some cases, there is simply a title of an opera and possibly the name of the composer. In other cases, this research includes the discovery of more detailed information about a work and/or composer and that has been included in this document. Many of the Mexican operas include information about characters and plot, while this is not included for most of the Spanish operas. Some countries have only one composer listed: Chile, Colombia, Venezuela, the Dominican Republic, Guatemala, and Puerto Rico. The type and amount of detail included in this document is based on the available information included in the sources used for this research. 


\section{Chapter 2: Spain}

In Spain, the idea of opera began developing in the seventeenth century, and continued to mature through the following centuries. Philip IV's ascension to the throne in 1621 helped initiate this development. He ordered the construction of a new palace in Madrid, the Buen Retiro. This new monarch's cultural vision included a revival of interest in court theater performances, which all depended on music to some degree. ${ }^{15}$ La selva sin amor, the first opera produced in Spain, was presented in Madrid at the Palacio Real in 1629, within a decade of Philip IV coming to power. The treasured Spanish dramatist Lope de Vega wrote the libretto for this opera. ${ }^{16}$

It was 1660 before another opera was performed at the Spanish court, when two opera collaborations between Juan Hidalgo and Pedro Calderón de la Barca made their appearance. $L a$ púrpura de la rosa and Celos aun del aire matan were recognized as exceptional works. The operas were commissioned to flaunt the grandeur of the court, especially in comparison to similar French celebrations. The operas are clearly native compositions, and display the possibility of creating text and music for performance without being enslaved to foreign ideals. "Hidalgo and Calderón produced a Spanish operatic style (in which the predominant texture is that of the strophic air, even for narrative and dialogue) more than a decade before Lully and Quinault developed a French one."17

Throughout the majority of seventeenth-century Spain, the word "opera" for the musical dramatic form that we currently know, did not exist in the Spanish language. The few operas that

\footnotetext{
${ }^{15}$ Sadie, Companion to Baroque Music, 328.

${ }^{16}$ José Subirá, Historia de la música española e hispanoamericana (Barcelona, Spain: Salvat Editores, S.A., 1953), 341-342.

${ }^{17}$ Sadie, Companion to Baroque Music, 328-329.
} 
existed were labeled fiestas cantadas, or sung parties. The Italian term "opera" was introduced to the Spanish language near the end of the seventeenth century with a fiesta de ópera in $1698 .{ }^{18}$

Music and culture were closely tied to politics and the Spanish monarchy. Philip IV's successor, Charles II, continued the cultural vision started by his predecessor. When the Habsburg rule in Spain began to dissolve and a new monarchy, the Bourbon dynasty, was instituted with Philip V, the new cultural vision showed little interest in purely Spanish culture. The focus on a national cultural identity dissipated and an imported style began to prosper. By the eighteenth century, foreign musicians and composers monopolized music at the Spanish court. The Spanish style still existed during this time, but the music was affected by the infiltration of foreign ideas. ${ }^{19}$

In 1787, an Italian company moved into the Teatro de los Caños del Peral. This established a permanent opera presence in Madrid. ${ }^{20}$ In the nineteenth century, the Teatro Real de Madrid was constructed in the former location of the Teatro de los Caños del Peral, and opened on 7 May 1850. It was built under the command of Isabel II. ${ }^{21}$ In addition to the existence of opera in Madrid, opera developed a strong presence in Barcelona. Other Spanish cities, such as Valencia and Cádiz, also had an interest in opera, but not to the extent of Madrid or Barcelona. ${ }^{22}$

Lyric theater, or Italian opera, was one of the only types of musical performances that was acknowledged in nineteenth-century Spanish society. ${ }^{23}$ Italian opera dominated the Spanish musical scene for the entire century. This posed a challenge for composers that desired to create

\footnotetext{
${ }^{18}$ Subirá, Historia de la música española e hispanoamericana, 350-351.

${ }^{19}$ Sadie, Companion to Baroque Music, 328-332.

${ }^{20}$ Subirá, Historia de la música española e hispanoamericana, 482.

${ }^{21}$ Ibid., 693-694.

${ }^{22}$ Ibid., 484.

${ }^{23}$ Tomás Marco, Spanish Music in the Twentieth Century, trans. Cola Franzen (Cambridge, MA: Harvard University Press, 1993), 13.
} 
a national opera. Many who attempted to do so, failed to succeed in the face of Italian opera. Some composers were successful in creating a Spanish opera and having it produced at Madrid's Teatro Real. However, they dealt with the likelihood that their librettos would be translated to Italian. Challenges surrounding the creation of a national opera, such as translations of librettos to Italian, drove many composers to focus on the composition of zarzuelas. $^{24}$

Nineteenth-century Spanish composers often focused on zarzuelas because it gave them an opportunity to be noticed, but many were also composing national operas, as well as symphonic and chamber music. ${ }^{25}$ In Madrid, there was a desire to establish Spanish opera, and in an attempt to support to this effort, the Spanish Musical Society was founded in $1847 .{ }^{26}$ There was also support for a national opera from the music community, such as the well-known Spanish zarzuela composer Francisco Asenjo Barbieri (1823-1894). He was identified with Spanish traditional and ethnic music, and wrote several popular zarzuelas. He was also outspoken in his approval and encouragement of the idea of a national opera, and because of this, he had an influence on the development of Spanish opera. ${ }^{27}$

The Teatro Real de Madrid closed in 1925, which left the Teatro Liceo of Barcelona as "the only stable institution for presentation of opera in the entire country." ${ }^{28}$ Some national works were produced at the Teatro Liceo early in the century, but over time, the productions became isolated to standard Italian opera repertoire. "The production of opera, almost the only

\footnotetext{
24 Ibid., 13.

25 Ibid., 3-4.

${ }^{26}$ Subirá, Historia de la música española e hispanoamericana, 687.

${ }^{27}$ Chase, The Music of Spain, 141; John Edwin Henken, "Barbieri, Francisco Asenjo," in Grove Music Online, accessed 1 Apr. 2019, http://www.oxfordmusiconline.com/grovemusic/view/10.1093/gmo/9781561592630.001.0001/omo9781561592630-e-0000002006.

${ }^{28}$ Marco, Spanish Music in the Twentieth Century, 13.
} 
form of music that attracted a public, was becoming more and more difficult." ${ }^{29}$ Well into the twentieth century, Spanish opera composition and performance still proved to be challenging.

\section{Spain: Operas and Composers}

La selva sin amor is a one-act opera with a libretto written in $1629^{30}$ by Lope de Vega (1562-1635). Some sources suggest the composer of La selva sin amor is unknown, but more recent sources list Filippo Piccinini (1575-1648) as the composer. ${ }^{31}$ Piccinini composed in the style of the Italian Florentine tradition, and La selva sin amor is often presented as the first "nonnative opera in Spain." The opera was performed in Madrid by members of the Italian delegation brought to Spain by Philip IV. It "featured Italian meter with lines of silvas (seven or eight syllables) and was sung completely in Italian recitative." 32 Other musical parts of the opera include a duet, a trio, and a chorus. ${ }^{33}$ Lope de Vega referred to La selva sin amor as an égloga pastoral, or a pastoral eclogue. ${ }^{34}$ He wrote a dedication, addressed to Don Juan Alonso Enriquez de Cabrera, Admiral of Castile. In the dedication, he expressed the novelty of opera in Spain, "Your Excellency not having seen this Eclogue, which was sung in performance before their Majesties and Highnesses, a new thing in Spain..."35 The plot of the opera follows the problems between two shepherdesses and their lovers, but a happy ending comes through the intervention of Venus and Cupid. ${ }^{36}$ La selva sin amor was successful for its use of scenery and design by

\footnotetext{
${ }^{29}$ Ibid., 13-14.

30 There are some sources that list the year as 1627.

${ }^{31}$ Gasta, Transatlantic Arias: Early Opera in Spain and the New World, 67; Subirá, Historia de la música española e hispanoamericana, 341-342; Chase, The Music of Spain, 96; Sadie, Companion to Baroque Music, 328.

${ }^{32}$ Gasta, Transatlantic Arias: Early Opera in Spain and the New World, 67-68.

${ }^{33}$ Chase, The Music of Spain, 97.

${ }^{34}$ Gasta, Transatlantic Arias: Early Opera in Spain and the New World, 67-68.

${ }^{35}$ Chase, The Music of Spain, 96.

36 Ibid., 97.
} 
Cosimo Lotti, but it did not greatly impact music in Spain. ${ }^{37}$ The opera is important for its place in history as one of the earliest operas tied to a Spanish writer or composer, and for its presentation in Spain.

In 1659, Pedro Calderón de la Barca (1600-1681) wrote two operas: La púrpura de la rosa and Celos aun del aire matan. ${ }^{38}$ La púrpura de la rosa was the first of the two operas, with music composed by Juan Hidalgo (1610-1685). The opera was performed in honor of the marriage between the Spanish Princess María Teresa and the French King Louis XIV. This marriage was part of the Peace of the Pyrenees, or the Treaty of the Pyrenees, that terminated the war between Spain and France. La púrpura de la rosa was presented on 17 January 1660, after the peace treaty was signed in 1659 and before the wedding in June $1660 .{ }^{39}$ The opera premiered at the Coliseo del Buen Retiro, a venue that allowed the performance to be open to a broad public audience. ${ }^{40}$ The music for La púrpura de la rosa included the use of recitative, solos, duets, a quartet, and chorus. It was scored for an orchestra and included dances. ${ }^{41}$

While the music score for La púrpura de la rosa is lost, music does exist for Calderón's second opera, Celos aun del aire matan. Hidalgo also composed the music for this opera, which was performed at the Coliseo del Buen Retiro on 5 December $1660 .{ }^{42}$ It was described in the libretto as a fiesta grande cantada, or a great singing party. ${ }^{43}$ It was not called an opera, because it was presented before the term "opera" was introduced as a musical word in Spanish.

Musicologist José Subirá discovered the music score (voice and bass parts) to the first act of this

\footnotetext{
37 Sadie, Companion to Baroque Music, 328.

${ }^{38}$ Gasta, Transatlantic Arias: Early Opera in Spain and the New World, 72; Subirá, Historia de la música española e hispanoamericana, 345.

${ }^{39}$ Gasta, Transatlantic Arias: Early Opera in Spain and the New World, 72.

${ }^{40}$ Subirá, Historia de la música española e hispanoamericana, 345.

${ }^{41}$ José Subirá, Historia de la música teatral en España (Barcelona, Spain: Editorial Labor, S.A., 1945$), 67$.

${ }^{42}$ Chase, The Music of Spain, 100.

${ }^{43}$ Subirá, Historia de la música teatral en España, 67.
} 
opera while working in the library archives of the Palacio de Liria, the home of the Dukes of Alba in Madrid. ${ }^{44}$

Celos aun del aire matan is a three-act comedy. The plot develops around the nymph Aurora, who has committed the crime of falling in love. The penalty for this crime is death, however, Amor supernaturally intervenes and turns Aurora into a nymph of the air. Following this, the nymph Procris falls in love with Cephalus. Aurora requests that Venus spare Procris, and Jupiter, at the appeal of Venus, turns Procris into a star and Cephalus into a breeze. ${ }^{45}$

Decio y Eraclea was the first opera presented at the Spanish court. It was performed on 25 August 1708 to celebrate the first birthday of Crown Prince Luis, and was dedicated to the first lady-in-waiting, the Princess of Ursins. The opera includes some choruses, but largely follows a pattern of recitatives and da capo arias. The score of the first act has been preserved, although the rest of the score has been lost. The Spanish libretto is anonymous, uses a classical Roman subject, and was based on Silvio Stampiglia's dramma per musica L'Eraclea. ${ }^{46}$

Catalan composer José Durán (ca. 1730-1802) wrote two operas. Antigono was his first opera, which was presented in honor of Queen Analia of Saxony's name day in 1760.

Temistocle, with a text by Metastasio, premiered in Barcelona in 1762. Durán was one of the earliest composers to implement the Italian style in Spain. In addition, he was one of the first composers to present opera in Spain. ${ }^{47}$

Another opera presented in Barcelona was Sesostri (1774) by Catalan Domènec Terradellas (1713-1751). Terradellas was born in Barcelona, then studied in Naples. Most of his

${ }^{44}$ Chase, The Music of Spain, 100; Subirá, Historia de la música teatral en España, 67.

${ }^{45}$ Ibid., 100-101.

${ }^{46}$ Carreras, "From Literes to Nebra: Spanish dramatic music between tradition and modernity," 10-11.

${ }^{47}$ Subirá, Historia de la música española e hispanoamericana, 484; Anna Cazurra, "Duran, Josep," in Grove Music Online, accessed 20 Mar. 2019, http://www.oxfordmusiconline.com/grovemusic/view/10.1093/gmo/9781561592630.001.0001/omo9781561592630-e-0000008374. 
works were composed to texts by Metastasio and Apostolo Zeno, and were performed throughout Italy and London. Other operas that Terradellas composed are Mitridate and Bellerophon. ${ }^{48}$

Valencian composer Vicente Martín y Soler (1756-1806) wrote several operas. His first opera, Ifigenia in Aulide (1781), was instantly popular. He collaborated with Lorenzo Da Ponte on several operas: Il burbero di buon cuore (1786), Una cosa rara (1786), and L'arbore di Diana. Una cosa rara took over Vienna, and was more popular than Mozart's Le Nozze di Figaro, also composed in 1786. In addition to overshadowing Mozart's opera, Una cosa rara is Martín y Soler's most recognized opera today, because Mozart used a theme from this composition in Don Giovanni. ${ }^{49}$ It is heard in the supper scene, in the finale of Act II, when three tunes are played for dinner entertainment. The first of these three melodies is from Act I of Una cosa rara. ${ }^{50}$

Joaquín Espín y Guillén (1812-1881) composed the opera Padilla, o El asedio de Medina (1845). The plot is based on the revolt of the comuneros in 1520, an important event in Spain's history. The entire opera was not produced, but Espín y Guillén did manage to have the first act performed.$^{51}$

Emilio Arrieta (1821-1894) was a Spanish composer that transformed a zarzuela composition into an opera. He took his popular zarzuela, Marina (1855), and expanded it into three acts from two, added arias, and presented it at the Madrid Royal Theater as an opera on 16 March 1871. The opera was musically Italian, with its only Spanish elements appearing in the

\footnotetext{
${ }^{48}$ Chase, The Music of Spain, 138-139.

${ }^{49}$ Ibid., 139; Dorothea Link, "Martín y Soler, (Atanasio Martín Ignacio) Vicente," in Grove Music Online, accessed 16 Mar. 2019, http://www.oxfordmusiconline.com/grovemusic/view/10.1093/gmo/9781561592630.001.0001/omo$9781561592630-\mathrm{e}-0000017943$.

${ }^{50}$ Rodney Bolt, Lorenzo Da Ponte: the Extraordinary Adventures of the Man behind Mozart (London: Bloomsbury Publishing, 2010) 167, 179-180.

${ }^{51}$ Chase, The Music of Spain, 142.
} 
language and the setting. Arrieta also composed the operas Ildegonda (1849) and La conquista de Granada (1850). ${ }^{52}$

Tomás Bretón (1850-1923) was born in Salamanca. He was against Italian musical influence in Spain, which he viewed as disastrous to Spanish nationalism, stating "this Italianism stifles and degrades our art." ${ }^{93}$ He fought for a Spanish national opera and protested Spanish composers' use of Italian librettos. Bretón composed Los amantes de Teruel (1889), a five-act opera. His opera was celebrated throughout Spain, as well as being popular in Vienna and Prague. His second opera, Garín, used a Catalan setting and was successfully performed in Barcelona in 1892. La Dolores (1895) was a three-act opera that received multiple performances in both Madrid and Barcelona, in addition to performances in Milan, Prague, and South America. ${ }^{54}$

Ruperto Chapí (1851-1909) composed several operas, including Roger de Flor, La bruja, Circe, and Margarita la Tornera. He was not highly successful in opera because his works were viewed as "superficial, lacking dramatic power, and weak in characterization." 55

Felipe Pedrell (1841-1922) focused his career on the creation of a national opera. It was a struggle to get most of his works produced, and when they were performed, they were only allowed a few performances. He promoted Spanish music not only through composition, but also through his work as a writer, historian, editor, and teacher. He published a manifesto regarding national opera in 1891, Por nuestra música. His basic principle was "that Spanish opera must go beyond the exterior forms of language, national setting, and borrowings from folk music in order to assimilate and re-create the essence of Spanish spirit as embodied in a synthesis of all its most

\footnotetext{
${ }^{52}$ Ibid., 143.

${ }^{53}$ Ibid., 144.

${ }^{54}$ Ibid., 144.

${ }^{55}$ Ibid., 145.
} 
authentically characteristic manifestations." 56 His opera La Celestina (1904) was based on the Comedia e Calisto y Meliba, which portrays the tragic love story of a young couple. ${ }^{57}$

Isaac Albéniz (1860-1909) was a Catalan composer. He signed a contract to create operas based on librettos by the British banker Francis Burdett Money-Coutts (Lord Latymer). The operas The Magic Opal and Henri Clifford were not successful and he composed some other operas that were left incomplete. Pepita Jiménez, with the libretto based on a novel by Juan Valera, is the only successful product of the collaboration between Albéniz and Money-Coutts. ${ }^{58}$

Amadeo Vives (1871-1932) was from Collbató, but spent most of his life in Madrid. Tomás Marco, Spanish composer and author, referred to Vives as the most important zarzuela composer of the twentieth century. He composed the opera Artús (1897), which was successful in Barcelona. He also wrote other operas such as Eda d'Uriach (1900). ${ }^{59}$

Joaquín Turina (1882-1949) was born in Seville. La sulamita was his first opera, possibly composed as early as 1897 . He moved to Madrid in the hopes of getting his opera performed at the Teatro Real, but he tried unsuccessfully to get it produced. La sulamita uses a biblicallybased theme. Turina composed a second opera, Jardin de oriente (1922), which was performed at the Teatro Real while he was employed there as its choirmaster. ${ }^{60}$

Ricardo Villa (1871-1935) was from Madrid, and he studied both violin and composition. He was a violinist and conductor of the orchestra of the Teatro Real. He composed the opera Raimundo Lulio (1902), along with several zarzuelas. ${ }^{61}$

\footnotetext{
${ }^{56}$ Ibid., 148.

${ }^{57}$ Ibid., 148.

${ }^{58}$ Marco, Spanish Music in the Twentieth Century, 5.

59 Ibid., 95-96.

${ }^{60}$ Ibid., 37- 38; Carlos Gómez Amat, “Turina (Pérez), Joaquín,” in Grove Music Online, accessed 25 Mar. 2019, http://www.oxfordmusiconline.com/grovemusic/view/10.1093/gmo/9781561592630.001.0001/omo9781561592630-e-0000028603.

${ }^{61}$ Marco, Spanish Music in the Twentieth Century, 83; Chase, The Music of Spain, 145.
} 
Joan Manén (1833-1971) was a composer from Barcelona. In 1902, his opera Acté was performed at the Liceo in Barcelona, and the next year, Juana de Nápoles was produced at the Liceo. His other opera compositions include Heros, Medea, Nerón, Acté (a different version than the one presented at the Liceo), and Soledad (1952). ${ }^{62}$

Enric Morera (1865-1942) was born in Barcelona, his family moved to Argentina when he was two years old, and he later moved back to Europe. He composed several operas: La devoción de la Cruz (1904), Emporium (1906), Bruniselda (1908), Tasarba, El mestre (1921), and Don Joan de Serrallonga (1921). ${ }^{63}$

Manuel de Falla (1876-1946) was born in Cádiz, a city that had a genuine enthusiasm for music, and held regular performances of operas and zarzuelas. La vida breve (1905) was his first major important work. The inspiration for the opera came from a poem by Carlos Fernández Shaw, and Fernández Shaw developed the poem into a libretto for de Falla. La vida breve won a competition by the Academia de Bellas Artes for best Spanish opera in 1905, however the opera was not produced due to disinterest in staging Spanish operas. Debussy and Dukas expressed an interest in de Falla's opera, and it was eventually produced in France. The opera was wellreceived and after its performance in Paris, it was translated into French and presented in Nice. La vida breve became known in Spain through its success in France. ${ }^{64}$ The opera had an orchestrated score and primarily used imaginary folklore, but also included authentic dances and a flamenco scene. After La vida breve, de Falla did not continue his pursuit of creating a national opera. $^{65}$

\footnotetext{
${ }^{62}$ Marco, Spanish Music in the Twentieth Century, 60.

${ }^{63}$ Ibid., 75-76.

${ }^{64}$ Ibid., 19-20.

${ }^{65}$ Ibid., 20, 30.
} 
José María Usandizaga (1881-1915) was a zarzuela composer, born in San Sebastián. He composed a Basque opera, Mendi-Mendiyan (1910). It had a successful premiere and has remained in the Spanish opera repertoire. ${ }^{66}$

Jaime Pahissa (1880-1969) was from Barcelona and later moved to Argentina. He composed several operas. La prisión de Lérida (1906) was later changed into La princesa Margarida (1928). Pahissa’s other operas include: Canigó (1910), Gala Placidia (1913), La morisca (1919), Marianela (1923), Angelica (1938), Don Gil de las calzas verdes (1955), and Tragicomedia de Calixto y Melibea (1956). ${ }^{67}$

Conrado del Campo (1878-1953) was born in Madrid, and in 1889 began studies at the Madrid Conservatory. His first attempt at opera was El final de Don Alvaro (1910) with a libretto by Carlos Fernández Shaw, which was performed at the Teatro Real, as was another of del Campo's operas, La tragedia del beso (1911). La tragedia del beso, a one-act opera, also with a libretto by Fernández Shaw, won the Premio Nacional de Bellas Artes in 1912, but was not produced until 1915. Del Campo composed a grand opera with a libretto by Tomás Borrás, El Avapiés (1918). El Avapiés painted a picture of 1800s Madrid and was aimed at entertaining a broad audience. Fantochines (1922) is a chamber opera that del Campo wrote with a libretto by Borrás. It is his only opera composition that is still produced. His opera Lola, la piconera (1949) with a libretto by José María Pemán was presented at Barcelona’s Teatro del Liceo. Some of del Campo's operas were not produced, including La malquerida (1925) with a libretto by Federico Romero and Guillermo Fernández Shaw, based on Jacinto Benavente's play of the same name. ${ }^{68}$

\footnotetext{
66 Ibid., 93.

67 Ibid., 66-67.

${ }^{68}$ Ibid., 31-34.
} 
Jesús Guridi (1886-1961) was born to a family of musicians in Vitoria. He tried to write opera, but more specifically than Spanish opera, he attempted to write Basque opera. He composed two successful operas, but then restricted his compositions to zarzuela. The first opera was Mirentxu (1910), with a libretto by Alredo Echave. Guridi initially wrote Mirentxu as a zarzuela and then converted it to an opera in 1947 . He was asked to write this opera by the Sociedad Coral. The music was derived from popular melodies and structured after Bohemian and Russian composers of the nineteenth century. His second opera, Amaya (1920), with a libretto by José María Arroita Jáuregui, was based on a novel by Francisco Navarro Villoslada. Amaya was successfully produced in several countries and Tomás Marco writes that it is "one of the best Spanish operas of the century." 69

Vicente Arregui (1871-1925) was born in Madrid, although his family was from Navarre. He composed several operas. His opera, Yolanda (1910), won the Concurso Nacional of 1911, but it was not staged until 1923 when it was given two performances at the Teatro Real. He composed three unproduced operas: El cuento de Barba Azul, La Maya, and La Madona. ${ }^{70}$

Andrés Gaos (1874-1959) was from the Galicia region. He studied in Spain, France, and Belgium, and lived for several years in Argentina. He was a concert violinist and wrote the opera Amor vedado (1914)..$^{71}$

Francisco Calés Pina (1886-1957) was born in Zaragoza and studied in Madrid. He was a professor of choral and instrumental music at the Madrid Conservatory. He wrote two unpublished operas: Las sombras del bosque (1914) and El miserere de las montañas (1924). ${ }^{72}$

\footnotetext{
${ }^{69}$ Ibid., 47-49.

${ }^{70}$ Ibid., 57.

${ }^{71}$ Ibid., 81-82.

${ }^{72}$ Ibid., 60.
} 
María Rodrigo (1888-1967), from Madrid, was one of the only female composers of her generation. She composed Becqueriana, a popular opera at the time it was written, with text by the Quintero brothers. Lesser-known operas she composed include: Canción de amor, Diana cazadora, La romería del Rocío, La flor de la vida. ${ }^{73}$

Catalan composer Enrique Granados (1867-1916) first received recognition for his zarzuela compositions, but also composed in other genres, including opera. He composed a collection of piano pieces titled Goyescas, that he premiered in Barcelona in 1911. The work was highly successful and the Paris Opera recommended that Granados compose an opera based on the piano compositions. Granados did that, but despite enthusiasm in Paris for the opera, the start of World War I hindered its staging. However, the New York Metropolitan Opera accepted and produced the opera. Goyescas premiered in New York City on 26 January 1916, "with the composer himself at the piano." 74

Julio Gómez (1886-1973) was a native of Madrid and, from 1909 to 1913, he was arranger for the Teatro Real. He composed several operas. His first opera, Himno de amor (1917), with a libretto by Sinesio Delgado, was a comic grand opera. He wrote El pilar de la victoria (1944) with a libretto based on text by Manuel Machado. He finished writing the opera Mar de invierno (1956) with a libretto by Matilde Muñoz, but it was never staged. Gómez also composed two chamber operas, El pelele (1925) and Los dengues (1927), both with librettos by Cipriano Rivas Cherif. ${ }^{75}$

José María Franco Bordóns (1894-1971) was born in Iruña and attended the Madrid Conservatory. He was a popular and widely recognized pianist, and occasionally conducted the

\footnotetext{
${ }^{73}$ Ibid., 65 .

${ }^{74}$ Ibid., 7.

${ }^{75}$ Ibid., 45.
} 
orchestra of the opera company Angeles Ottein, as well as other orchestras. He was a violinist and composed the opera 1833 in $1922 .^{76}$

Zarzuela composer, Federico Moreno Torroba (1891-1982) was born in Madrid to a family from Navarre. His great success in zarzuela composition overshadowed the rest of his compositional output. He wrote the operas La virgen de Mayo (1924) and El poeta (1979). La virgen de Mayo was the last opera to be presented in the Teatro Real before it closed in $1925 .^{77}$

Facundo de la Viña (1876-1952) was born in Gijón and studied at the Madrid

Conservatory. He composed two operas that were not staged: Almas muertas and La montaraza de Grandes. He also wrote two successful operas: La princesa flor de roble and La espigadora $(1927) .^{78}$

Eduard Toldrá (1895-1962) was from Vilanova y Geltrú and was recognized as a child violin prodigy. He composed the opera El giravolt de maig (1928), which is still included in contemporary repertoire. ${ }^{79}$

Gregorio Baudot (1884-1938) was born in Colmenar Viejo. He later lived in El Ferrol in the region of Galicia and came to be recognized as a Galician composer. He was a flutist, the director of Spain's navy band, and composed the Galician opera Cantuxa in $1928 .{ }^{80}$

Salvador Bacarisse (1898-1963) was born in Madrid, exiled, and later settled in Paris. He studied with Conrado del Campo, and was interested in impressionism, neoclassicism, and neoromanticism. He wrote the operas Charlot (1933) and Fuenteovejuna (1962). ${ }^{81}$

\footnotetext{
${ }^{76}$ Ibid., 65-66.

${ }^{77}$ Ibid., 98-99, 112; The Teatro Real reopened in 1966.

${ }^{78}$ Ibid., 59.

${ }^{79}$ Ibid., 77.

${ }^{80}$ Ibid., 82.

${ }^{81}$ Ibid., 108-109.
} 
Matilde Salvador (1918-2007) was born in Castellón. She studied composition with her husband, composer Vicente Asencio. Salvador wrote for a variety of instruments and in several genres, but is primarily known for her song compositions. She composed two operas, La filla del rey barbut (1943) and Vinatea (1973). ${ }^{82}$

Carlos Suriñach (1915-1997) was born in Barcelona, but later moved to Paris and then to the United States. He directed the Teatro del Liceo in Barcelona for several years, and was interested in Catalan nationalism and flamenco style. He wrote El mozo que casó con mujer $\operatorname{brava}(1948) .{ }^{83}$

Jaime Mas Porcel (1909-1993) was from Las Palmas, and worked as both a pianist and as a teacher in Alicante. He found his musical inspiration in the area of the Spanish Levant, a region along the eastern coast of Spain. He composed the opera El castell dirós i non tornarás (1952). ${ }^{84}$

Antonio Massana (1890-1966) was born in Barcelona and later moved to Brazil. He studied in Spain and Italy, and worked as an organist in the church of the Jesuits while in Barcelona. He wrote two operas, Nuredduna (1948) and Canigó (1953). ${ }^{85}$

Manuel Palau (1893-1967) was a native of Alfara del Patriarca. He studied in Valencia, Paris, and Berlin. His inspiration came from the region of the Spanish Levant, and he wrote the opera Moros $(1953-1956){ }^{86}$

Roberto Gerhard (1896-1970) had Swiss ancestry, was a native of Valls (Tarragona), and later moved to England. Twenty years after moving to England, he took on British citizenship, but he still considered himself Spanish and continued to align his compositions with a Spanish

\footnotetext{
${ }^{82}$ Ibid., 138.

${ }^{83}$ Ibid., 135.

${ }^{84}$ Ibid., 140.

${ }^{85}$ Ibid., 87.

${ }^{86}$ Ibid., 79.
} 
style. He studied with Granados, Pedrell, and Schoenberg, and composed the opera La dueña using Spanish nationalist features. ${ }^{87}$

Victorino Echevarría (1898-1965) was from Becerril de Campos (Palencia). He studied in Madrid, as well as with Paul Hindemith, and was the chair of harmony at the Madrid Conservatory. He composed the chamber opera El anillo de Polícrates. ${ }^{88}$

Angel Arteaga (1928-1984) was from Campo de Criptana (La Mancha) and studied in both Madrid and Munich. He was known for composing film scores and also had a career in teaching. He wrote two short operas, both derived from texts by Ramón Gómez de la Serna: $L a$ mona de imitación (1958) and El terrible entrevistador (1960). ${ }^{89}$

Josep María Mestres-Quadreny (b. 1929), of Manresa, studied science and worked as a chemist. He was a member of the Círculo Manuel de Falla, and was interested in electronic music and aleatoric techniques. He wrote the opera El ganxo (1959). ${ }^{90}$

Josep Soler (b. 1935), from Barcelona, had a compositional style that included the use of twelve-tone technique. He composed Agammenon (1960, revised 1973), and it won a prize in 1964 although it was not produced. He also composed the opera Edipo y Yocasta (1972), which is recognized in a concert version..$^{91}$

Xavier Montsalvatge (1912-2002), of Gerona, wrote El gato con botas (1948) and Una voz en off (1962). ${ }^{92}$

Francisco Escudero (1912-2002) was born in San Sebastián, and was a nationalist Basque composer. He studied in Spain, France, and Germany. He composed Zigor in 1963, and

\footnotetext{
${ }^{87}$ Ibid., 104.

${ }^{88}$ Ibid., 136.

${ }^{89}$ Ibid., 192-193.

${ }^{90}$ Ibid., 174.

${ }^{91}$ Ibid., 179.

${ }^{92}$ Ibid., 143-145.
} 
composed a second opera, Gernika, in 1986. In both operas, he used material based on Basque folklore without directly referencing the folklore. ${ }^{93}$

Ramón Barce (1928-2008), from Madrid, was primarily a self-taught musician. He was interested in new music, expressionism, and serialism. He used aleatoric techniques in some of his compositions, and worked as a translator of Schoenberg's writings. He composed an opera based on his own libretto, Los bárbaros (1965-1973), but it was never performed. ${ }^{94}$

Leonardo Balada (b. 1933) was born in Barcelona, but later moved to the United States where he studied at the Juilliard School in New York. He worked in the United States as a professor and professional musician while maintaining a connection with the Spanish musical world. ${ }^{95}$ He composed the chamber opera Hangman, Hangman! (1982), set in the American Old West, to his own libretto in English, Spanish, and Catalan versions. The opera was commissioned and premiered at the Barcelona International Festival. The Town of Greed (1997) is a sequel to Hangman, Hangman!. It is a chamber opera based on a book by A. Midani and Balada, with the libretto written by Balada in English, Spanish, and Catalan. Its world premiere took place at the Teatro de la Zarzuela in Madrid in September 2007. ${ }^{96}$

Balada's opera Zapata was written in 1984 to an English libretto. It is a two-act grand opera, based on the life and death of Emiliano Zapata, a Mexican revolutionary. It was commissioned by San Diego Opera. Christopher Columbus (1986) is a two-act grand opera. It was commissioned by the Spanish government to celebrate the 500 -year anniversary of the arrival of the Spanish to the Americas. The libretto was written by Antonio Gala in Spanish. The

\footnotetext{
${ }^{93}$ Ibid., 152-153; Jon Bagüés, "Escudero, Francisco," in Grove Music Online, accessed 20 Mar. 2019, http://www.oxfordmusiconline.com/grovemusic/view/10.1093/gmo/9781561592630.001.0001/omo9781561592630-e-0000008979.

${ }_{94}^{4}$ Marco, Spanish Music in the Twentieth Century, 171-173.

95 Ibid., 180-181.

${ }^{96}$ Leonardo Balada, "Leonardo Balada: Opera," accessed 19 Apr. 2019, https://www.andrew.cmu.edu/user/balada/compositions_opera.htm.
} 
Death of Columbus (1996) is a sequel to Christopher Columbus. The plot begins with the return of Columbus to Spain after his trip to the Americas, and ends with his death. The composer himself wrote the libretto for this two-act grand opera. ${ }^{97}$

Luis de Pablo (b. 1930) is from Bilbao. His first opera, Kiu (1981), was based on text by Alfonso Vallejo. ${ }^{98}$ He composed three additional operas: El viajero indiscreto (1984-1988), La madre invita a comer (1992), and La señorita Cristina (1997-1999). ${ }^{99}$

\footnotetext{
${ }^{97}$ Ibid.

${ }^{98}$ Ibid., 163, 167.

${ }^{99}$ Christiane Heine, "Pablo (Costales), Luis de," in Grove Music Online, accessed 20 Mar. 2019, http://www.oxfordmusiconline.com/grovemusic/view/10.1093/gmo/9781561592630.001.0001/omo9781561592630-e-0000020636.
} 


\section{Chapter 3: Mexico}

The origins of opera in Mexico, as well as in the rest of Latin America, began with religious lyric drama. Throughout the sixteenth and seventeenth centuries, the main purpose of dramatic performance was to support the Church. Popular dramatic forms of the time were autos sacramentales, coloquios, and entremés. Autos sacramentales, or religious plays set to music, were the most widely used drama. A more secular dramatic form developed in the late seventeenth century when the colonies were exposed to the works of Lope de Vega and Pedro Calderón de la Barca, as well as to the zarzuela. ${ }^{100}$

Initially, secular dramatic works in Mexico were performed as court theater. However, as the eighteenth century progressed, new theaters and opera houses appeared in larger cities, providing more variety in performance venues. The Teatro Coliseo was opened in 1670 and performances were held there until 1722, when it burned in a fire. In 1735, the Coliseo Nuevo opened. ${ }^{101}$ However, the Coliseo Nuevo suffered bankruptcy in 1816, during the time of the Revolution. It had been presenting Spanish-based theatrical forms such as the zarzuela and tonadilla. Other than Zumaya's La parténope, Mexican operas were not produced until after independence was gained in $1821 .{ }^{102}$

The first known full opera production in Mexico was La parténope, an opera by Manuel de Zumaya. It was presented in 1711 at the viceregal palace. ${ }^{103}$ Although this initiated opera in Mexico, it would not become a standard genre until the middle of the nineteenth century. Tonadillas, sainetes, and zarzuelas prevailed in popularity until that time. When Italian opera

\footnotetext{
${ }^{100}$ Béhague, Music in Latin America: An Introduction, 60.

101 Ibid., 60.

102 Béhague, Music in Latin America: An Introduction, 97; Stevenson, Music in Mexico, 175.

${ }^{103}$ Béhague, Music in Latin America: An Introduction, 16.
} 
was presented in this era, it was often transformed into the form of a zarzuela, interspersing spoken dialogue with the music. ${ }^{104}$ This was done with the Cimarosa's El filósofo burlando in 1805 , as well as other operas that were presented during this era. ${ }^{105}$

Two major factors in the creation of opera were teaching and example. ${ }^{106} \mathrm{~A}$ respected Mexican composer during the revolutionary time was José Mariano Elízaga (1786-1842). While he did not compose opera, he was known as the "father of Mexican music" because he was influential in establishing music education and encouraging music in society. ${ }^{107}$ Elízaga's work to promote musical literacy in Mexico impacted musicians, and had an effect on the composition of Mexican works, including opera. He helped initiate the teaching that was needed for growth in compositions. The second factor that contributed to opera composition, the examples of opera, came from exposure to performances of foreign opera in Mexico.

Manuel García was a native of Seville that promoted Italian opera in several countries. ${ }^{108}$ In 1825, his company successfully introduced foreign-language opera in New York. In Mexico, he promoted opera sung in Italian, and in 1831, the Teatro Principal initiated an annual season of Italian opera. This inspired local composers to create opera in an Italian style. Some recognized composers that started working in this fashion were Luis Baca, Cenobio Paniagua, and Melesio Morales, who will be discussed later. ${ }^{109}$ While García's work led to an increase in opera performances in Italian, it was detrimental to opera in Spanish. ${ }^{110}$ Italian opera became the desired operatic entertainment, leaving Spanish opera as a less acceptable operatic form.

\footnotetext{
104 Ibid., 60.

105 Robert Stevenson, Music in Mexico (New York: Thomas Y.Crowell Company, 1952), 174.

106 Jesús Romero, La ópera en Yucatan (México D.F., Ediciones Guión de América, 1947), 48.

${ }_{107}$ Béhague, Music in Latin America: An Introduction, 97; Leslie Bethell, A Cultural History of Latin America: Literature, Music and the Visual Arts in the $19^{\text {th }}$ and $20^{\text {th }}$ Centuries (New York, NY, Cambridge University Press, 1998), 18.

${ }^{108}$ Stevenson, Music in Mexico, 192.

${ }_{109}$ Béhague, Music in Latin America: An Introduction, 97-98.

${ }^{110}$ Romero, La ópera en Yucatan, 50.
} 
Theater owners were fundamental in selecting repertoire for each opera season, and therefor controlled which operas were produced. The foreign opera companies that performed in Mexico specialized in performances of Italian opera, as well as some French, English, and German operas. Italian operas were the primary choice for performance, and because of that, were the most frequently produced. The production of operas composed by Mexican composers did not catch the attention of theater owners. ${ }^{111}$ This made it more difficult to have a national opera produced and discouraged potential opera composers away from anything other than a traditional Italian language and style of opera.

Moving into the twentieth century, Porfirio Díaz (the President of Mexico) and the Mexican government supported musical performances, including seasons established by opera companies in various theaters of Mexico City. The largest theater was the Gran Teatro Nacional, however it was demolished in 1901. This forced all productions to move to other local theaters such as the Arbeu, Renacimiento (later renamed the Virginia Fábregas), Circo Teatro Orrin, and the Conservatory theater. ${ }^{112}$

Mexico's musical culture was impacted by the Mexican Revolution (1910-1920). In this period and moving forward, musical nationalism that focused on indigenous sources was a focal point in composition. ${ }^{113}$ In 1910, the Sociedad Impulsora de Ópera Nacional was formed, with the goal of representing Mexican operas. The company debuted at the Teatro Arbeu on 27 August 1910 with Nicolás Bravo by Rafael J. Tello, which was presented as part of a celebration to commemorate the centennial of independence. ${ }^{114}$ The struggle for identity and for expression

\footnotetext{
111 Aurelio Tello, La música en México: Panorama del siglo XX (México D.F., Fondo de Cultura Económica Consejo Nacional para la Cultura y Las Artes, 2010), 614-615.

112 Tello, La música en México: Panorama del siglo XX, 614.

113 Béhague, Music in Latin America: An Introduction, 125.

114 Tello, La música en México: Panorama del siglo XX, 618.
} 
as an independent nation, contributed to a desire for the creation and performance of a national opera.

In 1920, the music faculty at the University of Mexico solicited Mexican composers to participate in a competition to write opera librettos. The winners would receive a prize and would have their librettos set to music by a national opera company, however, the competition was unsuccessful. Another competition was attempted in October 1922, when the newspaper El Universal sponsored a contest for Mexican opera. There were only three participants: Elvira (composer unknown), Fernando del Castillo’s Cíhuatl, and José F. Vásquez’s Citlali. Vásquez won the competition with Citlali. ${ }^{115}$

For the majority of the operas that were composed in Mexico, the scores have either been lost or are carefully protected by the descendants of the composers. Many Mexican opera compositions tend to demonstrate evidence of Italian influence, however the 1930s brought more interest in nationalism in compositions. The Palacio de Bellas Artes opened in the 1930s, eventually becoming the established theater for opera performances, with a particular focus on Italian opera. A civil association that focused on opera, Ópera Nacional, was established in 1943. This company presented annual seasons of opera performances in the Palacio de Bellas Artes until 1954. ${ }^{116}$

The presentation of Mexican operas noticeably declined in the 1950s. The 1960s and 1970s brought change and experimentation in musical compositions of all types. However, production in opera was still diminishing through this time. It would be the 1980s before passion for the creation of Mexican opera would grow again, leading to an increase in works by Mexican

\footnotetext{
115 Ibid., 622-623.

${ }^{116}$ Ibid., 626, 628-629.
} 
composers. A variety of styles and designs characterized Mexican opera compositions at the end of the twentieth century, including traditional techniques and atonality. ${ }^{117}$

\section{Mexico: Operas and Composers}

Manuel de Zumaya (ca. 1678-1755) was the first chapelmaster born in Mexico. He composed several works, including the opera La parténope, with a libretto written by Silvio Stempiglia. The opera was presented on 1 May 1711 at the viceregal palace. It is believed that the music likely conformed to an Italian style because the new viceroy, the Duke of Linares who was partial to Italian opera, was fond of La parténope. The music score did not survive, but the libretto does still exist, and is printed in both Spanish and Italian. It was written in three acts, with seven characters including two rival princesses. ${ }^{118}$

One of the earliest Mexican operas was México libre. This one-act opera was composed by José María Bustamante (1777-1861) to a libretto by Francisco Luis Ortega, and premiered in the Teatro Principal on 27 October 1821. Other early Mexican opera compositions include Reinaldo y Elina o la sacerdote peruana by Manuel Covarrubias and La vendetta by Rafael Palacios. $^{119}$

Luis Baca (1826-1855), from Durango, was the first native Mexican opera composer after Mexican independence was won (1810). He studied in both Mexico and France, and composed two operas while abroad in Paris: Leonor, with a libretto by Carlo Bozzeti, and Giovanni di

\footnotetext{
117 Ibid., 631, 633, 636, 641.

118 Béhague, Music in Latin America: An Introduction, 15-16, 60.

119 Romero, La ópera en Yucatan, 48-50.
} 
Castiglia, with a libretto by Tamístocles Solera. Unfortunately neither of the operas were produced. ${ }^{120}$

Cenobio Paniagua y Vázquez (1821-1882), born in Tlalpujahua, a village in the state of Michoacán, was an important Mexican opera composer, organist, violinist, and conductor. His opera Catalina di Guisa, with a libretto by Félix Romani, opened on 19 September 1859 in the Teatro Nacional. ${ }^{121}$ Critics of this opera suggested that the only Mexican feature about the opera was the composer himself. ${ }^{122}$ His one-act opera, Una riña de aguadores, premiered 10 November 1859. Pietro d'Avano, his third opera, was presented at the Teatro Nacional on 5 May 1863. He composed one more opera, El patria, with a libretto by Vicente Riva Palacio, but this opera was never produced. ${ }^{123}$

Paniagua y Vázquez had several students that desired to compose in the Italian style. Octaviano Valle wrote Clotilde de Conzenza, which premiered in the Teatro Nacional on 19 July 1863. Mateo Torres Serrato composed I Due Foscari y Fidelio. Leonardo Canales composed Pirro de Aragón, which premiered in the Teatro Nacional on 12 July1864. Miguel Meneses wrote Agorante Rey de Nubia, which premiered at the Teatro Nacional in 1864, and was produced for the birthdays of the Archdukes Maximillian and Charlotte. Meneses composed several other operas as well: Atala, El hada del lago, Judith, and Luisa de Lavalliere. Ramón Vega composed El grito de dolores, with a libretto by Juan A. Mateos. He also composed the

\footnotetext{
${ }^{120}$ Romero, La ópera en Yucatan, 50; Stevenson, Music in Mexico, 195; Miguel Ficher, Martha Furman Schleifer, and John M. Furman, Latin American Classical Composers: A Biographical Dictionary (Lanham, Maryland, Scarecrow Press, Inc., 2002), 55.

${ }^{121}$ Romero, La ópera en Yucatan, 52; Ficher, Furman Schleifer, and Furman, Latin American Classical Composers: A Biographical Dictionary, 312.

${ }^{122}$ Bethell, A Cultural History of Latin America: Literature, Music and the Visual Arts in the $19^{\text {th }}$ and $20^{\text {th }}$ Centuries, 73.

${ }^{123}$ Romero, La ópera en Yucatan, 52.
} 
operas La Reina de León and Adelaida y Comingo. Antonio de María y Campos wrote two operas: Olga de Monterrojo and El Rey Domingo I. ${ }^{124}$

Melesio Morales (1838-1908) was a Mexican composer and teacher that studied in Mexico and Italy, and composed several operas. Romeo y Julieta premiered at the Teatro Nacional on 27 January 1863, and was directed by the composer himself. ${ }^{125}$ His opera Ildegonda (1866) was presented by an Italian opera company. Other operas by Morales include Gino Corsini (1877), Carlomagno, La tempestad, Asuero (incomplete), and Cleopatra (1891). ${ }^{126}$ Cleopatra was the only opera that was well-received. ${ }^{127}$ Morales last opera was Anita, a one-act opera that was composed to a libretto in Italian by Enrico Golisciani. The plot follows the tragic romance between Anita and Gastón D’Auvray during the French invasion of Mexico. It was rehearsed for performance in 1903, but it was cancelled at the last minute for unknown reasons. ${ }^{128}$

Julio M. Morales and Miguel Planas were both students of Melesio Morales. Julio M. Morales, the son of Melesio Morales, was also an opera composer. He wrote Colón en Santo Domingo, which premiered at the Teatro Nacional on 21 October $1892 .{ }^{129}$ Miguel Planas composed Don Quijote en la venta encantada, which premiered on 5 May 1871 in the Teatro Nacional. He also wrote Felipe IV. ${ }^{130}$

\footnotetext{
${ }^{124}$ Ibid., 52, 70.

${ }^{125}$ Romero, La ópera en Yucatan, 53; Ficher, Furman Schleifer, and Furman, Latin American Classical Composers: A Biographical Dictionary, 283; Mayer-Serra panorama 47

${ }^{126}$ Romero, La ópera en Yucatan, 55-57; Ficher, Furman Schleifer, and Furman, Latin American Classical Composers: A Biographical Dictionary, 283; Subirá, Historia de la música española e hispanoamericana, 950.

${ }^{127}$ Stevenson, Music in Mexico, 199.

${ }_{128}$ Tello, La música en México: Panorama del siglo XX, 617.

${ }^{129}$ Romero, La ópera en Yucatan, 57.

${ }^{130}$ Ibid., 57.
} 
Felipe Villanueva (1863-1893) was a Mexican pianist and composer. He was born in Santa Cruz Tecamac, studied at various schools in Mexico, and composed the comic opera Keofar. ${ }^{131}$

Fernando González Peña was a singer and composer that sang the leading tenor role of Daniel in Tello's opera Due amori. ${ }^{132}$ He also composed the opera Cuauhtémoc. ${ }^{133}$

Estanislao Mejía Castro (1882-1967), from San Idelfonso Hueyotlipan in Tlaxcala, was a Mexican composer and teacher. He studied harmony with Rafael J. Tello; counterpoint, fugue, and instrumentation with Gustavo Campa; and organ with Father José Guadalupe Velázquez. Mejía Castro composed the opera Edith. ${ }^{134}$

Manuel María Ponce (1862-1938) was a Mexican composer and pianist from Fresnillo in the state of Zacatecas. He took lessons in composition, orchestration, and piano, and studied in Mexico, as well as in Italy, Germany, and France. He composed the opera El patio florido. ${ }^{135}$

Antonio Gómezanda (1894-1961) was born in Lagos in the state of Jalisco. He took lessons in piano with Manuel Ponce, and also studied composition and conducting in Mexico and Germany. He composed the opera La virgen de San Juan. ${ }^{136}$

\footnotetext{
${ }^{131}$ Romero, La ópera en Yucatan, 58; Ficher, Furman Schleifer, and Furman, Latin American Classical Composers: A Biographical Dictionary, 436; Tello, La música en México: Panorama del siglo XX, 189.

${ }^{132}$ Tello, La música en México: Panorama del siglo XX, 620.

${ }^{133}$ Romero, La ópera en Yucatan, 58.

${ }^{134}$ Romero, La ópera en Yucatan, 58; Ficher, Furman Schleifer, and Furman, Latin American Classical Composers: A Biographical Dictionary, 269.

${ }^{135}$ Bethell, A Cultural History of Latin America: Literature, Music and the Visual Arts in the $19^{\text {th }}$ and $20^{\text {th }}$ Centuries, 76; Ficher, Furman Schleifer, and Furman, Latin American Classical Composers: A Biographical Dictionary, 330; Romero, La ópera en Yucatan, 59.

${ }^{136}$ Romero, La ópera en Yucatan, 59; Ficher, Furman Schleifer, and Furman, Latin American Classical Composers: A Biographical Dictionary, 184.
} 
Aniceto Ortega del Villar (1825-1875) was a composer, pianist, and physician, born in Tulacingo in Hidalgo, Mexico. He composed Guatimotzín, which premiered on 13 September 1871. The opera presents a story of the last days of the Aztecs. ${ }^{137}$

Ricalde Moguel composed El conde de Ucanor, Un amor de Hernán Cortés, Gil González de Avila, El juicio final, and Anita y Lilia o secretos de un padre. Moguel initiated opera in the Yucatan peninsula. ${ }^{138}$

Cornelio Cárdenas Samada composed the music and wrote the librettos for Escenas Itzalanas, an opera in one act; Chichen Itzá, an opera in four acts; and Ya yaax can, an opera in three acts. ${ }^{139}$

Ricardo Castro Herrera (1864-1907) was a Mexican pianist and composer, born in Durango. ${ }^{140}$ His opera Atzimba opened 20 January 1900. It appeared again on 11 November 1901, at the Teatro Arbeu, to replace the production of Campa's opera, El rey poeta. Atzimba was written in two acts and used a French libretto written by Alberto Michel. It is set in Pátzcuaro in 1552, and the plot follows a love story between Atzimba, an indigenous princess, and Jorge de Villadiego, a Spanish capitan. La leyenda de Rudel, another opera composed by Castro, was presented on 1 November 1906 in the Teatro Arbeu. Alberto Michel wrote the threeact French libretto for La leyenda de Rudel. It is set in the Middle Ages, in a land between Provenza and Palestine, and tells the story of the famous troubadour Jaufré Rudel. ${ }^{141}$ Castro also composed the opera Con Juan de Austria. ${ }^{142}$

\footnotetext{
${ }^{137}$ Romero, La ópera en Yucatan, 70; Bethell, A Cultural History of Latin America: Literature, Music and the Visual Arts in the $19^{\text {th }}$ and $20^{\text {th }}$ Centuries, 73; Ficher, Furman Schleifer, and Furman, Latin American Classical Composers: A Biographical Dictionary, 305.

${ }_{138}$ Romero, La ópera en Yucatan, 70, 73.

${ }^{139}$ Ibid., 78.

${ }^{140}$ Ficher, Furman Schleifer, and Furman, Latin American Classical Composers: A Biographical Dictionary, 105.

${ }^{141}$ Tello, La música en México: Panorama del siglo XX, 616-618.

142 Romero, La ópera en Yucatan, 58.
} 
Gustavo E. Campa (1863-1934) was a composer and teacher, born in Mexico City. El rey poeta premiered 9 November 1901 in the Teatro Principal. The libretto was written by a French writer, Alberto Michel. It is a one-act opera that shares the life story of the emperor Nezahualcóyotl. The opera did not have a successful opening. ${ }^{143}$

Ernesto Elorduy Medina (1854-1913) was a pianist and composer, born in Zacatecas. He studied in Mexico, Germany, and France. Elorduy's opera, Zulema, opened in the Teatro del Conservatorio on 22 January 1902. It was composed in one act, with a libretto in Spanish by Rubén M. Campos. It was a novelty that the opera was sung in Spanish because, at that time, Mexican musicians generally preferred to perform music in Italian or French. The opera tells the story of Zulema. She is favored in Pashá Selim's harem, although she is in love with a slave, Muley, who is actually a kidnapped Arabic prince. When Selim discovers the two, they are both sold as slaves. Muley is bought and granted his freedom, and then he looks for Zulema to rescue her and take her with him. Zulema was successful and returned to the theater multiple times. ${ }^{144}$

Rafael J. Tello (1872-1946) was a composer, teacher, and pianist from Mexico City that composed several operas. ${ }^{145}$ Nicolás Bravo opened to a full house at the Teatro Arbeu on 17 August 1910, with an Italian-style overture to begin the opera. The libretto was written by Ignacio Mariscal, and was derived from his drama Don Nicolás Bravo o Clemencia mexicana. The story wavered between General Nicolás Bravo's life and the love story between the creole María and Spanish Captain Sánchez, a prisoner of Bravo. Due amori, with an Italian libretto by Eduardo Trucco, premiered on 31 December 1915. The story takes place at the beginning of the Christian era, in the neighborhoods surrounding Jerusalem. Elena, a shepherdess, is in love with

\footnotetext{
143 Tello, La música en México: Panorama del siglo XX, 615; Ficher, Furman Schleifer, and Furman, Latin American Classical Composers: A Biographical Dictionary, 87.

144 Tello, La música en México: Panorama del siglo XX, 616-617.

${ }^{145}$ Ficher, Furman Schleifer, and Furman, Latin American Classical Composers: A Biographical Dictionary, 404.
} 
Daniel, a young Jew that leads a group of Christians. Plancio, the proconsul of Judea arrests

Daniel and accuses him of crimes. Elena converts to Christianity and sets out to free Daniel. However, Plancio learns of this conspiracy and sentences Daniel to crucifixion. The opera did not have a successful premiere. ${ }^{146}$

Julia Alonso (b. 1889), was an Oaxacan composer, organist, pianist, and teacher. She studied in Mexico City, and taught organ, piano, and composition. She wrote the opera Tonantzin $(1915) \cdot{ }^{147}$

Arnulfo Miramontes (1882-1960), from Jalisco, studied in Mexico and Germany. ${ }^{148} \mathrm{He}$ composed Anáhuac (1918) and Cíhuatl (ca. 1920). Anáhuec premiered on 31 January 1918 in the Teatro Virginia Fábregas. This three-act opera, with a libretto by Francisco Bracho, shares the story of an indigenous man, Tizoc, who is against Spanish domination. He is part of a love triangle between Mextli, an indigenous woman, and Elvira, the daughter of Spaniard Nuño de Guzmán. It was a controversial work that some people enjoyed, while others despised it. Anáhuec was presented later that year, on 1 December 1918, at the Teatro Colón in Argentina, without the controversy that surrounded its Mexican premiere. ${ }^{149}$

Julián Carrillo (1875-1965) was a Mexican composer and teacher. He studied in Mexico and Germany, and composed several operas. He wrote Matilde (1909), which was also titled under another name, México in 1810. His opera Xiulitl (1921) has an indigenous theme. He also composed Ossiam in $1903 .{ }^{150}$

\footnotetext{
${ }^{146}$ Tello, La música en México: Panorama del siglo XX, 618-620.

${ }^{147}$ Tello, La música en México: Panorama del siglo XX, 621; Ficher, Furman Schleifer, and Furman, Latin American Classical Composers: A Biographical Dictionary, 34.

${ }^{148}$ Ficher, Furman Schleifer, and Furman, Latin American Classical Composers: A Biographical Dictionary, 278.

${ }^{149}$ Tello, La música en México: Panorama del siglo XX, 621.

${ }^{150}$ Tello, La música en México: Panorama del siglo XX, 621; Romero, La ópera en Yucatan, 58; Ficher, Furman Schleifer, and Furman, Latin American Classical Composers: A Biographical Dictionary, 96.
} 
José F. Vásquez (1895-1961), was born in the state of Jalisco, and composed several operas: Los mineros (1916), Monna Vanna (1917), Citlali (1922), El mandarín (1923), El rajah (1926), El último sueño (1928), and Vasco núñez de Balboa (1960-1961). ${ }^{151}$ Los mineros is an opera in three acts, composed to a libretto in Italian by Andrés Molina Enríquez. The plot develops in Mineral del Oro, Zacatecas, and in Mexico City during the Revolution. Los mineros was never produced. Monna Vanna is also in three acts, and written to a work of the same name by Maurice Maeterlinck. Unfortunately, the opera's musical score has been lost. ${ }^{152}$

Citlali was written in one act, to a libretto by Manuel M. Bermejo, and premiered on 19 December 1922 in the Teatro Esperanza Iris. The opera is set on the island of Xico, in Lake Chalco, during the time of the arrival of the Spanish in the New World. The warrior Chichiltzin heads the fight to defend the island, but he knows that his love will be sacrificed for the Aztec king Xicoténcatl to please the god Huitzilopochtli. Facing the problem of whether to fight for his town or save Yoloxóchitl, he is convinced by Citlali to go ahead and lead the fight and she will save Yoloxóchitl. Citlali is the daughter of Xicoténcatl and secretly loves Chichiltzin. Citlali changes places with Yoloxóchitl and is sacrificed. Cualica, Citlali's slave girl, is deeply disturbed by the Citlali's death. She poisons herself, completing the sacrifice to the gods. Citlali won a competition for Mexican opera in 1922 and was well-received by the public. ${ }^{153}$

Vásquez's opera El mandarín was written to a Spanish libretto by Manuel M. Bermejo. It was presented in the Teatro Ambeu in 1927. The one-act opera is set in China around 1911, and tells the story of Tchan-I, a blind man that lives happily with his wife and son. However, he recovers his sight and learns of his wife's unfaithfulness and the wicked behavior of his son.

\footnotetext{
151 Tello, La música en México: Panorama del siglo XX, 621, 644; Ficher, Furman Schleifer, and Furman, Latin American Classical Composers: A Biographical Dictionary, 425-426.

152 Tello, La música en México: Panorama del siglo XX, 625.

${ }^{153}$ Ibid., 623-624.
} 
After obtaining this knowledge, he damages his eyes so that he can live once again without sight. El rajah by Vásquez opened in the Teatro Arbeu on 14 June 1931. This one-act opera follows the story of the dilemma that the rajah faces when he witnesses Natalí, the court prince, pursue Mahina. Mahina is Mantamí's faithful wife, and also has captured the rajah's attention.

However, in the end, she is sacrificed. The musical nature of both El mandarin and El rajah was described by Alba Herrera y Ogazón, a Mexican musician and musicologist, as "Wagnerian in form but in musical affiliation and creation, completely eclectic." 154

El último sueño by Vásquez is a one-act opera, with a libretto in Spanish by Manuel M. Bermejo. The opera shares Enrique's story. He was recently widowed and is comforted by his friends Julieta and Javier. Enrique falls asleep and dreams of his dead wife. The opera ends when his friends find him dead in his wife's grave. ${ }^{155}$ Vásquez became the Mexican composer with the highest number of composed operas during the first part of the twentieth century. In addition to composition of these operas, they were produced. ${ }^{156}$

Arturo Cosgaya Ceballos (1869-1937) was a Yucatan composer, born in Mérida. He composed Xunáan Tunich (Mujer de piedra) (1919), the first opera written on a Mayan theme. ${ }^{157}$

Alejandro Juevas composed the opera Morgana (1920). This two-act opera has a libretto written by the composer himself, and a plot based on an ancient legend. Beppo, a fisherman, is tempted by a siren's singing, Morgana. However, Beppo is in love with Nina, who is awaiting his return. Beppo drowns, and upon discovering his body on the beach, Nina goes crazy, throws herself off an edge, and dies. The opera premiered at the Teatro Esperanza Iris on 17 July 1920.

\footnotetext{
154 Ibid., 625-626.

155 Ibid., 633.

156 Ibid., 626.

${ }^{157}$ Romero, La ópera en Yucatan, 72; Tello, La música en México: Panorama del siglo XX, 260.
} 
It was not well attended and a critic observed "the indifference and apathy of operagoers, that only admired and encouraged a work if it was foreign." 158

Yucatan composer Fernando del Castillo wrote the operas Cíhuatl (1923) and La mestiza (1925). ${ }^{159}$ Cíhuatl was presented in the theater at the National Museum, on 19 March 1923, three months after it had been entered in a competition for Mexican opera. This one-act opera's libretto was written by Catalina d'Erzell. It was based on a pre-Hispanic legend in which the daughters of the gods of death, Miquiztli, Cíhuatl, and Yólotl, all love the same man, Cuauhtli. Cuauhtli loves Cíhuatl. Cíhuatl's father curses her, and turns her into a serpent that wanders the earth. Cuauhtli desperately searches for her, finds her, and kisses her. She poisons him and he dies. The performance was poorly attended, but plans were still made to program the opera in the next season at the Teatro Esperanza Iris. ${ }^{160}$

La mestiza by Fernando del Castillo was performed in the Teatro Regis on 26 December 1925. The composer wrote his own libretto for this two-act opera, with a story that unfolds during Colonial times, in the Yucatán. The plot follows both the foundation of the city of Mérida by Francisco de Montejo, and the love affair between the mestiza Inés and don Gálvez, who is in charge of the military headquarters in the Yucatán. Del Castillo composed the opera using a mixture of styles from traditional Mayan music and tradition European music. ${ }^{161}$

Several Mexican composers wrote operas based on indigenous themes, but for many of them, there is little information about either the composer or the compositions. Carlos Samaniego composed an opera based on a national theme, Nezahualcóyotl (1923). Gustavo Río Escalante, a Yucatan composer, composed Kinchi (1924) and Xtabai (1924). Cornelio Cárdenas,

\footnotetext{
${ }^{158}$ Tello, La música en México: Panorama del siglo XX, 621-623.

${ }^{159}$ Ibid., 621.

${ }^{160}$ Ibid., 624.

${ }^{161}$ Ibid., 625.
} 
from Yucatan, composed Chichén Itzá (1924) and Ya yaax can (1928). Alberto Amaya composed Querétaro (ca. 1930) to a libretto by Heriberto Frías. Efraín Pérez Cámara composed the opera Tzentzontli (1939). ${ }^{162}$

Miguel Bernal Jiménez (1910-1956) was a Mexican composer and organist. He was born in the state of Michoacán and studied in Mexico and Italy. He wrote Tata Vasco, one of the two most performed Mexican operas of the twentieth century. It opened in the Teatro Arbeu in 1941, with a Spanish libretto that was written in five acts by Manuel Muñoz. It was composed to celebrate the fourth centennial of the arrival of the first bishop of Michoacán, Vasco de Quiroga. The plot revolves around Quiroga's evangelization of the indigenous people, and concludes with a fandango and Quiroga studying diagrams for the construction of a cathedral. Bernal Jiménez could not get approval to premier the work in the Palacio de Bellas Artes, leaving it to open in the Church of San Francisco in Pátzcuaro, Michoacán, and later to be presented in the Teatro Arbeu. The public did not favor its religious theme, and it led to criticism. Musically, there are several nationalist techniques applied to the opera including the use of indigenous melodies and motives. ${ }^{163}$

José Pablo Moncayo García (1912-1958) was a composer, pianist, percussionist, and conductor, born in Guadalajara. He composed an opera in one act, La mulata de Córdoba (1948), one of the two most performed Mexican operas of the twentieth century. The libretto was written in Spanish by Xavier Villaurrutia and Agustín Lazo. The opera is set at the end of the Colonial Era in Córdoba and Mexico City, and it follows the legend of the mulata Soledad. She has omnipresent powers and can make young men that fall in love with her go crazy. Soledad is

\footnotetext{
162 Ibid., 621, 625, 644.

${ }^{163}$ Tello, La música en México: Panorama del siglo XX, 628; Ficher, Furman Schleifer, and Furman, Latin American Classical Composers: A Biographical Dictionary, 66-67.
} 
accused of witchcraft, but a man in love with her disguises himself as a friar and helps her to escape on a vessel filled with llamas. La mulata de Córdoba was highly successful, and it was continually revived for performances at the Teatro de Bellas Artes. ${ }^{164}$

Roberto Téllez Oropeza (b. 1909) was born in the state of Puebla. He composed several operas: Nezahualcóyotl (1949), La gracia (1975), Ifigenia cruel (1976), and Acapulco (1978). ${ }^{165}$

Eduardo Hernández Moncado (b. 1899) was born in Xalapa in the state of Veracruz. He studied in Mexico City and composed the one-act opera Elena. The libretto was written in Spanish by Francisco Zendejas, and was based on a popular Mexican corrido. While Benito is in jail, his wife has dinner with Bernard, a French soldier. They have a second date, but then Elena runs into her husband, Benito, who kills her. ${ }^{166}$

Gerhart Muench (1907-1988) was born in Germany, but settled in Mexico. He composed one opera, Tumulus Veneris (1950). ${ }^{167}$

Carlos Antonio de Pádua Chávez y Rámirez (1899-1978) was a composer and conductor. He composed one opera, The Visitors. The composition was commissioned by Lincoln Kirstein, president of the New York Ballet Society. Chávez began working on the opera in 1953 in collaboration with the America poet Chester Kallman. Chávez composed the three-act opera, The Visitors, to an English libretto. Various versions of this same opera were produced, using different titles with each version: Pánfilo y Lauretta (1957); El amor propiciado (1959) was performed in Spanish; and The Visitors, in 1968, was part of the cultural program for the

\footnotetext{
164 Tello, La música en México: Panorama del siglo XX, 628-631; Ficher, Furman Schleifer, and Furman, Latin American Classical Composers: A Biographical Dictionary, 280.

${ }^{165}$ Ficher, Furman Schleifer, and Furman, Latin American Classical Composers: A Biographical Dictionary, 404; Tello, La música en México: Panorama del siglo XX, 644-645.

166 Tello, La música en México: Panorama del siglo XX, 629-630; Ficher, Furman Schleifer, and Furman, Latin American Classical Composers: A Biographical Dictionary, 206.

167 Tello, La música en México: Panorama del siglo XX, 644; Ficher, Furman Schleifer, and Furman, Latin American Classical Composers: A Biographical Dictionary, 286.
} 
Olympics in Mexico. The last version was revised one final time in 1999. The plot takes place in a villa near Florence during the fourteenth century, and tells the story of four Italian aristocrats staying there. They voluntarily isolate themselves in order to avoid the plague. ${ }^{168}$

Salvador Moreno Manzano (1916-1999) was born in Orizaba, in the state of Veracruz. He studied in Mexico and Spain, and composed one opera, Severino, that was presented on 28 June 1961. It is a one-act opera, with a libretto in Spanish by Emilio Carballido. ${ }^{169}$

Carlos Jiménez Mabarak (1916-1994) was a Mexican composer, born in Tacuba. He studied in Guatemala, Chile, Belgium, France, and Mexico. He wrote a dodecaphonic opera, Misa de seis, which was performed on 21 June 1962. He composed another opera, La Güera Rodríguez, which was presented in September 1982 in the Palacio de Bellas Artes, with a libretto in Spanish by Julio Alejandro. The story follows the life of María Ignacia Rodríguez de Velasco, who is known for her beauty and for her participation in the fight for Mexican independence. ${ }^{170}$

Luis Sandi Meneses (1905-1996) was a composer and conductor that was born in Mexico City, and composed multiple operas. Carlota is a one-act opera with a libretto in Spanish written by Francisco Zendejas. The plot reveals Empress Carlota's life in Mexico. The opera was not popular with the public. ${ }^{171}$ Sandi also composed the opera La señora en su balcón, which was presented on 2 June 1963. This one-act opera was based on a work by Elena Garro. It shares the story of Clara, a fifty-year old woman that converses with herself at different points in her life, while in search of her own identity. ${ }^{172}$

\footnotetext{
168 Tello, La música en México: Panorama del siglo XX, 633-634; Ficher, Furman Schleifer, and Furman, Latin American Classical Composers: A Biographical Dictionary, 111.

169 Tello, La música en México: Panorama del siglo XX, 632-633; Ficher, Furman Schleifer, and Furman, Latin American Classical Composers: A Biographical Dictionary, 285.

${ }^{170}$ Tello, La música en México: Panorama del siglo XX, 632, 635; Ficher, Furman Schleifer, and Furman, Latin American Classical Composers: A Biographical Dictionary, 218.

${ }^{171}$ Tello, La música en México: Panorama del siglo XX, 629, 630.

172 Tello, La música en México: Panorama del siglo XX, 632-633; Ficher, Furman Schleifer, and Furman, Latin American Classical Composers: A Biographical Dictionary, 368-369.
} 
Lan Adomián (1905-1979) was a Mexican composer that was born in Russia. From Russia, he moved to the United States to study music, then moved to Mexico and became a Mexican citizen. Adomián composed one opera, La mascherata (1972). ${ }^{173}$

Daniel Catán (b. 1949) was born in Mexico City, and studied in England and the United States. He composed a chamber opera Encuentro en el ocaso, with a libretto by Carlos Montemayor, that premiered in the Teatro de la Ciudad in 1979. Catán's second opera, La hija de Rapaccini (1989), was presented on 25 April 1991 in the Teatro de la Ciudad. It is an opera in two acts, with a libretto in Spanish that was based on Octavio Paz's theater work of the same name. ${ }^{174}$ Florencia en el Amazonas (1994) opened in the Palacio de Bellas Artes in May 1999. It is a two-act opera, written to a libretto in Spanish by Marcela Fuentes-Berain. The work was inspired by stories and characters from the Colombian writer Gabriel García Márquez. ${ }^{175}$

Alicia Urreta Arroyo (1935-1987) was a Mexican composer, pianist, and teacher from Veracruz that studied in Mexico City and Paris. Urreta composed Romance de doña Balada (1973), a chamber opera based on the story of Honoré de Balzac that was presented in El Ágora in 1974. She also composed El espejo encantado in $1985 .{ }^{176}$

Mario Stern (b. 1936) was born in Mexico City, and studied in Germany and France. He was a professor at the Escuela Nacional de Música of UNAM (National Autonomous University of Mexico) in Mexico City, and composed several operas: Jaque (1978), Big Klaus and Little Klaus (1980), and Pinocchio (1983). ${ }^{177}$

\footnotetext{
${ }^{173}$ Tello, La música en México: Panorama del siglo XX, 644; Ficher, Furman Schleifer, and Furman, Latin American Classical Composers: A Biographical Dictionary, 21-22.

174 Tello, La música en México: Panorama del siglo XX, 639-640.

175 Ibid., 640.

176 Tello, La música en México: Panorama del siglo XX, 635, 645; Ficher, Furman Schleifer, and Furman, Latin American Classical Composers: A Biographical Dictionary, 416.

177 Tello, La música en México: Panorama del siglo XX, 644; Ficher, Furman Schleifer, and Furman, Latin American Classical Composers: A Biographical Dictionary, 397.
} 
Miguel Alcázar (b. 1942) was a Mexican guitarist and composer that studied in Mexico City and in the United States. He wrote La mujer y su sombra (1978). This one-act opera was performed at the Palacio de Bellas Artes in April 1981. ${ }^{178}$

Federico Ibarra Groth (b. 1946) was the most prolific Mexican opera composer of his generation. He was also a pianist, and studied in Mexico, France, and Spain. His opera Leoncio y Lena (1980) premiered at the Teatro Juan Ruiz de Alarcón del Centro Cultural Universitario (CCU) in 1981. Orestes parte (1981) was presented in a concert version in the Sala Nezahualcóyotl in 1984 and in the Palacio de Bellas Artes in July 1987. Madre Juana (1986) was performed in the Teatro Juan Ruiz de Alarcón del CCU in December 1993. El pequeño principe (1988) was presented in Los Angeles in 1988 and in Mexico in September 1999. Alicia (1989) was performed in July 1995 and December 2001 in the Palacio de Bellas Artes, and Despertar al sueño (1994) opened 31 October 1994 in the Centro Cultural San Ángel. ${ }^{179}$

Leoncio y Lena was composed to a libretto in Spanish by José Ramón Enríquez, based on a text by Georg Büchner. The plot follows the story of Prince Leoncio of Popó and Princess Lena of Pipí, who are forced to marry for convenience, without even meeting each other. Each of them flee from their respective thrones. However, they accidentally meet, fall in love, and marry without knowing the true identity of the other. The prince and princess decide to convert their kingdom into an ideal utopia. Ibarra's next opera, Orestes parte, is a two-act opera, with a libretto by José Ramón Enríquez that is loosely based on the tragedy Los coéforas by Esquilo. In the story, Orestes assassinates his stepfather, Egisto, and his mother, Clitemnastra. ${ }^{180}$

\footnotetext{
178 Tello, La música en México: Panorama del siglo XX, 635; Ficher, Furman Schleifer, and Furman, Latin American Classical Composers: A Biographical Dictionary, 28.

${ }_{179}$ Tello, La música en México: Panorama del siglo XX, 637-638; Ficher, Furman Schleifer, and Furman, Latin American Classical Composers: A Biographical Dictionary, 211.

${ }^{180}$ Tello, La música en México: Panorama del siglo XX, 636-637.
} 
Madre Juana was written in two acts, with a libretto by José Ramón Enríquez, that was based on Los demonios de Loudon by Aldous Huxley. The story surrounds the trial of a priest, Grandier, accused of witchcraft against Mother Superior Juana de los Ángeles and the nuns in the convent in Loudun in the seventeenth century. El pequeño principe is a chamber opera in one act, with a libretto by Luis de Tavira, adapted from the story Le petit prince by Antoine de SaintExupéry. The opera is set in a city where the small prince is a type of angel that crosses through different dramatic situations. Alicia is an opera in two acts, with a libretto by José Ramón Enríquez, based on Alice in Wonderland and Alice Through the Looking Glass, both by Lewis Carroll. Despertar al sueño is a chamber opera in one act, with a libretto by David Olguín. ${ }^{181}$ José Antonio Guzmán (b. 1946) was a composer and harpsichord performer. In 1984, he composed El monje, which was also known as Ambrioso o la fábula del mal amor. This three-act opera was composed to a libretto in Spanish by José Antonio Guzmán. It was based on the novel The Monk by Matthew Lewis, although the setting was moved to Mexico in 1697. El monje opened in the Sala Miguel Covarrubias del CCU and in the Palacio de Bellas Artes. ${ }^{182}$

Rafael Olvera (b. 1959) was born in Huachinango, in the state of Puebla, and he studied both in Mexico City and the United States. Olvera composed the opera El cuarto Rey Mago (1985). ${ }^{183}$

Carlos Pazos (b. 1953) was from Oaxaca, and studied in Russia and Spain. He composed Popol Vuh in $1985 .{ }^{184}$

\footnotetext{
${ }^{181}$ Ibid., 637-638.

182 Tello, La música en México: Panorama del siglo XX, 639; Ficher, Furman Schleifer, and Furman, Latin American Classical Composers: A Biographical Dictionary, 199.

${ }_{183}$ Tello, La música en México: Panorama del siglo XX, 645; Ficher, Furman Schleifer, and Furman, Latin American Classical Composers: A Biographical Dictionary, 303.

${ }^{184}$ Tello, La música en México: Panorama del siglo XX, 645; Ficher, Furman Schleifer, and Furman, Latin American Classical Composers: A Biographical Dictionary, 317.
} 
Manuel Enríquez Salazar (1926-1994) was born in Ocotlán in the state of Jalisco. He was a violinist and composer who studied at the Conservatory of Guadalajara and at the Julliard School of Music in New York. He composed La encrucijada in 1990. ${ }^{185}$

Mario Lavista (b. 1943) was a Mexican composer that studied in France and Germany. His opera Aura (1988) premiered in the Palacio de Bellas Artes on 13 Abril 1989. The Spanish libretto was written by Juan Tovar and based on a work by Carlos Fuentes. ${ }^{186}$

Marcela Rodríguez (b. 1951) was a Mexican composer and guitarist, born in Mexico City. She studied in Mexico, the United States, and Germany. She wrote La sunamita (1990), which was presented on 1 August 1991 at the Teatro de la Ciudad. The two-act opera, with a libretto in Spanish by Carlos Pereda, was based on the story of the same name by Inés Arredondo. ${ }^{187}$

Hilda Paredes (b. 1957) was a Mexican composer that was born in Puebla, and studied in Mexico, England, and Italy. Her chamber opera, La séptima semilla (1991), opened at the Teatro Juan Ruiz de Alarcón del CCU on 28 June 1993. It was written in two acts, with a libretto in English by Karen Whiteson. The action takes place in a London basement, and is set during the time period when the opera was written (1990s). It combines the Greek myth Persephone with characters and situations from Alice in Wonderland by Lewis Carroll. ${ }^{188}$

Several other works were presented in the last decade of the twentieth century, with little information provided about the composer and the composition. Some of these works include the

\footnotetext{
${ }^{185}$ Tello, La música en México: Panorama del siglo XX, 645; Ficher, Furman Schleifer, and Furman, Latin American Classical Composers: A Biographical Dictionary, 131.

${ }^{186}$ Tello, La música en México: Panorama del siglo XX, 638; Ficher, Furman Schleifer, and Furman, Latin American Classical Composers: A Biographical Dictionary, 235.

${ }^{187}$ Tello, La música en México: Panorama del siglo XX, 640; Ficher, Furman Schleifer, and Furman, Latin American Classical Composers: A Biographical Dictionary, 350.

${ }^{188}$ Tello, La música en México: Panorama del siglo XX, 640; Ficher, Furman Schleifer, and Furman, Latin American Classical Composers: A Biographical Dictionary, 313.
} 
following operas and their composers. Víctor Rasgado (b. 1959) studied in Mexico City and Italy, and composed the opera Anacleto Morones in $1991 .^{189}$ Leandro Espinosa (b. 1955) was a Mexican composer and cellist that composed the opera Ifigenia cruel in $1992 .{ }^{190}$ Gerardo Tamez (b. 1948) was a Mexican composer that was born in Chicago. In 1992, he composed the opera Dos mundos. ${ }^{191}$ Alberto Alvarado López (b. 1956) was a Mexican clarinetist and composer. He studied in London, the United States, and Mexico City, and composed the opera Mambo (1993). ${ }^{192}$ Fernando Cataño (b. 1928) was born in Mexico City. He played contrabass and composed several works, including an opera, Llamadas de Oriente (1993). ${ }^{193}$ Julio Estrada (b. 1943) was a Mexican musicologist, teacher, and composer that studied in both Mexico and Germany. He wrote Pedro Páramo (1991), which premiered as Doloritas in 1993. It was revised and presented in the current version in $2000 .{ }^{194}$ Sergio Berlioz (b. 1963) was a Mexican composer and musicologist that composed the opera En tiempo del ave in $1995 .{ }^{195}$ Luis Jaime Cortez (b. 1962) composed the two-act opera La tentación de San Antonio (1997), which was performed in May 1998 at the Teatro de las Artes. The composer wrote the libretto in Spanish, and based it on a work by Gustav Flaubert. ${ }^{196}$

\footnotetext{
${ }^{189}$ Tello, La música en México: Panorama del siglo XX, 645; Ficher, Furman Schleifer, and Furman, Latin American Classical Composers: A Biographical Dictionary, 340.

${ }^{190}$ Tello, La música en México: Panorama del siglo XX, 645; Ficher, Furman Schleifer, and Furman, Latin American Classical Composers: A Biographical Dictionary, 145.

${ }^{191}$ Tello, La música en México: Panorama del siglo XX, 645; Ficher, Furman Schleifer, and Furman, Latin American Classical Composers: A Biographical Dictionary, 400.

192 Tello, La música en México: Panorama del siglo XX, 645; Ficher, Furman Schleifer, and Furman, Latin American Classical Composers: A Biographical Dictionary, 37.

${ }^{193}$ Tello, La música en México: Panorama del siglo XX, 645; Ficher, Furman Schleifer, and Furman, Latin American Classical Composers: A Biographical Dictionary, 106.

194 Tello, La música en México: Panorama del siglo XX, 640-641; Ficher, Furman Schleifer, and Furman, Latin American Classical Composers: A Biographical Dictionary, 146.

195 Tello, La música en México: Panorama del siglo XX, 645; Ficher, Furman Schleifer, and Furman, Latin American Classical Composers: A Biographical Dictionary, 66.

${ }^{196}$ Tello, La música en México: Panorama del siglo XX, 640.
} 


\section{Chapter 4: South America}

The South American countries discussed in this research are the Spanish-speaking nations of Argentina, Chile, Colombia, Paraguay, Peru, Uruguay, and Venezuela. Information was not located about opera composers or the development of a national opera in Bolivia or Ecuador. While Brazil is an important nation of South America, and has a rich operatic tradition, as a Portuguese-speaking country, it is not included in this research.

The development of a national opera in South America is largely centered in Lima, Peru and Buenos Aires, Argentina. These two cities were the birthplaces of important opera compositions, and still today are home to famous opera houses that produce numerous operas each year. From these cities, opera spread through the rest of South America, and formed under the same influences as Mexico, with Spanish and Italian operas having the greatest impact on developing opera. Early opera was created either for the Church or the court, and mission operas were popular in various regions of South America.

The Jesuit missions of South America developed an operatic tradition, because they believed that the correlation of music and drama in opera could be used to spread religion and educate the indigenous people. However, within the city of Lima, most operas were based on secular themes. These early operas in Lima drew inspiration from Spain, and from Italian and French operatic traditions. ${ }^{197}$

Lima was the "administrative, military, and religious epicenter" of Spain in the New World. The Viceroy was established in Lima, the city was a center for trade, and for a period of time, it was extremely wealthy. As Spain underwent financial challenges due to the War of

\footnotetext{
${ }^{197}$ Gasta, Transatlantic Arias: Early Opera in Spain and the New World, 23.
} 
Succession (1701-1714), Lima's development was affected. The arts were generally funded by the Crown and therefor suffered with Spain's financial difficulties. ${ }^{198}$

Argentine opera began to be produced on a large scale late in the nineteenth century, mostly in Buenos Aires. The original Teatro Colón opened in 1857, the Teatro de la Opera in 1872, the Teatro Politeama in 1879 , and the Teatro Nacional in 1882 . After the theaters were built, both major European and local companies occupied them. The new Teatro Colón of Buenos Aires was established in 1908, and it provided motivation for the continued presence of opera in Argentina. The creation of these theaters helped to establish Buenos Aires as a major opera center of the world. ${ }^{199}$

Argentine composers used the idea of Italian verismo to structure their nationalist trends. Several composers wrote operas that were derived from Argentine and Latin American folk legends, and based on either true folk or popular musical themes, including these composers who will be discussed later: Pascual de Rogatis (b. 1881), Enrique Mario Casella (1891-1948), Arnaldo D’Espósito (1907-1945), Constantino Gaito (1878-1945), and Felipe Boero (1884$1958) .^{200}$

\footnotetext{
${ }^{198}$ Ibid., 83, 96.

${ }^{199}$ Béhague, Music in Latin America: An Introduction, 106-107.

${ }^{200}$ Ibid., 212.
} 


\section{Argentina: Operas and Composers}

Eduardo Torrens Boqué was a native of Spain that moved to Argentina after visiting several American countries. He composed two operas. Gualterio premiered in the Teatro de la Ópera on 4 August 1883, and Il segreto premiered in the Teatro Politeama Argentino on 11 October $1900 .^{201}$

Francisco A. Hargreaves (1849-1900), a distinguished pianist and composer, was the grandson of an American that settled in Argentina. He was one of the first Argentine composers to derive material from folk-music sources and "is often considered in Argentina as a pioneer of national music." ${ }^{202}$ His opera, La gatta bianca, was written while he was in Europe and premiered in Vilà, a small city near Florence, in 1875. The libretto was derived from a French story. The opera was first performed in Buenos Aires, 11 January 1877, in the Teatro de las Victorias. $^{203}$

Hargreaves won a prize for his second opera, El vampiro (1876). ${ }^{204}$ The libretto for this opera was based on an adaptation of the book, Mil y un fantasmas, by Alejandro Dumas. ${ }^{205} \mathrm{He}$ also composed the opera Los estudiantes de Bolonia, with a libretto by Angel Menchaca. The libretto was inspired by a chapter of the book Los mil y un fantasmas by Alejandro Dumas. The opera premiered in the Teatro de la Victoria, 24 April 1897, during a tour by a Spanish zarzuela company, who presented the opera in Spanish. ${ }^{206}$

\footnotetext{
${ }^{201}$ Enzo Valenti Ferro, Historia de la ópera argentina (Buenos Aires, Argentina, Ediciones de Arte Gaglianone, 1997), 14, 17, 23; Ficher, Furman Schleifer, and Furman, Latin American Classical Composers: A Biographical Dictionary, 410.

${ }^{202}$ Béhague, Music in Latin America: An Introduction, 107; Ficher, Furman Schleifer, and Furman, Latin American Classical Composers: A Biographical Dictionary, 202; Valenti Ferro, Historia de la ópera argentina, 15.

${ }^{203}$ Valenti Ferro, Historia de la ópera argentina, 15, 17, 85.

${ }^{204}$ Béhague, Music in Latin America: An Introduction, 107.

${ }^{205}$ Valenti Ferro, Historia de la ópera argentina, 17.

${ }^{206}$ Ibid., 17.
} 
Eduardo García Lalanne (1863-1937) was born in Buenos Aires, and later resided in Italy where he studied music at the Conservatory and began his conducting career. He was an orchestra director and composed several zarzuelas. His three-act opera, Esmeralda, was based on the book Nôtre Dame de París by Víctor Hugo. Esmeralda opened in the Teatro Onrubia on 7 June $1890 .^{207}$

Pablo María Berutti (1863-1914), brother of Arturo Berutti, composed the opera Cochabamba (1890) in three acts. The Teatro de la Ópera announced the premiere of Cochabamba, but it never was produced. ${ }^{208}$

Corradino d'Agnillo (1868-1948), in collaboration with orchestra director Enea Verardini, composed El León de Venecia. It was presented in the Teatro Politeama Argentino on 8 October $1892 . .^{209}$

Juan Grazioso Panizza (1851-1898) was a cellist and composer. His opera Clara was based on the book Le dernier des Abencerrages by François de Chateaubriand. It premiered in Milan's Teatro Mazoni in 1893 and in Argentina in 1897. He composed another opera, Cecilia, that premiered the 14 September $1897 . .^{210}$

Arturo Berutti (1858-1938) composed the opera Taras Bulba, which was performed on 20 July 1895 in the Teatro de la Ópera. Taras Bulba and two other operas composed by Berutti were performed in Italy: Vendetta and Evangelina. Evangelina opened in Buenos Aires in the Teatro San Martín on 29 October 1895, and had premiered in Milan two years prior. Berutti’s opera Pampa premiered on 27 July 1897, in the Teatro de la Ópera. The libretto was written in

\footnotetext{
${ }^{207}$ Valenti Ferro, Historia de la ópera argentina, 20; Ficher, Furman Schleifer, and Furman, Latin American Classical Composers: A Biographical Dictionary, 312.

${ }^{208}$ Valenti Ferro, Historia de la ópera argentina, 25.

${ }^{209}$ Ibid., 17.

${ }^{210}$ Ibid., 19.
} 
Italian by Guido Borra, with inspiration from the gaucho drama Juan Moreira by Eduardo Gutiérrez. $^{211}$

Another opera by Berutti is Yupanki. It was the last operatic premiere of the century, occurring the 25 July 1889 in the Teatro de la Ópera. The opera was based on an Incan legend that was extracted from the book Las razas arianas by Vicente Fidel López. Enrique Rodríguez Larreta wrote the libretto in Spanish, and it was later translated to Italian by José Tornassi. ${ }^{212}$ In his study of Arturo Berutti, musicologist Juan María Veniard noted that this opera was not translated to Italian out of tradition or common standards, but rather because "to create an opera, even one based on an Incan theme, would be more authentic sung in Italian than in Spanish."213 However, Enzo Valenti Ferro, the author of Historia de la ópera argentina, disagreed with this opinion, stating that the codes of that time period made it impossible for a cast of visiting Italian singers to sing in Spanish. ${ }^{214}$

Khrysé by Berutti was a four-act opera based on Afrodita by Pierre Louys. Berutti wrote the libretto himself, in Spanish, and it was later translated to Italian by Giuseppe Paolo Pacchierotti. Khrysé premiered in the Teatro Politeama Argentino on 29 June 1902. ${ }^{215}$ Horrida Nox, another opera with music and text by Berutti, was produced at the Teatro Politeama Argentino on 7 July $1908 .{ }^{216}$ His historic opera Los heroes was composed to a libretto by Herminio Campana, and opened at the Teatro Colón on 23 August 1919. ${ }^{217}$ He composed

\footnotetext{
${ }^{211}$ Ibid., 17-18, 20.

${ }^{212}$ Ibid., 22.

${ }^{213}$ Ibid., 22.

${ }^{214}$ Ibid., 22.

${ }^{215}$ Ibid., 24.

${ }^{216}$ Ibid., 25.

${ }^{217}$ Ibid., 30.
} 
another history-based opera, Facundo. This opera was three acts, and focused on the figure of Juan Facundo Quiroga and the civil wars. ${ }^{218}$

Héctor Panizza (1875-1967) composed Il Fidanzato del mare to a libretto by Romeo Carugati, and it was presented at the Teatro de la Ópera on 13 August 1897. The opera was originally written in the form of a cantata, and later modified for theater. It is largely a duet between soprano and tenor, with a town of fishermen that form the chorus. ${ }^{219}$ His next opera, Medioevo Latino, opened in the Teatro Politeama de Génova on 17 November 1900, and it was later presented by the Teatro de la Ópera on 21 July 1901. The libretto was written by Luigi Illica. The opera was a trilogy: "Las Cruzadas," "Las Cortes de amor," and "En Cádiz."220

Panizza's opera Aurora opened during the inaugural season of the new Teatro Colón on 5 September 1908. Héctor Quesada and Luigi Illica wrote the libretto, based on events from the fight for Argentine independence. The opera was originally sung in Italian, and in 1945, it was replaced with a Spanish version. ${ }^{221}$ Bizancio was presented on 25 July 1939 in the Teatro Colón. Gustavo Macchi wrote the libretto for this opera, which was set during the decline of the Roman Empire. 222

Ferruccio Cattelani (1867-1932), Italian by birth, moved to Buenos Aires in 1897. He was a violinist and composer. His opera Atahualpa premiered in the Teatro San Martín on 10 March $1900 .^{223}$

\footnotetext{
218 Ibid., 30-31.

219 Ibid., 20.

${ }^{220}$ Ibid., 24.

221 Ibid., 25.

222 Ibid., 44-45.

${ }^{223}$ Ibid., 22-23.
} 
Ricardo Bonicioli was born in Italy, and was a well-known orchestra director and composer in Buenos Aires. He composed the opera Juan de Garay, a melodramatic sketch in two acts. $^{224}$

Constantino Gaito (1878-1945) composed eight operas, six of which were produced. Shafras premiered 29 October 1907 in the Teatro Politeama Argentino. It was composed in one act, with a libretto by Ferruccio Scubla. ${ }^{225}$ Petronio opened at the Teatro Colón on 2 September 1919, with a libretto by Humberto Romanelli. ${ }^{226}$ Flor de nieve, with a libretto by Giuseppe Colelli, premiered 3 August 1922. The one-act opera takes place in the Abruzzo region of Italy. ${ }^{227}$ Gaito's next opera, Ollantay, opened at the Teatro de Colón on 23 June 1926. Víctor Mercante wrote the libretto for the opera. ${ }^{228}$ Lázaro was another collaboration between Gaito and Mercante. It premiered 19 November 1929 at the Teatro Colón. La sangre de las guitarras was presented 17 August 1932 at the Teatro Colón, with a libretto by Vicente G. Reta and Carlos Max Viale, who based the work on a story by Héctor Pedro Blomberg. ${ }^{229}$ Juan Bautista Massa (1885-1938) was a composer and pedagogue, born in Buenos Aires. Zoraida was in two acts with a libretto by Ivo Cei. It opened 15 May 1909 in the Teatro Coliseo Argentino, but was not well-received. L'Evaso was presented at the Teatro de la Ópera de Rosario on 22 June 1922, at the intermission of a symphony concert directed by Bruno Bandini. ${ }^{230}$ La Magdalena premiered at the Teatro Colón on 9 November 1929, with a libretto by Ernesto Trucchi. ${ }^{231}$

\footnotetext{
${ }^{224}$ Ibid., 23.

${ }^{225}$ Ibid., $24-25$.

${ }^{226}$ Ibid., 30-31.

${ }^{227}$ Ibid., 34.

${ }^{228}$ Ibid., 37.

${ }^{229}$ Ibid., 40.

${ }^{230}$ Ibid., 26, 35.

${ }^{231}$ Ibid., 40.
} 
César A. Stiattesi (1881-1934) was born in Nice to French parents, but relocated to Argentina as a child. He composed the opera Blanca de Beaulieu to an Italian libretto by Humberto Romanelli, based on a novel by Alejandro Dumas. The libretto was translated to Spanish by Xavier Santero. It was the first Argentine opera sung in Spanish in the Teatro Colón, and was produced 1 October 1910 in this theater. ${ }^{232}$

Carlos López Buchardo (1881-1948) was born in Buenos Aires, and he studied in both Argentina and France. He composed Sueño de alma to a libretto by Leopoldo Díaz, and it premiered 4 August 1914 in the Teatro Colón. It was his only opera, although he did compose other works for the theater. ${ }^{233}$

Alfredo Luis Schiuma (1885-1963) was born in Italy and became a naturalized Argentine. His opera Blancaflor opened at the Teatro Coliseo on 8 January 1915. Amy Robsart, with a libretto by Agenor Magno, premiered 23 April 1920 at the Teatro Coliseo. ${ }^{234}$ La sirocchia was presented at the Teatro Odeón on 23 April 1922. The libretto was written by Agenor Magno, who built the plot around a story by Boccaccio. The opera was later translated to Spanish and given a new title, Litigio de amor. With its new title, it appeared at the Teato Colón on 15 September 1932. It was also presented at the Teatro Coliseo. ${ }^{235}$ Tabaré, an opera in three acts, opened at the Teatro Colón on 6 August 1925. Jorge Servetti Reeves wrote the libretto, inspired by a poem written by Uruguayan poet Juan Zorrilla de San Martín. ${ }^{236}$ Las vírgenes del sol was composed by Schiuma to a libretto by Ataliva Herrera, a writer from Córdoba. It premiered 9

\footnotetext{
${ }^{232}$ Valenti Ferro, Historia de la ópera argentina, 26; Ficher, Furman Schleifer, and Furman, Latin American Classical Composers: A Biographical Dictionary, 397.

${ }^{233}$ Valenti Ferro, Historia de la ópera argentina, 26-27; Ficher, Furman Schleifer, and Furman, Latin American Classical Composers: A Biographical Dictionary, 244-245.

${ }^{234}$ Valenti Ferro, Historia de la ópera argentina, 27, 33.

${ }^{235}$ Ibid., 34.

${ }^{236}$ Ibid., 37.
} 
July 1939 at the Teatro Colón. The plot is set in the Incan world at a time when the Spanish conquistadors appeared. ${ }^{237}$

Eduardo García Mansilla (1870-1930) composed two operas. The first was Ivan, which was presented 20 July 1916 in Buenos Aires. Ivan was dedicated to the tsar Nicholas II, and premiered in Petersburgo (Russia) in the Teatro del Hermitage years prior to its appearance in Buenos Aires. The opera was also presented at La Scala in Milan and at the Teatro Costanzi in Rome. His second opera was La angelical Manuelita. It was a one-act opera with a libretto based on events that transpired with his great-aunt, Manuelita Rosas. It opened 5 August 1917 in the Teatro Colón. ${ }^{238}$

Pascual de Rogatis (1884-1980) composed two operas. His opera Huemac, with a libretto by Edmundo Montagne, was based on an Aztec myth. It premiered at the Teatro Colón on 22 July 1916. ${ }^{239}$ La novia del Hereje opened on 13 June 1935 at the Teatro Colón. It was written to a libretto by Tomás Allende Iragorri, that was inspired by a novel of Vicente Fidel Lódiez. ${ }^{240}$ Felipe Boero (1884-1958) composed a one-act opera, Tucumán, with a libretto by Leopoldo Díaz. It premiered in the Teatro Colón on 29 June 1918. At its premiere, the opera was sung in Spanish and included three Argentine singers. ${ }^{241}$ Ariana y Dionysos, with a libretto by Leopoldo Díaz, opened on 7 August 1920 at the Teatro Colón. ${ }^{242}$ Raquela, another collaboration with Leopoldo Díaz, opened at the Teatro Colón on 26 June 1923. The plot is set in Pampa, and Argentine singers were included in its cast. ${ }^{243}$ Boero's opera El matrero premiered in 1929, with

\footnotetext{
${ }^{237}$ Ibid., 44.

${ }^{238}$ Ibid., 28-29.

${ }^{239}$ Béhague, Music in Latin America: An Introduction, 212; Valenti Ferro, Historia de la ópera argentina, 28.

${ }^{240}$ Valenti Ferro, Historia de la ópera argentina, 42.

${ }^{241}$ Ibid., 29.

${ }^{242}$ Ibid., 33.

${ }^{243}$ Ibid., 36.
} 
a libretto by Yamandú Rodríguez. It was presented on 12 July 1929 at the Teatro Colón. ${ }^{244}$ On 8 June 1937, Siripo premiered at the Teatro Colón. The libretto was inspired by Manuel José de Lavarden's work about dramatic events from the Conquest, and was written by Luis Bayon Herrera. ${ }^{245}$ Zincali was a three-act opera based on a libretto by Arturo Capdevila. The plot surrounds gypsies in southern France. ${ }^{246}$

August Maurage (1875-1925) was a violinist, orchestra director, and composer. He was born in Belgium and lived in Buenos Aires. Maurage directed the premiere of his opera, Tupá, on 8 April 1919 at the Teatro San Martín. Eduardo Montagne wrote the libretto for this opera. ${ }^{247}$ Les noces d'or, with a libretto by Armand Crabbé, opened at the Teatro Odeón on 25 July $1924 .^{248}$

Floro M. Ugarte (1884-1975) composed and wrote the text for Saika, which opened at the Teatro Colón on 22 June 1920. ${ }^{249}$

Ilse was the first opera by composer and pedagogue Gilardo Gilardi (1889-1963). Cosme Giergi Contri wrote the two-act libretto, and set the opera in a German city. It was presented at the Teatro Colón on 13 July 1923. ${ }^{250}$ La leyenda del Urutaú opened on 25 October 1932 in the Teatro Colón. ${ }^{251}$

\footnotetext{
${ }^{244}$ Béhague, Music in Latin America: An Introduction, 212; Valenti Ferro, Historia de la ópera argentina, 39.

${ }^{245}$ Valenti Ferro, Historia de la ópera argentina, 44.

246 Ibid., 47.

247 Ibid., 29-30.

248 Ibid., 37.

${ }^{249}$ Valenti Ferro, Historia de la ópera argentina, 33; Ficher, Furman Schleifer, and Furman, Latin American Classical Composers: A Biographical Dictionary, 415.

${ }^{250}$ Valenti Ferro, Historia de la ópera argentina, 36.

251 Ibid., 41.
} 
Athos Palma (1891-1951) was an Argentine composer and pedagogue. He composed Nazdah to a libretto by Gino de San Leo. It is set in India, and based on La nodriza by Eça de Queiroz. The opera premiered at the Teatro Colón on 19 June 1924. ${ }^{252}$

Chrysantheme was a one-act opera composed by Rafael Peacan del Sar (1884-1960). The libretto was written by Giuseppe Colelli, who drew his inspiration from a novel by Pierre Loti. It was presented at the Teatro Colón on 14 June $1927 . .^{253}$

Raúl H. Espoile (1888-1958) composed an opera in four acts, Frenos, that premiered at the Teatro Colón on 19 June 1927, with a libretto by Víctor Mercante. ${ }^{254}$ La ciudad roja was presented on 17 July 1937 at the Teatro Colón, with a libretto by Carlos Schaeffer Gallo. The plot takes place during the Era of Rosas (nineteenth century). ${ }^{255}$

Arturo Luzzatti (1875-1959) was born in Italy, but later relocated to Argentina and assumed Argentine nationality. He composed Afrodita, with a libretto by Théophile Puget and Gabriel Bernard, derived from a book by Pierre Louys. ${ }^{256}$

Arturo de Angelis (1879-1916) was an Argentine composer and a native of Italy. His opera Beatrice, with a libretto by Folco Testena, premiered on 25 March 1933 at the Teatro Politeama Argentino. ${ }^{257}$

Alfredo Pinto (1891-1968) was born in Italy and relocated to Argentina. The composer and pianist wrote the opera Gualicho to a libretto by Rosario Beltrán Núñez. The libretto shares the story of a pair of lovers, their problems, and a good-luck charm. ${ }^{258}$

\footnotetext{
252 Ibid., 36.

253 Ibid., 38.

254 Ibid., 38.

255 Ibid., 44.

256 Ibid., 39.

${ }^{257}$ Valenti Ferro, Historia de la ópera argentina, 42; Ficher, Furman Schleifer, and Furman, Latin American Classical Composers: A Biographical Dictionary, 41.

258 Valenti Ferro, Historia de la ópera argentina, 45.
} 
Arnaldo d'Espósito (1907-1945) presented his opera Lin Calel in the Teatro Colón on 10 August 1941. The libretto was written by Víctor Mercante, and was based on Eduardo L. Holmberg's poem, "Las razas." 259

Juan José Castro (1895-1968) wrote two operas based on works by Federico García Lorca: La zapatera prodigiosa (1943) and Bodas de sangre (1953). ${ }^{260}$ La zapatera prodigiosa was presented in Uruguay at the Teatro de la Ossodre on 27 October 1949. This was the first of four operas by Castro and was written as a tribute to García Lorca. ${ }^{261}$ Bodas de sangre premiered 9 August 1956 in the Teatro Colón, and was also written to honor García Lorca. ${ }^{262}$ Proserpina y el extranjero opened on 3 September 1960 at the Teatro Colón, with a libretto by Omar del Carlo. The plot follows the myth of the abduction of Proserpina through daily activities in the world of someone living in Buenos Aires. ${ }^{263}$ Castro had one unfinished opera, Cosecha negra. ${ }^{264}$ María Isabel Curubeto Godoy (1898-1959) composed the opera Pablo y Virginia.

Giuseppe Adami and Renato Simone wrote the libretto, and it premiered on 2 August 1946 at the Teatro Colón. ${ }^{265}$

Juan Agustín García Estrada (1895-1961) was the composer and librettist of the opera La cuarterona (1951), with the subtitle "Cuadros de Buenos Aires en tiempo de la Colonia..." This was his only opera. ${ }^{266}$

Jacobo Ficher (1896-1978) was born in Odessa (Ukraine) and moved to Buenos Aires in 1923, where he lived for the rest of his life, and was an active part of the musical scene. He

\footnotetext{
${ }^{259}$ Ibid., 46.

${ }^{260}$ Béhague, Music in Latin America: An Introduction, 213-214.

${ }^{261}$ Valenti Ferro, Historia de la ópera argentina, 48-49.

262 Ibid., 47.

263 Ibid., 51.

264 Ibid., 61.

265 Ibid., 46.

266 Ibid., 46.
} 
composed two chamber operas, El oso (1952) and Pedido de mano (1956), both written to stories by Chejov. Pedido de mano was presented at the Teatro Presidente Alvear de Buenos Aires on 12 September $1968 . .^{267}$

El oro del Inca premiered in the Teatro Colón on 25 September 1953. Héctor Iglesias Villoud (1913-1988) wrote both the music and the libretto, which is set in the indigenous American world. ${ }^{268} \mathrm{He}$ composed another opera as well, Redención (1955). ${ }^{269}$

José María Castro (1892-1964) was an Argentine composer, conductor, and cellist. ${ }^{270} \mathrm{He}$ composed La otra voz on a libretto by Jorge de Obieta. ${ }^{271}$

Valdo Sciammarella (1924-2014) composed Marianita Limeña to a libretto by Francisco Javier. The opera was presented at the Teatro Presidente Alvear on 11 November 1957, and later at the Teatro Colón on 10 July $1962 .{ }^{272}$

Francisco de Madina (1907-1972) was an Argentine citizen that was born in Spain. Flor de Durazno opened on 29 November 1957 at the Teatro Argentino de La Plata. It was composed to a libretto by Carlos Cucullo that was based on a Hugo Wast novel. ${ }^{273}$

La pendiente was the first opera by Pompeyo Camps (1924-1997). It premiered at the Teatro de los Independientes de Buenos Aires on 2 November 1959, with a libretto written by Camps himself. ${ }^{274} \mathrm{He}$ also wrote the music and text for his second opera, La hacienda, which opened on 7 May 1987 at the Teatro Colón. ${ }^{275}$ His third opera, Maratón, premiered at the Teatro Colón on 19 December 1990. The libretto contains two acts and was written by Ricardo

\footnotetext{
${ }^{267}$ Ibid., 53.

268 Ibid., 47.

${ }^{269}$ Ficher, Furman Schleifer, and Furman, Latin American Classical Composers: A Biographical Dictionary, 212.

${ }^{270}$ Ibid., 103.

${ }^{271}$ Valenti Ferro, Historia de la ópera argentina, 47.

272 Ibid., 48.

273 Ibid., 48.

274 Ibid., 49.

275 Ibid., 57.
} 
Monti. ${ }^{276}$ La oscuridad de la razón has a libretto set in a South American province around 1930, written by Ricardo Monti. This three-act opera was commissioned by the Teatro Colón, and was presented there on 7 November $1995 .^{277}$

Alberto Ginastera (1916-1983) composed several operas that were highly successful in Buenos Aires, New York, and Washington: Don Rodrigo (1963-1964), Bomarzo (1966-1967), and Beatrix Cenci (1971). ${ }^{278}$ Don Rodrigo premiered at the Teatro Colón on 24 July 1964, with a libretto by Alejandro Casona. He hoped to combine the traditional and the contemporary in the opera by replacing the romantic language of traditional opera with an everyday language that would provide his opera with a contemporary character. However, at the same time, he wanted to maintain traditional standards of drama and music in opera. When Ginastera was asked how he wanted the opera to be sung, he replied that it should be like Otello. ${ }^{279}$

Ginastera had a gift for connecting musical and dramatic elements in his operas. In Don Rodrigo, the same dramatic progression is employed in each of the three acts, which also consists of three scenes each. Instrumental interludes separate each scene and the scenes are designed in an arch form. There is a palindromic framework to the nine scenes, "with each pair having opposite emotional meaning and with scene V the climax." ${ }^{280}$ The use of vocal techniques in the opera include "simple speech with prosodic rhythm, speech with musical rhythm and relative pitch, Sprechstimme, recitatives ranging from slow to fast delivery of syllables, and regular singing."281

\footnotetext{
276 Ibid., 59.

${ }^{277}$ Ibid., 65-66.

278 Béhague, Music in Latin America: An Introduction, 333.

${ }^{279}$ Valenti Ferro, Historia de la ópera argentina, 52.

${ }^{280}$ Béhague, Music in Latin America: An Introduction, 333.

${ }^{281}$ Ibid., 333.
} 
Ginastera employed two unique uses of spatial music in Don Rodrigo. In the first scene of Act II, eighteen horns played hunting calls from around the room. The second use of spatial music happened at the end of the opera when twenty-four bells were divided into three groups and situated around the room. The bells played in a random manner with one group sounding a chromatic scale, while the other two groups played pitches based on a twelve-tone row. The strings supported the bells by playing a chromatic chord with microtones, and the woodwinds and brass supported them by sounding a chord derived from the same series as the bells. ${ }^{282}$

Bomarzo by Ginastera was presented on 19 May 1967 in the auditorium Lisner at George Washington University in Washington D.C. The libretto was written by Manuel Mujica Láinez. ${ }^{283}$ Ginastera's final opera was Beatrix Cenci, which opened at the Teatro Colón on 2 July 1992, several years after its 1971 premiere at the Kennedy Center in Washington D.C. The opera had been commissioned by the Opera Society of Washington. The libretto was a collaboration between Scottish-born Argentine poet William Shand and writer Alberti Girri. Ginastera had one unfinished opera, Barrabás. ${ }^{284}$

Rodolfo Arizaga (1926-1985) was a composer and music critic. His opera Prometeo 45 was presented at the Teatro Argentino de La Plata on 4 September 1965. He both composed the music and wrote the libretto, with a structure that highlighted the text and situated the music in a secondary role to the drama. ${ }^{285}$

Antonio Tauriello (1931-2011) was a conductor, pianist, and composer. He conducted several orchestras, including the orchestra of the Teatro Colón of Buenos Aires, the Lyric Opera

\footnotetext{
282 Ibid., 335.

${ }^{283}$ Valenti Ferro, Historia de la ópera argentina, 53.

284 Ibid., 55, 61.

285 Ibid., 52.
} 
of Chicago, IL, the Opera Society of Washington D.C., and the New York City Opera. He wrote two operas, Escorial (1966) and Les guerres picrocholines (1971). ${ }^{286}$

Mario Perusso (b. 1936) was a composer and orchestra director. His first dramatic work was the one-act opera La voz del silencio, with a libretto by Leonidas Barrera Oro. It premiered at the Teatro Colón on 25 November 1969. His second opera, Escorial, was presented at the Teatro Colón on 19 December 1989. The libretto for this one-act opera was adapted by the composer from a theater work by the Belgian dramatist Michel de Ghelderode. Perusso also composed the opera Guayaquil, with a libretto by Agustín Pérez Pardellas. It premiered for the first time at the Teatro Colón on 8 June 1993. ${ }^{287}$

Claudio Guidi Drei (b. 1927) was born in Buenos Aires and studied in both Argentina and Italy. He worked as a director of studies, an assistant conductor, and a professor of music theory, solfeggio, and harmony. He composed the opera Medea to text based on the classical Greek myth about Medea. It premiered on 1 July 1973 at the Teatro Colón. ${ }^{288}$

Composer and orchestra director Juan Carlos Zorzi (1936-1999) composed the one-act opera El timbre, with a libretto by Javier Collazo. It was presented at the Teatro Argentino de La Plata on 6 August 1975. ${ }^{289}$ Zorzi composed another opera to a libretto by Javier Collazo, Antígona Vélez. It was based on a tragedy by Leopoldo Marechal, and includes the mythological character Antigone from Sophocles' writings. This three-act opera premiered at the Teatro Colón on 17 December $1991 .^{290}$

\footnotetext{
${ }^{286}$ Béhague, Music in Latin America: An Introduction, 338; Ficher, Furman Schleifer, and Furman, Latin American Classical Composers: A Biographical Dictionary, 402.

${ }^{287}$ Valenti Ferro, Historia de la ópera argentina, 52, 58, 62.

${ }^{288}$ Valenti Ferro, Historia de la ópera argentina, 55; Ficher, Furman Schleifer, and Furman, Latin American Classical Composers: A Biographical Dictionary, 196.

${ }^{289}$ Valenti Ferro, Historia de la ópera argentina, 55-56.

${ }^{290}$ Ibid., 60-61.
} 
Roberto García Morillo (1911-2003) was born in Buenos Aires. He studied with teachers such as Floro Ugarte and Constantino Gaito. He was a composer and a music critic for the Buenos Aires' newspaper La Nación. His only opera composition was El caso malliard, and he wrote the libretto based on an Edgar Allen Poe story. It opened at the Teatro Colón on 30 September $1977 . .^{291}$

Gerardo Gandini (1936-2013) was one of the most diverse and interesting Argentine musicians. La pasión de Buster Keaton was his first opera and he defined it as an "operamelodrama." The opera was based on the famous North American comic cinema actor of the 20s, Buster Keaton. Gandini's composition was primarily derived from the text of the surrealist poem by Spanish poet Rafael Alberti, "Buster Keaton busca a su novia," but also used texts by Lewis Carroll, Ranieri de Calzabigi, Paul Eluard, and Benjamín Péret. La pasión de Buster Keaton premiered on 27 June 1978 at the Instituto Goethe. ${ }^{292}$ La casa sin sosiego, with a libretto by Griselda Gambaro, was commissioned by the Instituto di Tella and the Fundación San Telmo. The opera premiered in the Teatro General San Martín on 27 June 1992, directed by the composer. ${ }^{293}$ Gandini's two-act opera, La ciudad ausente, was written to a libretto by Ricardo Piglia, based on a novel by Piglia himself. It was presented at the Teatro Colón on 24 October 1995. The opera follows the story of writer Macedonio Fernández, who can't bear the suffering brought on him by his wife's death. ${ }^{294}$

Augusto Benjamín Rattenbach (b. 1927) composed multiple operas. The first, Jettatore, premiered on 6 July 1980 at the Teatro del Libertador in Córdoba. The libretto was based on the

\footnotetext{
${ }^{291}$ Valenti Ferro, Historia de la ópera argentina, 56; Ficher, Furman Schleifer, and Furman, Latin American Classical Composers: A Biographical Dictionary, 172.

292 Valenti Ferro, Historia de la ópera argentina, 56-57.

293 Ibid., 62.

294 Ibid., 63-65.
} 
work of Gregorio de Laferrère. His next opera, Edipo en San Telmo, was a one-act chamber opera, with a libretto by Elena García de la Mata. It opened at the Teatro del Viejo Palermo on 29 September 1986. Minotauro was a chamber opera written to a libretto by Argentino Girolami and based on a book by José María Gómez. It was presented on 9 April 1994 in Alberdi del Teatro General San Martín. ${ }^{295}$

Horacio López de la Rosa (1933-1986) was born and studied in Buenos Aires. He composed La segunda vida, and wrote the libretto based on a story by Charles Asselineau. The opera premiered 7 March 1988 in the Anfiteatro Caminito, in the Buenos Aires neighborhood La Boca. ${ }^{296}$

Marta Lambertini (b. 1937) composed a chamber opera based on Lewis Carroll's novel Alice in Wonderland. Alicia en el país de las maravillas was presented on 7 April 1989 at the Instituto Goethe. This one-act opera was written in three languages, but primarily in English. Lambertini wanted to present a work with multiple levels of interpretation, just as in Carroll's story. His chamber opera, !Oh, Eternidad!, was presented at the Capilla de la Recoleta on 6 October 1990. A variety of sources were used to create the text for !Oh, Eternidad...! including works by Ana Magdalena Bach, Edgar Allan Poe, Friedrich Hölderin, and Marta Lambertini herself. $^{297}$

Alejandro Pinto (1922-1991) was an Argentine composer born in Poland. He moved to Argentina around the age of twelve-thirteen years old. He composed the opera Adonias, which premiered at the Teatro Colón on 19 December $1989 .{ }^{298}$

\footnotetext{
295 Ibid., 57, 62, 104.

${ }^{296}$ Valenti Ferro, Historia de la ópera argentina, 58; Ficher, Furman Schleifer, and Furman, Latin American Classical Composers: A Biographical Dictionary, 245.

297 Valenti Ferro, Historia de la ópera argentina, 58-59.

${ }^{298}$ Valenti Ferro, Historia de la ópera argentina, 59; Ficher, Furman Schleifer, and Furman, Latin American Classical Composers: A Biographical Dictionary, 327.
} 
Pianist, photographer, and composer Osías Wilenski (b. 1933) was born in Buenos Aires, and studied piano in Argentina and in the United States. He composed the chamber opera $L a$ venganza de Carmen, which premiered in $1990 .{ }^{299}$

Ernesto Mastronardi (b. 1927) was a pianist and composer of Argentine birth. He worked as the assistant conductor at the Teatro Colón and as a professor at the Instituto Superior de Arte of the Teatro Colón. He wrote the music and libretto for the opera La venganza de Don Mendo. This two-act opera was based on a work by Pedro Muñoz Seca. It opened on 7 April 1991 at the Teatro Presidente Alvear, during a season when the Teatro Colón was utilizing this hall. ${ }^{300}$ Martín Matalón (b. 1958) composed El milagro secreto based on a story by Jorge Luis Borges. This one-act chamber opera was presented in the Auditorio del Instituto Goethe on 29 June 1991. El milagro secreto had been previously performed in the "Opera Autrement" competition and in the Festival de Avignon in France on 12 July 1989. 301

Fernando González Casellas (1925-1998) wrote the opera Saverio el cruel (1996). He adapted the libretto from a theatrical work by Roberto Arlt. The plot develops around a group of high-class people that need someone innocent to provide them with entertainment. They choose Saverio, a humble vendor, as their victim. ${ }^{302}$

\footnotetext{
${ }^{299}$ Valenti Ferro, Historia de la ópera argentina, 59; Ficher, Furman Schleifer, and Furman, Latin American Classical Composers: A Biographical Dictionary, 440.

${ }^{300}$ Valenti Ferro, Historia de la ópera argentina, 60; Ficher, Furman Schleifer, and Furman, Latin American Classical Composers: A Biographical Dictionary, 264.

301 Valenti Ferro, Historia de la ópera argentina, 60.

302 Ibid., 66-67.
} 


\section{Chile: Operas and Composers}

The first attempt at a national Chilean opera was made by Aquinas Ried, who was born in Germany between 1810 and 1813 . He relocated to Chile, where he later died in 1869 . Ried composed several operas: La Telésfora, Il grenatiere, Walhalla, Diana, Ismenilda, Idona, Ondega, and Atacama. He composed La Telésfora in 1846 and hoped to present it in a celebration in September of that year, however that did not happen. ${ }^{303}$ The opera was listed in a program for the lyric company Pantanelli as "the opera written in Spanish by Mr. Reid."304 The plot of the opera was inspired by the war of independence. Pelayo, a captain, is secluded and living in a cave after the Spanish reconquest. His sister-in-law, Telésfora, and his niece, Irene, are with him. Gonzalo, an official, is going to offer them his protection, but his love for Irene and Pelayo's intense speeches lead him to abandon the King's cause. Tragic moments in the campaign for liberation come. Pelayo is hurt in battle, Telésfora cares for his wound, and attacks the enemy. Pelayo dies, and at that moment, Irene and Gonzalo embrace, a symbol of the beginning of a new period. The libretto of La Telésfora was published in 1846. The premiere that was to occur in September 1846, eventually took place in 1885 , in Valdivia. ${ }^{305}$

\footnotetext{
${ }^{303}$ Eugenio Pereira Salas, Los orígenes del arte musical en Chile (Santiago, Chile, Universitaria, 1941), 131; Ficher, Furman Schleifer, and Furman, Latin American Classical Composers: A Biographical Dictionary, 348.

${ }^{304}$ Pereira Salas, Los orígenes del arte musical en Chile, 136.

${ }^{305}$ Pereira Salas, Los orígenes del arte musical en Chile, 136.
} 


\section{Colombia: Operas and Composers}

There were only two operas presented in Bogotá in the nineteenth century, both written by José María Ponce de León (1846-1882): Ester (1874) and Florinda (1880). ${ }^{306}$ The libretto for Ester was written by Rafael Pombo and Manuel Briceño. Pombo also wrote the libretto for Florinda. ${ }^{307}$ Ester's libretto was originally written in Spanish, sung in Italian, and printed in a bilingual version (Spanish/Italian) for the premiere. It was tradition for the singers to present an opera in their native language, and the cast that premiered the opera consisted of Italian singers, making it natural for them to present the opera in Italian. ${ }^{308}$

Opera was identified as an Italian name for an Italian musical genre, sung in Italian. Pombo expressed a desire to hear his opera presented in its original version: "Hopefully, the company will decide to give us Ester in Spanish, like it was written. It has been sung many times in Italian, its success was an ovation, and we believe that today, in Bogotá, there are hundreds that long to hear it, and there are hundreds that will delight in returning to hear it." 309

\section{Paraguay: Operas and Composers}

Two mission operas were found by musicologists among sheet music that was transferred from several small mission towns to Concepción, Bolivia. The sheet music came from more than thirty towns that formed the Paraguay province when Jesuits were prominent in the area. The

\footnotetext{
306 Béhague, Music in Latin America: An Introduction, 160.

${ }^{307}$ Carolina Alzate and Rondy Torres, José María Ponce de León y la ópera en Colombia en el siglo XIX \& Ester (Bogotá, Colombia, Universidad de los Andes, Facultad de Artes y Humanidades, Departamento de Música), 7-8. ${ }^{308}$ Alzate and Torres, José María Ponce de León y la ópera en Colombia en el siglo XIX \& Ester, 5-6.

309 Ibid., 6.
} 
operas found were San Ignacio de Loyola (1717-1727) and San Francisco Xavier (17201730). ${ }^{310}$

San Ignacio de Loyola was written by the Italian-born Argentine composer Domenico Zipoli (1688-1726). The opera tells the story of the founders of the Company of Jesus, San Ignacio Loyola and Francis Xavier. The musical score survived and the libretto reveals that the opera was presented by indigenous actors and musicians. Recitative, arias, choruses, and dances are all present in the opera score. San Ignacio de Loyola is an important work because it provides evidence of collaboration between Europeans and indigenous people. The opera was written in Spanish, but included text written in the indigenous Chiquitano language. ${ }^{311}$

San Francisco Xavier was written by an unknown indigenous composer. The opera portrays the story of Saint Xavier and his reunion in heaven with the Jesuit founder, Saint Ignatius. The libretto was written entirely in the native Chiquitano language, and the opera was probably performed by indigenous people. San Francisco Xavier could be the earliest opera in an indigenous language (pending potential future discoveries). ${ }^{312}$

\section{Peru: Operas and Composers}

Tomás de Torrejón y Velasco (1644-1728) was born in Spain and moved to Peru. He composed the first opera in the New World, La púrpura de la rosa (1701), which was commissioned by the Viceroy, Conde de la Monclova. The opera was presented for King Philip

\footnotetext{
${ }^{310}$ Gasta, Transatlantic Arias: Early Opera in Spain and the New World, 88.

${ }^{311}$ Ibid., 88-90.

${ }^{312}$ Ibid., 89.
} 
V's eighteenth birthday and in honor of his first year of reign in Spain. ${ }^{313}$ Torrejón used the opera libretto that Pedro Calderón wrote in 1660 for Juan Hidalgo's opera of the same name. ${ }^{314}$ The December 1701 production of La púrpura de la rosa, at the viceregal palace in Lima, was the first presentation of a Spanish libretto in the eighteenth century. ${ }^{315}$

The plot of La púrpura de la rosa is based on the myth of Venus and Adonis. However, Calderón adds to the myth by including main characters for comic relief; such as a soldier, a peasant, and his wife. A loa, or an additional composition, precedes the opera and uses separate text than Calderón's libretto. The loa utilizes solo, duet, and four-part chorus. The one-act opera consists of solo songs with short choral pieces interspersed between the solos. Torrejón created a refrain-like theme for the main characters: Adonis, Mars, and Venus. The theme is usually heard at the opening of a scene and is used to signal the presence of that character throughout the scene. One of the most demanding roles is that of Adonis. The level of difficulty stems from the range, length of the part, and the required melodic elaboration ("large intervallic skips, chromaticism, motivic imitation, rapid figuration"). ${ }^{316}$

Torrejón's accompaniment is a single continuo line. The bass at times is an imitation of the vocal line, and other times independent. It is unknown which instruments were used to realize the continuo, but it was likely strings with either harpsichord or harp. There are indications in the score that there were trumpets and drums used offstage. Torrejón was conscientious in his text setting, using harmonic, melodic, and rhythmic material to support the lyrics and to stress the meaning of different words. ${ }^{317}$

\footnotetext{
${ }^{313}$ Robert Stevenson, Foundations of New World Opera (Lima, Peru, Ediciones “CVLTVRA,” 1973), 48; Béhague, Music in Latin America: An Introduction, 63-64.

${ }^{314}$ Béhague, Music in Latin America: An Introduction, 64.

${ }^{315}$ Louise K. Stein and José Máximo Leza, “Opera, genre, and context in Spain and its American colonies,” 245.

${ }^{316}$ Béhague, Music in Latin America: An Introduction, 64.

${ }^{317}$ Ibid., 64.
} 
The first locally-composed opera in Spanish, presented at the viceregal palace, was $E l$ robo de Proserpina y sentencia de Júpiter by Filippo Coppola. It was performed at the palace on 2 February $1678 . .^{318}$

Roque Ceruti was a Peruvian composer, a native of Milan, Italy, and chapelmaster in Lima (he succeeded Torrejón). He composed the opera El mejor escudo de Perseo (1708), with a libretto by Manuel de Oms y de Santa Pau. The opera was presented in the Viceroy's palace garden in honor of the birth of Crown Prince Luis. Both recitative and arias were used in the opera. $^{319}$

Pedro Peralta Barnuevo (1664-1743) composed Triunfos de amor y poder (1711). The opera was written to celebrate the French victory at Villaviciosa, in 1710, that secured the Spanish throne for Philip V. Triunfos de amor y poder set to music a loa, dances, a satirical theatrical piece, and a bullfight. The opera used arias, choruses, and recitative. ${ }^{320}$

Carlo Enrique Pasta (1855-1898) was an Italian composer that wrote the first opera focused on a Peruvian story, Atahualpa (1877). Its premiere took place in Lima. The compositional style used in the opera embraced a musical nationalism that focused on the collection and harmonization of Peruvian folk songs. ${ }^{321}$

José María Valle Riestra (1859-1925) was a composer that is most remembered for his opera Ollanta. The opera was written during Chilean army occupation in Peru and was a way of responding to the pain experienced during that time. Valle Riestra explained, "our armies were already defeated and discouraged for the disgrace and for the position of our patriotic impetus. I had to look for something soothing in music in order to quell those hours of despair and

\footnotetext{
318 Stevenson, Foundations of New World Opera, 46.

${ }^{319}$ Gasta, Transatlantic Arias: Early Opera in Spain and the New World, 85-86.

${ }^{320}$ Ibid., 86.

${ }^{321}$ Béhague, Music in Latin America: An Introduction, 165.
} 
anxiety." 322 Federico Blume wrote the libretto for Ollanta, that in its first version, premiered on

26 December 1900, but it was not as successful as expected. Despite local fondness for opera and the participation of singers from the Italian Company Lombardi, public attendance of the opera was poor. Ollanta was described in a local journal, El Comercio, as a national opera that underwent "a thousand deprivations and sacrifices, infinite fights, and silent tears to be produced and offered to the people of Lima. It was an audacity because the opera was performed in a desert." 323

Valle Riestra later revised Ollanta and added elements that reminded him of Verdi's Aida. With the revision of the music, he added to the libretto with text of Luis Fernán Cisneros. The revised version of Ollanta was presented at the Teatro Forero in 1920 by the Italian Company Bracale, and was directed by Alfredo Padovani. The scenery was made from sketches by the painter José Sabogal. It was well-received by both the public and the critics. Valle Riestra also composed the first act of an opera, Atahualpa. ${ }^{324}$

\section{Uruguay: Operas and Composers}

Tomás Giribaldi (1847-1930) composed La Parisina (1878) and Manfredi di Svevia (1882). ${ }^{325}$ La Parisina was the first Uruguayan opera, and it premiered at the Teatro Solis in 1878. La Parisina is a tragic opera based on a libretto by Felice Romani. It has a prologue and

\footnotetext{
${ }^{322}$ Armando Sánchez Málaga, Nuestros otros ritmos y sonidos: la música clásica in el Peru (Lima, Peru, Fondo Editorial del Congreso del Perú, 2012), 250; Ficher, Furman Schleifer, and Furman, Latin American Classical Composers: A Biographical Dictionary, 423.

${ }^{323}$ Sánchez Málaga, Nuestros otros ritmos y sonidos: la música clásica in el Peru, 250.

${ }^{324}$ Ibid., 252.

${ }^{325}$ Susana Salgado, Breve historis de la música culta en el Uruguay (Montevideo, Uruguay, A. Monteverde y Cia S.A., 1980), 17; Ficher, Furman Schleifer, and Furman, Latin American Classical Composers: A Biographical Dictionary, 180.
} 
three acts, and the music includes leitmotifs, arias, a quartet, a vocal and instrumental fugue, and a funeral march. The opera was immediately successful in the eyes of critics and the public. ${ }^{326}$

Madfredi di Svevia opened at the Teatro Solis 18 July 1882, in celebration of the anniversary of the Constitution. The libretto was written by José Emilio Ducati, based on a novel by Guerrazzi. The plot is set in 1625, in the outskirts of Naples. The opera is five acts long and uses extensive amounts of recitative. This opera was not as well received as his first opera, and Giribaldi decided not to further pursue opera composition. ${ }^{327}$

Carlos Pedrell (1878-1941) was born in Uruguay, and was a nephew of the famed Spanish composer Felipe Pedrell. Although he is considered an Uruguayan composer, he spent most of his career in Argentina. He composed Ardid de amor, which was a lyric comedy in one act, with a libretto written by Tristán Klingsor. It premiered on 7 June 1917 in the Teatro Colón. ${ }^{328}$ Pedrell also composed the opera La guitarra, with a libretto by Xavier Courville, which opened at the Teatro Odeón on 18 September $1924 .{ }^{329}$

Enrique Mario Casella (1891-1948) was born in Uruguay and later settled in Argentina, ${ }^{330}$ where he lived out his artistic career. ${ }^{331}$ He premiered his opera Corimayo at the Teatro Alberdi de San Miguel de Tucumán on 20 September 1926. Its Buenos Aires’ premiere took place at the Teatro Avenida. ${ }^{332}$ La tapera, an opera in three acts, opened at the Teatro Cervantes on 13 November 1934. The artistic director was composer Alfredo L. Schiuma. ${ }^{333}$

\footnotetext{
326 Salgado, Breve historis de la música culta en el Uruguay 51, 77-78.

327 Ibid., 79-80.

${ }^{328}$ Valenti Ferro, Historia de la ópera argentina, 28.

${ }^{329}$ Ibid., 37.

${ }^{330}$ Some sources list Enrique Mario Casella as an Argentine composer.

331 Some sources refer to Enrique Mario Casella as an Argentine composer, and others as an Uruguayan composer.

332 Valenti Ferro, Historia de la ópera argentina, 38.

333 Ibid., 42.
} 
Chasca was presented on 29 August 1939 at the Teatro Alberti. Casella herself also wrote the libretto, and set the drama in the province of Catamarca, in the center of an Incan tribe. ${ }^{334}$

\section{Venezuela: Operas and Composers}

José Ángel Montero (1832-1881) was a composer and musician. He played several instruments, with his favored instrument being the flute. He composed the opera Virginia, which premiered in April 1873. ${ }^{335}$

\footnotetext{
${ }^{334}$ Ibid., 45.

${ }^{335}$ Gustavo Batista, Felipe Gutiérrez y Espinosa (1825-1899): Y el ambiente musical en el San Juan de su época (San Juan, Puerto Rico, BiblioGráficas, 2015), 46; Ficher, Furman Schleifer, and Furman, Latin American Classical Composers: A Biographical Dictionary, 281.
} 


\section{Chapter 5: Central America and the Caribbean}

The only Central American country with information about a national opera is Guatemala. Consequently, it is the only Central American nation discussed in this research document. The Caribbean countries included in this research document are the Spanish-speaking nations of Cuba, the Dominican Republic, and Puerto Rico. Of these countries, Cuba provides the majority of Caribbean national operas, with the other countries having only a small number of national operas. Although the output of operas in Cuba is greater than that of other countries, the success of these operas varied. ${ }^{336}$ In the nineteenth century, Italian and French operas were prominent in Cuban theaters, such as the Teatro Principal, the Teatro Tacón, and the Liceo Artístico y Literario, as well as in concert halls. ${ }^{337}$ Although foreign operas maintained their popularity, musical nationalism began to emerge in Cuba in the late nineteenth and early twentieth centuries. ${ }^{338}$

\section{Cuba: Operas and Composers}

Manuel Saumell Robredo (1817-1870) was a Cuban pianist and composer. He wanted to compose the first Cuban national opera. The opera that he imagined was set in Cuba in 1590. It involved a workforce of black slave laborers, indigenous people, Italian and Spanish people, a sugar mill, a ball game, Havana neighborhoods, and other people, places, and situations that

\footnotetext{
${ }^{336}$ Alejo Carpentier, Music in Cuba (Minneapolis, MN, Regents of the University of Minnesota, 2001 ), 254.

${ }^{337}$ Béhague, Music in Latin America: An Introduction, 102.

${ }^{338}$ Bethell, A Cultural History of Latin America: Literature, Music and the Visual Arts in the $19^{\text {th }}$ and $20^{\text {th }}$ Centuries, 312.
} 
would fit a nationalistic theme. He wanted to cast indigenous people and blacks in his opera, something that was not done at that time..$^{339}$

Saumell Robrido sought a poet to write an Italian libretto for his opera, because there was only one company in Havana that could potentially produce the opera, and it was an Italian company. However, the response he received was not a favorable one, because it was generally thought that writing an opera based on Cuban life and ideals was preposterous. He was discouraged by this news, as well as by the end of his relationship with singer Dolores de SaintMaxent, his original inspiration for writing the opera. He abandoned all attempts at bringing this opera to fruition and of composing the first Cuban national opera. ${ }^{340}$

Laureano Fuentes Matons (1825-1898) was a violinist and composer, born in Santiago de Cuba. He was an active performer, founder of the musical journal La lira cubana, and professor at the Colegio of Santiago de Cuba. He composed the first opera written in Cuba, La hija de Jefté (1875), which was later expanded and produced under a new title, Seila. ${ }^{341}$

Cristóbal Martínez Corres (1822-1842), a Cuban composer living in Europe, had completed an opera by the time he was eighteen years old, El diablo contrabandista. He wrote a second opera, Don Papaner o la burla del hipnotismo, and started another opera, Saffo. He died before he was able to finish his third opera. None of his works have survived. ${ }^{342}$

Cuban composer Eduardo Sánchez de Fuentes (1874-1944) also decided to compose a national opera. Yumuri opened in October 1898 at the Alibsu Theater, with a libretto written by Rafael Fernández de Castro. The two-act opera includes characters such as the daughter of an

\footnotetext{
${ }^{339}$ Carpentier, Music in Cuba 187-188.

340 Ibid., 189.

${ }^{341}$ Carpentier, Music in Cuba 236; Ficher, Furman Schleifer, and Furman, Latin American Classical Composers: A Biographical Dictionary, 165.

342 Carpentier, Music in Cuba 239.
} 
Indian chief, a conquistador, a chief of a tribe, and a priest. The plot involves romance between a white man and an indigenous woman, who are prevented from being together by tribal religious traditions. The finale incorporates an earthquake and a toppling mountain, and the score contains arias, duets, and instrumental sections. It was the first opera based on a national story, however the indigenous aspect of the music was created theoretically as there were no pure musical examples or resources for Cuban indigenous music. ${ }^{343}$

El náufrago was a two-act opera composed by Sánchez de Fuentes in 1901, with a plot based on Tennyson's Enoch Arden. The opera was highly successful and popular with audiences. He composed another opera, La Dolorosa, that premiered 8 August 1911 at the Balbo Theater in Turin, Italy. The libretto was written by Federico Uhrbach. It utilizes contemporary characters dressed in formal and sports attire, and the setting involves "trendy beaches and millionaire gardens." The plot ends with the death of a suicidal wife. ${ }^{344}$

Doreya was composed by Sánchez de Fuentes, with a libretto by Hilarión Cabrisas, and with the idea of presenting nationalism in opera. The opera premiered in February 1918. He remade his previous opera, Yumurí, with a new libretto. He renewed ideas of indigenous themes and composed an areito (a ceremonial dance) for inclusion in the opera that included "Indians sounding drums, conch shells, and horns, dancing in an archaeologically precise way." 345

José Mauri Esteve (1856-1937) was a Cuban composer, born in Valencia. His opera, La esclava, with a libretto by Tomás Juliá, premiered in Havana on 6 June 1921. The opera was set in 1860, in a sugar mill in Camagüey. One of the main characters is the daughter of a slave, naïve to her family's background. Among the secondary characters are blacks, guajiros, and hunters.

\footnotetext{
${ }^{343}$ Ibid., 250-251.

${ }^{344}$ Ibid., 251-252.

${ }^{345}$ Ibid., 252.
} 
He incorporated ideas of folk music and rhythm: "the habanera, the criolla, the danzón, and the rumba" were all integrated in the music. He also created a leitmotif with an Afro-Cuban theme. ${ }^{346}$

Gaspar Villate (1851-1892) was born in Havana, and later lived in both the United States and France. He composed three operas that successfully premiered in Europe: Zilia premiered in Paris in 1877, La czarina premeried in La Haya in 1880, and Baltazar premiered in Madrid in 1885. Other opera compositions included Angelo, tirano de Padua (1867), Las primeras armas de Richelieu (1871), Cristóforo Colombo (1884-1886), and Lucifer (1887-1889) ${ }^{347}$

\section{Dominican Republic: Operas and Composers}

Pablo Claudio (1855-1899) was born in Azua in the Dominican Republic. He was a clarinetist and composer. He composed two operas, América and María de Cuéllar. ${ }^{348}$

\section{Guatemala: Operas and Composers}

Jesús Castillo (1877-1946) was particularly interested in the musical folklore of Guatemala. He was a composer and folklorist, and composed the operas Quiché Vináte (19191924) and Nicté (1936). ${ }^{349}$

\footnotetext{
${ }^{346}$ Carpentier, Music in Cuba, 254-255.

${ }^{347}$ Batista, Felipe Gutiérrez y Espinosa (1825-1899): Y el ambiente musical en el San Juan de su época, 44; Ficher, Furman Schleifer, and Furman, Latin American Classical Composers: A Biographical Dictionary, 436.

${ }^{348}$ Batista, Felipe Gutiérrez y Espinosa (1825-1899): Y el ambiente musical en el San Juan de su época, 42; Ficher, Furman Schleifer, and Furman, Latin American Classical Composers: A Biographical Dictionary, 114.

${ }^{349}$ Ficher, Furman Schleifer, and Furman, Latin American Classical Composers: A Biographical Dictionary, 102.
} 


\section{Puerto Rico: Operas and Composers}

Felipe Gutiérrez (1825-1899) was the chapelmaster at the Cathedral of San Juan, and composed an opera in two acts, Amor de un pescador. He composed three additional operas:

Guarionex, El bearnés, and Macías. ${ }^{350}$

${ }^{350}$ Batista, Felipe Gutiérrez y Espinosa (1825-1899): Y el ambiente musical en el San Juan de su época, 48; Ficher, Furman Schleifer, and Furman, Latin American Classical Composers: A Biographical Dictionary, 199. 


\section{Chapter 6: Conclusion}

Opera was both composed and performed in Spain and Latin America, and both regions demonstrate the development of national opera traditions. The output varies by country, with Spain, Mexico, and Argentina claiming the majority of operas from Spanish-speaking countries. Spanish drama was closely linked to the beginnings of national opera, and Italian influence is evident in opera compositions from Spain and Latin America. Composers often studied internationally and were affected by European compositional techniques and traditions. Many national operas include various native elements in the composition, but also demonstrate the influence of Italian opera traditions. Operas composed in a Spanish or Latin American musical style, usually still included a libretto written in Italian and were regularly performed by Italian opera troupes.

Italian opera was extremely popular in both Spain and Latin American countries. This is evident in compositions, performances, reviews, and writings about opera in these nations. There are multiple sources about opera in a particular Spanish-speaking country that only discuss productions of foreign opera, primarily Italian with some French and/or German as well. While there is a plethora of information about these Italian opera performances, including the singers that performed the operas, and each production of the operas in various theaters, information about national operas and composers is more limited. This can be for several reasons. It can be linked to available literature and access to this literature, as well as the records that were kept. Even when there is information and evidence of the existence of a particular opera, the score is often lost or no longer in existence. National operas also developed at a slower pace and were thwarted by the popularity of Italian opera, leading to fewer national opera compositions, fewer 
productions of those works, and less surviving information about them. Despite the challenges faced by composers of national operas, these operas were created, sometimes produced, and evidence of them exists.

The research for this document is based on sources that are available through the West Virginia University library, either directly or through an interlibrary loan from a partner library. Some online databases and electronic resources have been utilized as well. The majority of the books and articles accessed were written in Spanish and published in Spain or a Latin American country, although there are some sources available in English. It is possible that other sources on this topic are available in other locations, some in libraries and archives in the United States. However, most sources would likely be in the composer's country of origin, the country where the opera was written and/or produced, in libraries, theaters, archives, and/or in documents belonging to composers and their descendants. It is also probable that potential sources are written in Spanish.

This research document is not all inclusive. It does provide a resource, written in English, of opera in Spain and Latin America. Included is every opera title and opera composer that was encountered in this research, from the initial development of each country's national opera through the twentieth century. Musical information and material about the text and librettist is also included when available. The information in this document provides a framework and potential for further research in the topic of opera in Spain and Latin America, as well as allowing English speakers to access information that in some cases, has only been available to Spanish speakers. Based on the sources and information accessed, this document is the first of its type, in English or in Spanish, to compile this information about opera in Spain and Latin America in one location. 


\section{Appendix A: \\ Spain: Operas in Chronological Order}

\begin{tabular}{|c|c|}
\hline Year & Title \\
\hline 1629 & La selva sin amor \\
\hline 1660 & Celos aun del aire matan \\
\hline 1660 & La púrpura de la rosa \\
\hline 1760 & Antigono \\
\hline 1762 & Temistocle \\
\hline 1774 & Sesostri \\
\hline 1781 & Ifigenia in Aulide \\
\hline 1845 & Padilla, o El asedio de Medina \\
\hline 1849 & Ildegonda \\
\hline 1850 & La conquista de Granada \\
\hline 1851 & El campamento \\
\hline 1871 & Marina \\
\hline 1889 & Los amantes de Teruel \\
\hline 1890-1893 & Henri Clifford \\
\hline 1890-1893 & The Magic Opal \\
\hline 1892 & Garin \\
\hline 1895 & La Dolores \\
\hline 1897 & Artús \\
\hline 1897 & La sulamita \\
\hline 1900 & Eda d'Uriach \\
\hline 1902 & Acté \\
\hline 1902 & Raimundo Lulio \\
\hline 1903 & Juana de Nápoles \\
\hline 1904 & La Celestina \\
\hline 1904 & La devoción de la Cruz \\
\hline 1905 & La vida breve \\
\hline 1906 & Emporium \\
\hline 1906 & La prisión de Lérida \\
\hline 1908 & Bruniselda \\
\hline 1910 & Canigó \\
\hline 1910 & El final de Don Alvaro \\
\hline 1910 & Mendi-Mendiyan \\
\hline 1910 & Mirentxu \\
\hline 1910 & Yolanda \\
\hline 1911 & La tragedia del beso \\
\hline 1913 & Gala Placidia \\
\hline
\end{tabular}

\section{Composer}

Piccinini, Filippo

Hidalgo, Juan

Hidalgo, Juan

Durán, José

Durán, José

Terradellas, Domènec

Martín y Soler, Vicente

Espín y Guillén, Joaquín

Arrieta, Emilio

Arrieta, Emilio

Inzenga, José

Arrieta, Emilio

Bretón, Tomás

Albéniz, Isaac

Albéniz, Isaac

Bretón, Tomás

Bretón, Tomás

Vives, Amadeo

Turina, Joaquín

Vives, Amadeo

Manén, Joan

Villa, Ricardo

Manén, Joan

Pedrell, Felipe

Morera, Enric

Falla, Manuel de

Morera, Enric

Pahissa, Jaime

Morera, Enric

Pahissa, Jaime

Campo, Corado del

Usandizaga, José María

Guridi, Jesús

Arregui, Vicente

Campo, Corado del

Pahissa, Jaime

\section{Librettist}

Vega, Lope de Calderón, Pedro

Calderón, Pedro

Metastasio

Money-Coutts, Francis Burdett Money-Coutts, Francis Burdett
Fernández Shaw, Carlos

Fernández Shaw, Carlos

Echave, Alredo

Fernández Shaw, Carlos 


\begin{tabular}{|c|c|c|c|}
\hline 1914 & Amor vedado & Gaos, Andrés & \\
\hline 1914 & Las sombras del bosque & Calés Pina, Francisco & \\
\hline 1916 & Goyescas & Granados, Enrique & \\
\hline 1917 & Himno de amor & Gómez, Julio & Delgado, Sinesio \\
\hline 1918 & El Avapiés & Campo, Corado del & Borrás, Tomás \\
\hline 1919 & La morisca & Pahissa, Jaime & \\
\hline 1920 & Amaya & Guridi, Jesús & Jáuegui, José María \\
\hline 1921 & Don Joan de Serrallonga & Morera, Enric & \\
\hline 1921 & El mestre & Morera, Enric & \\
\hline 1922 & 1833 & Franco Bordóns, José María & \\
\hline 1922 & Fantochines & Campo, Corado del & Borrás, Tomás \\
\hline 1922 & Jardin de oriente & Turina, Joaquín & \\
\hline 1923 & Marianela & Pahissa, Jaime & \\
\hline 1924 & El miserere de la montaña & Calés Pina, Francisco & \\
\hline 1924 & La virgen de Mayo & Moreno Torroba, Federico & \\
\hline 1925 & El pelele (chamber opera) & Gómez, Julio & $\begin{array}{l}\text { Rivas Cherif, } \\
\text { Cipriano }\end{array}$ \\
\hline 1925 & La malquerida & Campo, Corado del & $\begin{array}{l}\text { Romero, Federico, } \\
\text { and Fernández } \\
\text { Shaw, Guillermo }\end{array}$ \\
\hline 1927 & Los dengues (chamber opera) & Gómez, Julio & $\begin{array}{l}\text { Rivas Cherif, } \\
\text { Cipriano }\end{array}$ \\
\hline 1928 & Cantuxa & Baudot, Gregorio & \\
\hline 1928 & El giravolt de maig & Toldrá, Eduard & \\
\hline 1928 & La princesa Margarida & Pahissa, Jaime & \\
\hline 1933 & Charlot & Bacarisse, Salvador & \\
\hline 1938 & Angelica & Pahissa, Jaime & \\
\hline 1943 & La filla del rey barbut & Salvador, Matilde & \\
\hline 1944 & El pilar de la victoria & Gómez, Julio & Machado, Manuel \\
\hline 1948 & El gato con botas & Montsalvatge, Xavier & \\
\hline 1948 & El mozo que casó con mujer brava & Suriñach, Carlos & \\
\hline 1948 & Nuredduna & Massana, Antonio & \\
\hline 1949 & Lola, la piconera & Campo, Corado del & Pemán, José María \\
\hline 1952 & El castell dirós I non tornarás & Mas Porcel, Jaime & \\
\hline 1952 & Soledad & Manén, Joan & \\
\hline 1953 & Canigó & Massana, Antonio & \\
\hline $1953-1956$ & Moros & Palau, Manuel & \\
\hline 1955 & Don Gil de las calzas verdes & Pahissa, Jaime & \\
\hline 1956 & Mar de invierno & Gómez, Julio & Muñoz, Matilde \\
\hline 1956 & Tragicomedia de Calixto y Melibea & Pahissa, Jaime & \\
\hline 1958 & La mona de imitación & Arteaga, Angel & $\begin{array}{l}\text { Serna, Ramón } \\
\text { Gómez de la }\end{array}$ \\
\hline 1959 & El ganxo & $\begin{array}{l}\text { Mestres-Quadreny, Josep } \\
\text { María }\end{array}$ & \\
\hline 1960 & Agammenon & Soler, Josep & \\
\hline 1960 & El terrible entrevistador & Arteaga, Angel & $\begin{array}{l}\text { Serna, Ramón } \\
\text { Gómez de la }\end{array}$ \\
\hline 1962 & Fuenteovejuna & Bacarisse, Salvador & \\
\hline 1962 & Una voz en off & Montsalvatge, Xavier & \\
\hline 1963 & Zigor & Escudero, Francisco & \\
\hline $1965-1973$ & Los bárbaros & Barce, Ramón & \\
\hline
\end{tabular}




\begin{tabular}{|c|c|c|c|}
\hline 1972 & Edipo y Yocasta & Soler, Josep & \\
\hline 1973 & Vinatea & Salvador, Matilde & \\
\hline 1979 & El poeta & Moreno Torroba, Federico & \\
\hline 1981 & Kiu & Pablo, Luis de & \\
\hline 1982 & Hangman, Hangman! & Balada, Leonardo & Balada, Leonardo \\
\hline 1984 & Zapata & Balada, Leonardo & \\
\hline 1984-1988 & El viajero indiscreto & Pablo, Luis de & \\
\hline 1986 & Christopher Columbus & Balada, Leonardo & Gala, Antonio \\
\hline 1986 & Gernika & Escudero, Francisco & \\
\hline 1992 & La madre invita a comer & Pablo, Luis de & \\
\hline 1996 & $\begin{array}{l}\text { The Death of Christopher } \\
\text { Columbus }\end{array}$ & Balada, Leonardo & Balada, Leonardo \\
\hline 1997 & The Town of Greed & Balada, Leonardo & Balada, Leonardo \\
\hline 1997-1999 & La señorita Cristina & Pablo, Luis de & \\
\hline * & Pepita Jiménez & Albéniz, Isaac & $\begin{array}{l}\text { Money-Coutts, } \\
\text { Francis Burdett }\end{array}$ \\
\hline$*$ & El cuento de Barba Azul & Arregui, Vicente & \\
\hline$*$ & La Madona & Arregui, Vicente & \\
\hline$*$ & La Maya & Arregui, Vicente & \\
\hline * & Circe & Chapí, Ruperto & \\
\hline$*$ & La bruja & Chapí, Ruperto & \\
\hline * & Margarita la Tornera & Chapí, Ruperto & \\
\hline * & Roger de Flor & Chapí, Ruperto & \\
\hline$*$ & El anillo de Polícrates & Echevarría, Victorino & \\
\hline$*$ & La dueña & Gerhard, Roberto & \\
\hline * & Heros & Manén, Joan & \\
\hline$*$ & Medea & Manén, Joan & \\
\hline$*$ & Nerón & Manén, Joan & \\
\hline * & El árbol de Diana & Martín y Soler, Vicente & \\
\hline$*$ & La cosa rara & Martín y Soler, Vicente & \\
\hline$*$ & Tasarba & Morera, Enric & \\
\hline$*$ & Becqueriana & Rodrigo, María & Quintero brothers \\
\hline$*$ & Canción de amor & Rodrigo, María & \\
\hline$*$ & Diana cazadora & Rodrigo, María & \\
\hline$*$ & La flor de la vida & Rodrigo, María & \\
\hline$*$ & La romería del Rocío & Rodrigo, María & \\
\hline$*$ & Almas muertas & Viña, Facundo de la & \\
\hline$*$ & La espigadora & Viña, Facundo de la & \\
\hline$*$ & La montaraza de Grandes & Viña, Facundo de la & \\
\hline * & La princesa flor de roble & Viña, Facundo de la & \\
\hline
\end{tabular}

* The date of composition was not found for this opera. 


\section{Appendix B: \\ Spain: Operas and Composers}

\section{Composer}

Albéniz, Isaac

Arregui, Vicente

Arrieta, Emilio

Arteaga, Angel

Bacarisse, Salvador

Balada, Leonardo

Barce, Ramón

Baudot, Gregorio

Bretón, Tomás

\author{
Title
}

Pepita Jiménez

Henri Clifford

The Magic Opal

El cuento de Barba Azul

La Madona

La Maya

Yolanda

Ildegonda

La conquista de Granada

Marina

La mona de imitación

El terrible entrevistador

Charlot

Fuenteovejuna

Hangman, Hangman!

Zapata

Christopher Columbus

The Death of Christopher

Columbus

The Town of Greed

Los bárbaros

Cantuxa

Los amantes de Teruel

Garín

La Dolores

Las sombras del bosque

El miserere de la montaña
Librettist

Year $\begin{array}{ll}\text { Money-Coutts, Francis } & * \\ \text { Burdett } & \\ \begin{array}{l}\text { Money-Coutts, Francis } \\ \text { Burdett }\end{array} & 1890-1893 \\ \begin{array}{l}\text { Money-Coutts, Francis } \\ \text { Burdett }\end{array} & 1890-1893\end{array}$

$*$

$*$

*

1910

1849

1850

1871

Serna, Ramón Gómez de 1958 la

Serna, Ramón Gómez de 1960 la

1933

1962

Balada, Leonardo 1982

1984

Gala, Antonio

1986

Balada, Leonardo

1996

Balada, Leonardo

1997

1965-1973

1928

1889

1892

1895

1914

1924 


\begin{tabular}{|c|c|c|c|}
\hline \multirow[t]{6}{*}{ Campo, Corado del } & El final de Don Alvaro & Fernández Shaw, Carlos & 1910 \\
\hline & La tragedia del beso & Fernández Shaw, Carlos & 1911 \\
\hline & El Avapiés & Borrás, Tomás & 1918 \\
\hline & Fantochines & Borrás, Tomás & 1922 \\
\hline & La malquerida & $\begin{array}{l}\text { Romero, Federico, and } \\
\text { Fernández Shaw, } \\
\text { Guillermo }\end{array}$ & 1925 \\
\hline & Lola, la piconera & Pemán, José María & 1949 \\
\hline \multirow[t]{4}{*}{ Chapí, Ruperto } & Circe & & $*$ \\
\hline & La bruja & & $*$ \\
\hline & Margarita la Tornera & & $*$ \\
\hline & Roger de Flor & & $*$ \\
\hline \multirow[t]{2}{*}{ Durán, José } & Antigono & Metastasio & 1760 \\
\hline & Temistocle & & 1762 \\
\hline Echevarría, Victorino & El anillo de Polícrates & & $*$ \\
\hline \multirow[t]{2}{*}{ Escudero, Francisco } & Zigor & & 1963 \\
\hline & Gernika & & 1986 \\
\hline Espín y Guillén, Joaquín & Padilla, o El asedio de Medina & & 1845 \\
\hline Falla, Manuel de & La vida breve & Fernández Shaw, Carlos & 1905 \\
\hline $\begin{array}{l}\text { Franco Bordóns, José } \\
\text { María }\end{array}$ & 1833 & & 1922 \\
\hline Gaos, Andrés & Amor vedado & & 1914 \\
\hline Gerhard, Roberto & La dueña & & $*$ \\
\hline \multirow[t]{5}{*}{ Gómez, Julio } & Himno de amor & Delgado, Sinesio & 1917 \\
\hline & El pelele (chamber opera) & Rivas Cherif, Cipriano & 1925 \\
\hline & Los dengues (chamber opera) & Rivas Cherif, Cipriano & 1927 \\
\hline & El pilar de la victoria & Machado, Manuel & 1944 \\
\hline & Mar de invierno & Muñoz, Matilde & 1956 \\
\hline Granados, Enrique & Goyescas & & 1916 \\
\hline \multirow[t]{2}{*}{ Guridi, Jesús } & Mirentxu & Echave, Alredo & 1910 \\
\hline & Amaya & Jáuegui, José María & 1920 \\
\hline \multirow[t]{2}{*}{ Hidalgo, Juan } & Celos aun del aire matan & Calderón, Pedro & 1660 \\
\hline & La púrpura de la rosa & Calderón, Pedro & 1660 \\
\hline Inzenga, José & El campamento & & 1851 \\
\hline
\end{tabular}




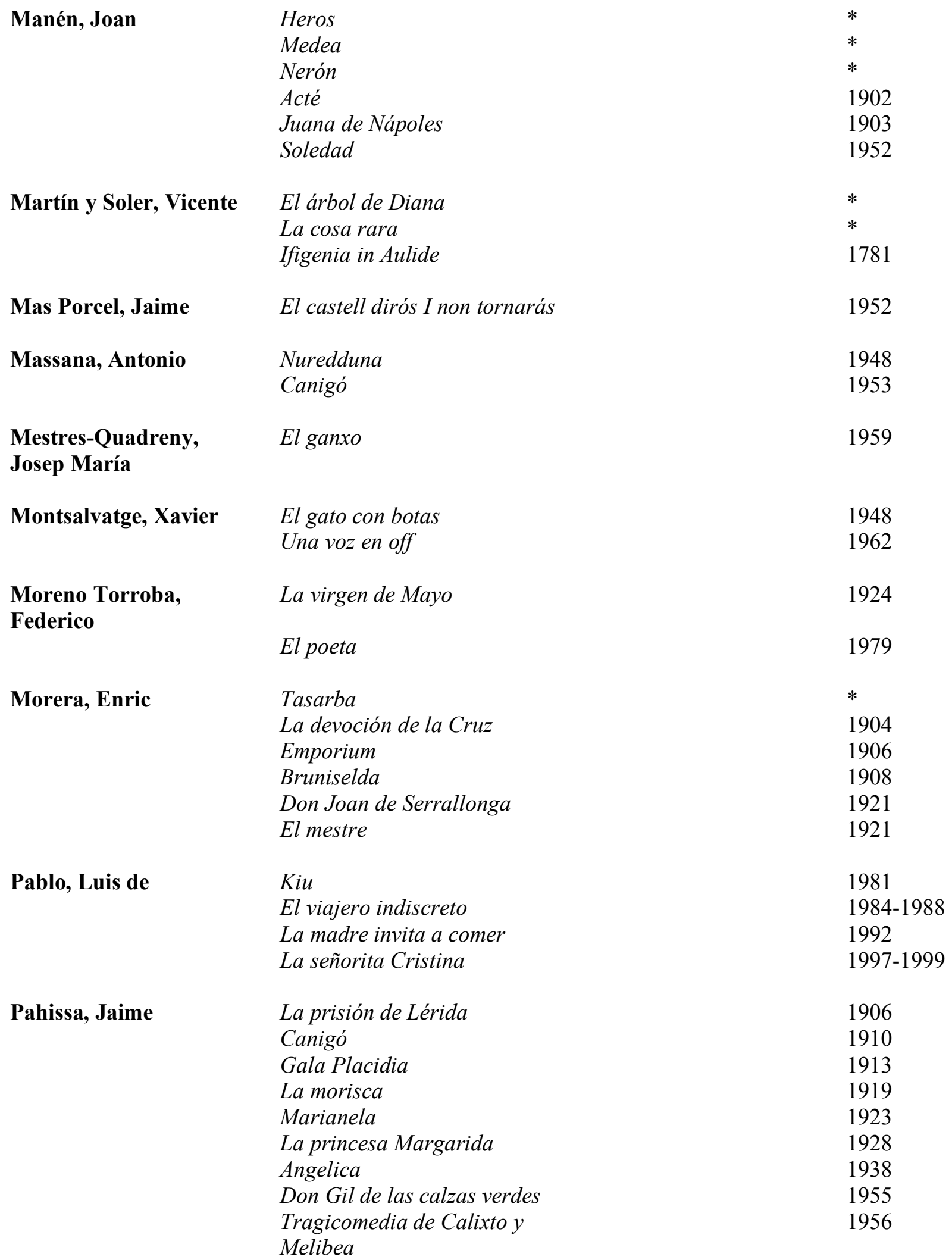




\begin{tabular}{|c|c|c|c|}
\hline Pedrell, Felipe & La Celestina & & 1904 \\
\hline Piccinini, Filippo & La selva sin amor & Vega, Lope de & 1629 \\
\hline \multirow[t]{5}{*}{ Rodrigo, María } & Becqueriana & Quintero brothers & $*$ \\
\hline & Canción de amor & & $*$ \\
\hline & Diana cazadora & & $*$ \\
\hline & La flor de la vida & & $*$ \\
\hline & La romería del Rocío & & $*$ \\
\hline \multirow[t]{2}{*}{ Salvador, Matilde } & La filla del rey barbut & & 1943 \\
\hline & Vinatea & & 1973 \\
\hline \multirow[t]{2}{*}{ Soler, Josep } & Agammenon & & 1960 \\
\hline & Edipo y Yocasta & & 1972 \\
\hline Suriñach, Carlos & $\begin{array}{l}\text { El mozo que casó con mujer } \\
\text { brava }\end{array}$ & & 1948 \\
\hline Terradellas, Domènec & Sesostri & & 1774 \\
\hline Toldrá, Eduard & El giravolt de maig & & 1928 \\
\hline \multirow[t]{2}{*}{ Turina, Joaquín } & La sulamita & & 1897 \\
\hline & Jardin de oriente & & 1922 \\
\hline Usandizaga, José María & Mendi-Mendiyan & & 1910 \\
\hline Villa, Ricardo & Raimundo Lulio & & 1902 \\
\hline \multirow[t]{4}{*}{ Viña, Facundo de la } & Almas muertas & & $*$ \\
\hline & La espigadora & & $*$ \\
\hline & La montaraza de Grandes & & $*$ \\
\hline & La princesa flor de roble & & $*$ \\
\hline \multirow[t]{2}{*}{ Vives, Amadeo } & Artús & & 1897 \\
\hline & Eda d'Uriach & & 1900 \\
\hline
\end{tabular}

\footnotetext{
* The date of composition was not found for this opera.
} 


\section{Appendix C: Mexico: Operas in Chronological Order}

\section{Year}

\begin{tabular}{|c|c|}
\hline 1711 & La parténope \\
\hline 1821 & México libre \\
\hline 1859 & Catalina di Guisa \\
\hline 1859 & Una riña de aguadores \\
\hline 1863 & Romeo y Julieta \\
\hline 1863 & Peitro d'Avano \\
\hline 1863 & Clotilde de Conzenza \\
\hline 1864 & Pirro de Aragón \\
\hline 1864 & Agorante Rey de Nubia \\
\hline 1866 & Ildegonda \\
\hline 1871 & Guatimotzín \\
\hline 1871 & Don Quijote en la venta encantada \\
\hline 1877 & Gino Corsini \\
\hline 1892 & Colón en Santo Domingo \\
\hline 1900 & Atzimba \\
\hline 1901 & El rey poeta \\
\hline 1902 & Zulema \\
\hline 1903 & Ossiam \\
\hline ca.1903 & Anita \\
\hline 1906 & La leyenda de Rudel \\
\hline 1909 & Matilde (México en 1810) \\
\hline 1910 & Nicolás Bravo \\
\hline 1915 & Tonantzin \\
\hline 1915 & Due amori \\
\hline 1916 & Los mineros \\
\hline 1917 & Monna Vanna \\
\hline 1918 & Anáhuac \\
\hline ca. 1920 & Cíhuatl \\
\hline 1920 & Morgana \\
\hline 1921 & Xiulitl \\
\hline 1922 & Citlali \\
\hline 1923 & Cíhuatl \\
\hline 1923 & Nezahualcóyotl \\
\hline 1923 & El mandarín \\
\hline 1924 & Kinchi \\
\hline 1924 & Xtabai \\
\hline
\end{tabular}

Composer

Zumaya, Manuel de

Bustamante, José María

Paniagua y Vázquez,

Cenobio

Paniagua y Vázquez,

Cenobio

Morales, Melesio

Paniagua y Vázquez,

Cenobio

Valle, Octaviano

Canales, Leonardo

Meneses, Miguel

Morales, Melesio

Ortega del Villar, Aniceto

Planas, Miguel

Morales, Melesio

Morales, Julio M.

Castro Herrera, Ricardo

Campa, Gustavo E.

Elorduy Medina, Ernesto

Carrillo, Julián

Morales, Melesio

Castro Herrera, Ricardo

Carrillo, Julián

Tello, Rafael J.

Alonso, Julia

Tello, Rafael J.

Vásquez, José F.

Vásquez, José F.

Miramontes, Arnulfo

Miramontes, Arnulfo

Juevas, Alejandro

Carrillo, Julián

Vásquez, José F.

Castillo, Fernando del

Samaniego, Carlos

Vásquez, José F.

Río Escalante, Gustavo

Río Escalante, Gustavo
Michel, Alberto

Michel, Alberto

Campos, Rubén M.

Golisciani, Enrico

Michel, Alberto

Mariscal, Ignacio

Trucco, Eduardo

Molina Enríquez,

Andrés

Maeterlinck, Maurice

Bracho, Francisco

Bermejo, Manuel M.

Erzell, Catalina d'

Bermejo, Manuel M. 


\begin{tabular}{|c|c|c|c|}
\hline 1925 & La mestiza & Castillo, Fernando del & $\begin{array}{l}\text { Castillo, Fernando } \\
\text { del }\end{array}$ \\
\hline 1926 & El rajah & Vásquez, José F. & \\
\hline 1928 & Ya yaax can & $\begin{array}{l}\text { Cárdenas Samada, } \\
\text { Cornelio }\end{array}$ & $\begin{array}{l}\text { Cárdenas Samada, } \\
\text { Cornelio }\end{array}$ \\
\hline 1928 & El último sueño & Vásquez, José F. & Bermejo, Manuel M. \\
\hline ca. 1930 & Querétaro & Amaya, Alberto & Frías, Heriberto \\
\hline 1939 & Tzentzontli & Pérez Cámara, Efraín & \\
\hline 1941 & Tata Vasco & Bernal Jiménez, Miguel & Muñoz, Manuel \\
\hline 1948 & Elena & $\begin{array}{l}\text { Hernández Moncada, } \\
\text { Eduardo }\end{array}$ & Zendejas, Francisco \\
\hline 1948 & La mulata de Córdoba & $\begin{array}{l}\text { Moncayo Garcîa, José } \\
\text { Pablo }\end{array}$ & $\begin{array}{l}\text { Villarrutia, Xavier, } \\
\text { and Lazo, Agustín }\end{array}$ \\
\hline 1948 & Carlota & Sandi Meneses, Luis & Zendejas, Francisco \\
\hline 1949 & Nezahualcóyotl & Téllez Oropeza, Roberto & \\
\hline 1950 & Tumulum Veneris & Muench, Gerhart & \\
\hline $1960-1961$ & Vasco Núñez de Balboa & Vásquez, José F. & \\
\hline 1961 & Severino & $\begin{array}{l}\text { Moreno Manzano, } \\
\text { Salvador }\end{array}$ & Carballido, Emilio \\
\hline 1962 & Misa de seis & Jiménez Mabarak, Carlos & \\
\hline 1964 & La señora en su balcón & Sandi Meneses, Luis & \\
\hline 1968 & $\begin{array}{l}\text { The Visitors (Pánfilo y Lauretta and } \\
\text { El amor propiciado) }\end{array}$ & Chávez, Carlos & Kallman, Chester \\
\hline 1972 & La mascherata & Adomián, Lan & \\
\hline 1973 & Romance de doña Balada & Urreta Arroyo, Alicia & \\
\hline 1975 & La gracia & Téllez Oropeza, Roberto & \\
\hline 1976 & Ifigenia cruel & Téllez Oropeza, Roberto & \\
\hline 1978 & La mujer y su sombra & Alcázar, Miguel & \\
\hline 1978 & Jaque & Stern, Mario & \\
\hline 1978 & Acapulco & Téllez Oropeza, Roberto & \\
\hline 1979 & Encuentro en el ocaso & Catán, Daniel & Montemayor, Carlos \\
\hline 1980 & Leoncio y Lena & Ibarra, Federico & $\begin{array}{l}\text { Enríquez, José } \\
\text { Ramón }\end{array}$ \\
\hline 1980 & Big Klaus and Little Klaus & Stern, Mario & \\
\hline 1981 & Orestes parte & Ibarra, Federico & $\begin{array}{l}\text { Enríquez, José } \\
\text { Ramón }\end{array}$ \\
\hline 1982 & La Güera Rodríguez & Jiménez Mabarak, Carlos & Alejandro, Julio \\
\hline 1983 & Pinocchio & Stern, Mario & \\
\hline 1984 & $\begin{array}{l}\text { El monje (Ambrosio o la fábula del } \\
\text { mal amor) }\end{array}$ & Guzmán, José Antonio & $\begin{array}{l}\text { Guzmán, José } \\
\text { Antonio }\end{array}$ \\
\hline 1985 & El cuarto rey mago & Olvera, Rafael & \\
\hline 1985 & Popol Vuh & Pazos, Carlos & \\
\hline 1985 & El espejo encantado & Urreta Arroyo, Alicia & \\
\hline 1986 & Madre Juana & Ibarra, Federico & $\begin{array}{l}\text { Enríquez, José } \\
\text { Ramón }\end{array}$ \\
\hline 1988 & El pequeño principe & Ibarra, Federico & Tavira, Luis de \\
\hline 1988 & Aura & Lavista, Mario & Tovar, Juan \\
\hline 1989 & La hija de Rapaccini & Catán, Daniel & \\
\hline 1989 & Alicia & Ibarra, Federico & $\begin{array}{l}\text { Enríquez, José } \\
\text { Ramón }\end{array}$ \\
\hline 1990 & La encrucijada & Enríquez, Manuel & \\
\hline
\end{tabular}


1990

1991

1991

1991

1992

1992

1993

1993

1994

1994

1995

1997

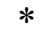

$*$

$*$

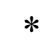

*

*

*

*

*

*

$*$

*

*

$*$

*
La sunamita

Pedro Páramo

La séptima semilla

Anacleto Morones

Ifigenia cruel

Dos mundos

Mambo

Llamadas de Oriente

Florencia en el Amazonas

Despertar al sueño

En tiempo del ave

La tentación de San Antonio

Giovanni di Castiglia

Leonor

Chichén Itzá

Escena Itzalanas

Don Juan de Austria

Reinaldo y Elina o la sacerdote

peruana

Keofar

La virgen de San Juan

Cuauhtémoc

El Rey Domingo I

Olga de Monterrojo

Edith

Atala

El hada del lago

Judith

Luisa de Lavalliere

Anita y Lilia o secretos de un padre

El conde de Ucanor

El juicio final

González de Avila

Un amor de Hernán Cortés

Asuero (incomplete)

Carlomagno

Cleopatra

La tempestad

$L a$ vendetta

El patria

Felipe IV

El patio florido

I Due Foscari y Fidelio

Adelaida y Comingo
Rodríguez, Marcela

Estrada, Julio

Paredes, Hilda

Rasgado, Víctor

Espinosa, Leandro

Tamez, Gerardo

Álvarez, Javier

Cataño, Fernando

Catán, Daniel

Ibarra, Federico

Berlioz, Sergio

Cortez, Luis Jaime

Baca, Luis

Baca, Luis

Cárdenas Samada,

Cornelio

Cárdenas Samada,

Cornelio

Castro Herrera, Ricardo

Covarrubias, Manuel

Felipe Villanueva

Gómezanda, Antonio

González Peña, Fernando

María y Campos, Antonio

de

María y Campos, Antonio

de

Mejía, Estanislao

Meneses, Miguel

Meneses, Miguel

Meneses, Miguel

Meneses, Miguel

Moguel, Ricalde

Moguel, Ricalde

Moguel, Ricalde

Moguel, Ricalde

Moguel, Ricalde

Morales, Melesio

Morales, Melesio

Morales, Melesio

Morales, Melesio

Palacios, Rafael

Paniagua y Vázquez,

Cenobio

Planas, Miguel

Ponce, Manuel M.

Torres Serrato, Mateo

Vega, Ramón
Whiteson, Karen

Fuentes-Berain, Marcel

Cortez, Luis Jaime

Solera, Tamístocles

Bozzeti, Carlo

Cárdenas Samada, Cornelio

Cárdenas Samada, Cornelio 
* $\quad$ El grito de dolores

* $\quad$ La Reina de León
Vega, Ramón

Vega, Ramón
Mateos, Juan A.

* The date of composition was not found for this opera. 


\section{Appendix D: \\ Mexico: Operas and Composers}

\section{Composer}

Title

Librettist

Year

Adomián, Lan

La mascherata

1972

Alcázar, Miguel

La mujer y su sombra

1978

Alonso, Julia

Tonantzin

1915

Álvarez, Javier

Mambo

Amaya, Alberto

Querétaro

Giovanni di Castiglia

Leonor

En tiempo del ave

Tata Vasco

Pirro de Aragón

Chichén Itzá

Escena Itzalanas

Ya yaax can

Ossiam

Matilde (México en 1810)

Xiulitl

Xiulitl

Cíhuatl

La mestiza

Don Juan de Austria

Atzimba

La leyenda de Rudel
Muñoz, Manuel

Ortega, Francisco Luis

Michel, Alberto

1901

Frías, Heriberto

Solera, Tamístocles

Bozzeti, Carlo

1993

ca. 1930

$*$

$*$

1995

1941

1821

1864

Cárdenas Samada,

Cornelio

Cárdenas Samada,

Cornelio

Cárdenas Samada,

Cornelio

1928

1903

1909

1921

1921

Erzell, Catalina d'

1923

Castillo, Fernando del

1925

Michel, Alberto

1900

Michel, Alberto 


\begin{tabular}{|c|c|c|c|}
\hline Catán, Daniel & $\begin{array}{l}\text { Encuentro en el ocaso } \\
\text { La hija de Rapaccini } \\
\text { Florencia en el Amazonas }\end{array}$ & $\begin{array}{l}\text { Montemayor, Carlos } \\
\text { Fuentes-Berain, Marcel }\end{array}$ & $\begin{array}{l}1979 \\
1989 \\
1994\end{array}$ \\
\hline Cataño, Fernando & Llamadas de Oriente & & 1993 \\
\hline Chávez, Carlos & $\begin{array}{l}\text { The Visitors (Pánfilo y } \\
\text { Lauretta and El amor } \\
\text { propiciado) }\end{array}$ & Kallman, Chester & 1968 \\
\hline Cortez, Luis Jaime & La tentación de San Antonio & Cortez, Luis Jaime & 1997 \\
\hline Covarrubias, Manuel & $\begin{array}{l}\text { Reinaldo y Elina o la } \\
\text { sacerdote peruana }\end{array}$ & & * \\
\hline Elorduy Medina, Ernesto & Zulema & Campos, Rubén M. & 1902 \\
\hline Enríquez, Manuel & La encrucijada & & 1990 \\
\hline Espinosa, Leandro & Ifigenia cruel & & 1992 \\
\hline Estrada, Julio & Pedro Páramo & & 1991 \\
\hline Felipe Villanueva & Keofar & & $*$ \\
\hline Gómezanda, Antonio & La virgen de San Juan & & $*$ \\
\hline González Peña, Fernando & Cuauhtémoc & & $*$ \\
\hline Guzmán, José Antonio & $\begin{array}{l}\text { El monje (Ambrosio o la } \\
\text { fábula del mal amor) }\end{array}$ & Guzmán, José Antonio & 1984 \\
\hline $\begin{array}{l}\text { Hernández Moncada, } \\
\text { Eduardo }\end{array}$ & Elena & Zendejas, Francisco & 1948 \\
\hline Ibarra, Federico & $\begin{array}{l}\text { Leoncio y Lena } \\
\text { Orestes parte } \\
\text { Madre Juana } \\
\text { El pequeño principe } \\
\text { Alicia } \\
\text { Despertar al sueño }\end{array}$ & $\begin{array}{l}\text { Enríquez, José Ramón } \\
\text { Enríquez, José Ramón } \\
\text { Enríquez, José Ramón } \\
\text { Tavira, Luis de } \\
\text { Enríquez, José Ramón }\end{array}$ & $\begin{array}{l}1980 \\
1981 \\
1986 \\
1988 \\
1989 \\
1994\end{array}$ \\
\hline Jiménez Mabarak, Carlos & $\begin{array}{l}\text { Misa de seis } \\
\text { La Güera Rodríguez }\end{array}$ & Alejandro, Julio & $\begin{array}{l}1962 \\
1982\end{array}$ \\
\hline Juevas, Alejandro & Morgana & & 1920 \\
\hline Lavista, Mario & Aura & Tovar, Juan & 1988 \\
\hline
\end{tabular}




\begin{tabular}{|c|c|c|c|}
\hline \multirow{2}{*}{$\begin{array}{l}\text { María y Campos, Antonio } \\
\text { de }\end{array}$} & \multicolumn{2}{|l|}{ El Rey Domingo I } & \multirow{2}{*}{$*$} \\
\hline & Olga de Monterrojo & & \\
\hline Mejía, Estanislao & Edith & & $*$ \\
\hline \multirow[t]{5}{*}{ Meneses, Miguel } & Atala & & $*$ \\
\hline & El hada del lago & & $*$ \\
\hline & Judith & & $*$ \\
\hline & Luisa de Lavalliere & & $*$ \\
\hline & Agorante Rey de Nubia & & 1864 \\
\hline Miramontes, Arnulfo & $\begin{array}{l}\text { Anáhuac } \\
\text { Cíhuatl }\end{array}$ & Bracho, Francisco & $\begin{array}{l}1918 \\
\text { ca. } 1920\end{array}$ \\
\hline \multirow[t]{5}{*}{ Moguel, Ricalde } & $\begin{array}{l}\text { Anita y Lilia o secretos de un } \\
\text { padre }\end{array}$ & & $*$ \\
\hline & El conde de Ucanor & & $*$ \\
\hline & El juicio final & & $*$ \\
\hline & González de Avila & & $*$ \\
\hline & Un amor de Hernán Cortés & & $*$ \\
\hline $\begin{array}{l}\text { Moncayo Garcîa, José } \\
\text { Pablo }\end{array}$ & La mulata de Córdoba & $\begin{array}{l}\text { Villarrutia, Xavier, and } \\
\text { Lazo, Agustín }\end{array}$ & 1948 \\
\hline Morales, Julio M. & Colón en Santo Domingo & & 1892 \\
\hline \multirow[t]{8}{*}{ Morales, Melesio } & Asuero (incomplete) & & $*$ \\
\hline & Carlomagno & & $*$ \\
\hline & Cleopatra & & $*$ \\
\hline & La tempestad & & $*$ \\
\hline & Romeo y Julieta & & 1863 \\
\hline & Ildegonda & & 1866 \\
\hline & Gino Corsini & & 1877 \\
\hline & Anita & Golisciani, Enrico & ca. 1903 \\
\hline Moreno Manzano, Salvador & Severino & Carballido, Emilio & 1961 \\
\hline Muench, Gerhart & Tumulum Veneris & & 1950 \\
\hline Olvera, Rafael & El cuarto rey mago & & 1985 \\
\hline Ortega del Villar, Aniceto & Guatimotzín & & 1871 \\
\hline Palacios, Rafael & La vendetta & & $*$ \\
\hline \multirow{2}{*}{$\begin{array}{l}\text { Paniagua y Vázquez, } \\
\text { Cenobio }\end{array}$} & El patria & & $*$ \\
\hline & $\begin{array}{l}\text { Catalina di Guisa } \\
\text { Una riña de aguadores } \\
\text { Peitro d'Avano }\end{array}$ & Romani, Félix & $\begin{array}{l}1859 \\
1859 \\
1863\end{array}$ \\
\hline
\end{tabular}




\begin{tabular}{|c|c|c|c|}
\hline Paredes, Hilda & La séptima semilla & Whiteson, Karen & 1991 \\
\hline Pazos, Carlos & Popol Vuh & & 1985 \\
\hline Pérez Cámara, Efraín & Tzentzontli & & 1939 \\
\hline Planas, Miguel & $\begin{array}{l}\text { Felipe IV } \\
\text { Don Quijote en la venta } \\
\text { encantada }\end{array}$ & & * 1871 \\
\hline Ponce, Manuel M. & El patio florido & & $*$ \\
\hline Rasgado, Víctor & Anacleto Morones & & 1991 \\
\hline Río Escalante, Gustavo & $\begin{array}{l}\text { Kinchi } \\
\text { Xtabai }\end{array}$ & & $\begin{array}{l}1924 \\
1924\end{array}$ \\
\hline Rodríguez, Marcela & La sunamita & & 1990 \\
\hline Samaniego, Carlos & Nezahualcóyotl & & 1923 \\
\hline Sandi Meneses, Luis & $\begin{array}{l}\text { Carlota } \\
\text { La señora en su balcón }\end{array}$ & Zendejas, Francisco & $\begin{array}{l}1948 \\
1964\end{array}$ \\
\hline Stern, Mario & $\begin{array}{l}\text { Jaque } \\
\text { Big Klaus and Little Klaus } \\
\text { Pinocchio }\end{array}$ & & $\begin{array}{l}1978 \\
1980 \\
1983\end{array}$ \\
\hline Tamez, Gerardo & Dos mundos & & 1992 \\
\hline Téllez Oropeza, Roberto & $\begin{array}{l}\text { Nezahualcóyotl } \\
\text { La gracia } \\
\text { Ifigenia cruel } \\
\text { Acapulco }\end{array}$ & & $\begin{array}{l}1949 \\
1975 \\
1976 \\
1978\end{array}$ \\
\hline Tello, Rafael J. & $\begin{array}{l}\text { Nicolás Bravo } \\
\text { Due amori }\end{array}$ & $\begin{array}{l}\text { Mariscal, Ignacio } \\
\text { Trucco, Eduardo }\end{array}$ & $\begin{array}{l}1910 \\
1915\end{array}$ \\
\hline Torres Serrato, Mateo & I Due Foscari y Fidelio & & $*$ \\
\hline Urreta Arroyo, Alicia & $\begin{array}{l}\text { Romance de doña Balada } \\
\text { El espejo encantado }\end{array}$ & & $\begin{array}{l}1973 \\
1985\end{array}$ \\
\hline Valle, Octaviano & Clotilde de Conzenza & & 1863 \\
\hline
\end{tabular}


Vásquez, José F.

Vega, Ramón

Zumaya, Manuel de
Los mineros

Monna Vanna

Citlali

El mandarín

El rajah

El último sueño

Vasco Núñez de Balboa

Adelaida y Comingo

El grito de dolores

La Reina de León

La parténope
Molina Enríquez,

Andrés

Maeterlinck, Maurice

Bermejo, Manuel M.

Bermejo, Manuel M.

Bermejo, Manuel M.

1960 -

Mateos, Juan A.

Stempiglia, Silvio
1928

1961

1916

1917

1922

1923

1926

$*$

$*$

$*$

1711

* The date of composition was not found for this opera. 


\section{Appendix E: \\ South America: Operas in Chronological Order}

\begin{tabular}{|c|c|c|c|c|}
\hline Year & Title & Composer & Librettist & Country \\
\hline 1678 & $\begin{array}{l}\text { El robo de Proserpina y } \\
\text { sentencia de Júpiter }\end{array}$ & Coppola, Filippo & & Peru \\
\hline 1701 & La púrpura de la rosa & $\begin{array}{l}\text { Torrejon y Velasco, } \\
\text { Tomás de }\end{array}$ & Calderón, Pedro & Peru \\
\hline 1708 & El major escudo de Perseo & Ceruti, Roque & $\begin{array}{l}\text { Oms y de Santa Pau, } \\
\text { Manuel de }\end{array}$ & Peru \\
\hline 1711 & Triunfos de amor y poder & $\begin{array}{l}\text { Peralta Barnuevo, } \\
\text { Pedro }\end{array}$ & & Peru \\
\hline $\begin{array}{l}1717- \\
1727\end{array}$ & San Ignacio de Loyola & Zipoli, Domenico & & Paraguay \\
\hline $\begin{array}{l}1720- \\
1730\end{array}$ & San Francisco Xavier & $\begin{array}{l}\text { Unknown indigenous } \\
\text { composer }\end{array}$ & & Paraguay \\
\hline 1846 & Telésfora & Ried, Aquina & & Chile \\
\hline 1873 & Virginia & Montero, José Ángel & & Venezuela \\
\hline 1874 & Ester & $\begin{array}{l}\text { Ponce de León, José } \\
\text { María }\end{array}$ & $\begin{array}{l}\text { Pombo, Rafael, and } \\
\text { Briceño, Manuel }\end{array}$ & Colombia \\
\hline 1875 & La gatta bianca & $\begin{array}{l}\text { Hargreaves, Francisco } \\
\text { A. }\end{array}$ & & Argentina \\
\hline 1876 & El vampiro & $\begin{array}{l}\text { Hargreaves, Francisco } \\
\text { A. }\end{array}$ & & Argentina \\
\hline 1877 & Atahualpa & Pasta, Carlo Enrique & & Peru \\
\hline 1878 & La Parisina & Giribaldi, Tomás & Felice Romani & Uruguay \\
\hline 1880 & Florinda & $\begin{array}{l}\text { Ponce de León, José } \\
\text { María }\end{array}$ & Pombo, Rafael & Colombia \\
\hline 1882 & Manfredi di Svevia & Giribaldi, Tomás & Ducati, José Emilio & Uruguay \\
\hline 1883 & Gualterio & $\begin{array}{l}\text { Torrens Boqué, } \\
\text { Eduardo }\end{array}$ & $\begin{array}{l}\text { Torrens Boqué, } \\
\text { Eduardo }\end{array}$ & Argentina \\
\hline 1890 & Esmeralda & $\begin{array}{l}\text { García Lalanne, } \\
\text { Eduardo }\end{array}$ & $\begin{array}{l}\text { García Lalanne, } \\
\text { Eduardo }\end{array}$ & Argentina \\
\hline 1892 & El León de Venecia & $\begin{array}{l}\text { Agnillo, Corradino d', } \\
\text { and Verardini, Enea }\end{array}$ & Tulio, Atilio di & Argentina \\
\hline 1893 & Evangelina & Berutti, Arturo & Cortella, Alejandro & Argentina \\
\hline 1893 & Clara & Grazioso Panizza, Juan & $\begin{array}{l}\text { Grazioso Panizza, } \\
\text { Juan }\end{array}$ & Argentina \\
\hline 1895 & Taras Bulba & Berutti, Arturo & Godio, Guillermo & Argentina \\
\hline 1897 & Pampa & Berutti, Arturo & Borra, Guido & Argentina \\
\hline 1897 & Cecilia & Grazioso Panizza, Juan & & Argentina \\
\hline 1897 & Los estudiantes de Bolonia & $\begin{array}{l}\text { Hargreaves, Francisco } \\
\text { A. }\end{array}$ & Menchaca, Angel & Argentina \\
\hline 1897 & Il Fidanzato del mare & Panizza, Héctor & Carugati, Romeo & Argentina \\
\hline 1899 & Yupanki & Berutti, Arturo & $\begin{array}{l}\text { Rodríguez Larreta, } \\
\text { Enrique }\end{array}$ & Argentina \\
\hline
\end{tabular}




\begin{tabular}{|c|c|}
\hline 1900 & Juan de Garay \\
\hline 1900 & Atahualpa \\
\hline 1900 & Medioevo Latino \\
\hline 1900 & El segreto \\
\hline 1900 & Ollanta (two \\
\hline $\begin{array}{l}\text { and } \\
1920\end{array}$ & versions/revised) \\
\hline 1902 & Khrysé \\
\hline 1905 & Ivan \\
\hline 1907 & Shafras \\
\hline 1908 & Horrida Nox \\
\hline 1908 & Aurora \\
\hline 1909 & Zoraida \\
\hline 1910 & Blanca de Beaulieu \\
\hline 1914 & Sueño de alma \\
\hline 1915 & Blancaflor \\
\hline 1916 & Huemac \\
\hline 1917 & La angelical Manuelita \\
\hline 1917 & Ardid de amor \\
\hline 1918 & Tucumán \\
\hline 1919 & Los heroes \\
\hline 1919 & Petronio \\
\hline 1919 & Tupá \\
\hline 1920 & Ariana y Dionysos \\
\hline 1920 & Amy Robsart \\
\hline 1920 & Saika \\
\hline 1922 & El evadido (L'Evaso) \\
\hline 1922 & Flor de nieve \\
\hline 1922 & $\begin{array}{l}\text { La sirocchia (Litigio de } \\
\text { amor -renamed 1932) }\end{array}$ \\
\hline 1923 & Raquela \\
\hline 1923 & Ilse \\
\hline 1923 & La guitarra \\
\hline 1924 & Les noces d'or \\
\hline 1924 & Nazdah \\
\hline 1925 & Tabaré \\
\hline 1926 & Corimayo \\
\hline 1926 & Ollantay \\
\hline 1927 & Frenos \\
\hline 1927 & Afrodita \\
\hline 1927 & Chrysanthème \\
\hline 1929 & La Magdalena \\
\hline
\end{tabular}

Bonicioli, Ricardo
Cattelani, Ferruccio
Panizza, Héctor
Torrens Boqué,
Eduardo
Valle Riesga, José
María

Berutti, Arturo

García Mansilla,

Eduardo

Gaito, Constantino

Berutti, Arturo

Panizza, Héctor

Bautista Massa, Juan

Stiattesi, César A.

López Buchardo,

Carlos

Schiuma, Alfredo Luis

Rogatis, Pascual de

García Mansilla,

Eduardo

Pedrell, Carlos

Boero, Felipe

Berutti, Arturo

Gaito, Constantino

Maurage, Auguste

Boero, Felipe

Schiuma, Alfredo Luis

Ugarte, Floro M.

Bautista Massa, Juan

Gaito, Constantino

Schiuma, Alfredo Luis

Boero, Felipe

Gilardi, Gilardo

Pedrell, Carlos

Maurage, Auguste

Palma, Athos

Schiuma, Alfredo Luis

Casella, Enrique Mario

Gaito, Constantino

Espoile, Raúl H.

Luzzatti, Arturo

Peacan del Sar, Rafael

Bautista Massa, Juan
Ricardo Bonicioli

Cattelani, Ferruccio

Illica, Luigi

Torrens Boqué,

Eduardo

Blume, Federico, and Peru

Fernán Cisneros, Luis

Berutti, Arturo, and Argentina

Louys, Pierre

García Mansilla, Argentina

Eduardo

Scubla, Ferruccio Argentina

Berutti, Arturo Argentina

Quesada, Héctor, and Argentina

Illica, Luigi

Cei, Ivo

Argentina

Romanelli, Humberto Argentina

Díaz, Leopoldo Argentina

Magno, Agenor Argentina

Montagne, Edmundo Argentina

García Mansilla, Argentina

Eduardo

Klingsor, Tristán Uruguay

Díaz, Leopoldo Argentina

Campana, $\mathrm{H}$. Argentina

Romanelli, Humberto Argentina

Montagne, Edmundo Argentina

Díaz, Leopoldo Argentina

Magno, Agenor Argentina

Ugarte, Floro M. Argentina

Giglio, Elio de Argentina

Colelli, G.

Magno, Agenor

Argentina

Argentina

Díaz, Leopoldo Argentina

Giergi Contri, Cosme Argentina

Courville, Xavier Uruguay

Crabbé, Armand Argentina

San Leo, Gino de Argentina

Servetti Reeves, Argentina

Jorge

Pascarella, Luis Uruguay

Mercante, Victor Argentina

Mercante, Victor Argentina

Puget, Théophile, and Argentina

Bernard, Gabreil

Colelli, G.

Argentina

Trucchi, Ernesto

Argentina 


\begin{tabular}{|c|c|c|c|c|}
\hline 1929 & El matrero & Boero, Felipe & Rodríguez, Yamandú & Argentina \\
\hline 1929 & Lázaro & Gaito, Constantino & Mercante, Víctor & Argentina \\
\hline 1932 & La sangre de las guitarras & Gaito, Constantino & $\begin{array}{l}\text { Reta, Vicente G., and } \\
\text { Viale, Carlos Max }\end{array}$ & Argentina \\
\hline 1932 & La leyenda del urutaú & Gilardi, Gilardo & Oliva Nogueira, José & Argentina \\
\hline 1933 & Beatrice & Angelis, Arturo de & Testena, Folco & Argentina \\
\hline 1934 & La tapera & Casella, Enrique Mario & $\begin{array}{l}\text { Casella, Enrique } \\
\text { Mario }\end{array}$ & Uruguay \\
\hline 1935 & La novia del Hereje & Rogatis, Pascual de & $\begin{array}{l}\text { Allende Iragorri, } \\
\text { Tomás }\end{array}$ & Argentina \\
\hline 1937 & Siripo & Boero, Felipe & Bayon Herrera, Luis & Argentina \\
\hline 1937 & La ciudad roja & Espoile, Raúl H. & $\begin{array}{l}\text { Schaeffer Gallo, } \\
\text { Carlos }\end{array}$ & Argentina \\
\hline 1939 & Chasca & Casella, Enrique Mario & $\begin{array}{l}\text { Casella, Enrique } \\
\text { Mario }\end{array}$ & Uruguay \\
\hline 1939 & Bizancio & Panizza, Héctor & Macchi, Gustavo & Argentina \\
\hline 1939 & Las virgenes del sol & Schiuma, Alfredo Luis & Herrera, Ataliva & Argentina \\
\hline 1940 & Gualicho & Pinto, Alfredo & $\begin{array}{l}\text { Beltrán Núñez, } \\
\text { Rosario }\end{array}$ & Argentina \\
\hline 1941 & Lin-calel & Espósito, Arnaldo d' & Mercante, Victor & Argentina \\
\hline 1943 & La Zapatera prodigiosa & Castro, Juan José & $\begin{array}{l}\text { García Lorca, } \\
\text { Federico }\end{array}$ & Argentina \\
\hline 1946 & Pablo y Virginia & $\begin{array}{l}\text { Curubeto Godoy, María } \\
\text { Isabel }\end{array}$ & $\begin{array}{l}\text { Adami, Giuseppe, } \\
\text { and Simone, Renato }\end{array}$ & Argentina \\
\hline 1949 & La zapatera prodigiosa & Castro, Juan José & $\begin{array}{l}\text { García Lorca, } \\
\text { Federico }\end{array}$ & Argentina \\
\hline 1951 & La cuarterona & $\begin{array}{l}\text { García Estrada, Juan } \\
\text { Agustín }\end{array}$ & $\begin{array}{l}\text { García Estrada, Juan } \\
\text { Agustín }\end{array}$ & Argentina \\
\hline 1952 & Proserpina y el extranjero & Castro, Juan José & Carlo, Omar del & Argentina \\
\hline 1953 & Bodas de sangre & Castro, Juan José & $\begin{array}{l}\text { García Lorca, } \\
\text { Federico }\end{array}$ & Argentina \\
\hline 1953 & El oro del Inca & Iglesias Villoud, Héctor & $\begin{array}{l}\text { Iglesias Villoud, } \\
\text { Héctor }\end{array}$ & Argentina \\
\hline 1954 & Zincali & Boero, Felipe & Capdevila, Arturo & Argentina \\
\hline 1954 & La otra voz & Castro, José María & Obieta, Jorge de & Argentina \\
\hline 1956 & Bodas de sangre & Castro, Juan José & $\begin{array}{l}\text { García Lorca, } \\
\text { Federico }\end{array}$ & Argentina \\
\hline 1957 & Flor de Durazno & Madina, Francisco de & Cucullo, Carlos & Argentina \\
\hline 1957 & Marianita Limeña & Sciammarella, Valdo & Javier, Francisco & Argentina \\
\hline 1959 & La pendiente & Camps, Pompeyo & Camps, Pompeyo & Argentina \\
\hline $\begin{array}{l}1963- \\
1964\end{array}$ & Don Rodrigo & Ginastera, Alberto & Casona, Alejandro & Argentina \\
\hline 1965 & Prometeo 45 & Arizaga, Rodolfo & Arizaga, Rodolfo & Argentina \\
\hline 1966 & Escorial & Tauriello, Antonio & & Argentina \\
\hline 1967 & Bomarzo & Ginastera, Alberto & $\begin{array}{l}\text { Mujica Láinez, } \\
\text { Manuel }\end{array}$ & Argentina \\
\hline 1968 & Pedido de mano & Ficher, Jacobo & Chejov, Anton & Argentina \\
\hline 1969 & La voz del silencio & Perusso, Mario & $\begin{array}{l}\text { Barrera Oro, } \\
\text { Leonidas }\end{array}$ & Argentina \\
\hline 1971 & Beatrix Cenci & Ginastera, Alberto & $\begin{array}{l}\text { Shand, William, and } \\
\text { Girri, Alberto }\end{array}$ & Argentina \\
\hline
\end{tabular}


1971

1973

1975

1977

1978 La pasión de Buster Keaton

1980 Jettatore

1986 Edipo en San Telmo

1987 La hacienda

1988 La segunda vida

1989 Alicia en el país de las maravillas

1989 El milagro secreto

1989 Escorial

1989 Adonias

1990 Maratón

1990 iOh, eternidad...!

1990 La venganza de Carmen

1991 La venganza de don Mendo

1991 Antigona Velez

1992 La casa sin sosiego

1993 Guayaquil

1994 Minotauro

1995 La oscuridad de la razón

1995 La ciudad ausente

1996 Saverio el cruel

$\begin{array}{ll}* & \text { Evangelina } \\ * & \text { Facunda } \\ * & \text { Vendetta } \\ * & \text { Cochabamba } \\ * & \text { Atacama } \\ * & \text { Diana } \\ * & \text { Idona } \\ * & \text { Il grenatiere } \\ * & \text { Ismenilda } \\ * & \text { Ondega } \\ * & \text { Walhalla } \\ * & \text { Atahualpa (first act) }\end{array}$

Tauriello, Antonio

Drei, Claudio Guidi

Zorzi, Juan Carlos

García Morillo,

Roberto

Gandini, Gerardo

Rattenbach, Augusto

Benjamín

Rattenbach, Augusto

Benjamín

Camps, Pompeyo

López de la Rosa,

Horacio

Lambertini, Marta

Matalón, Martín

Perusso, Mario

Pinto, Alejandro

Camps, Pompeyo

Lambertini, Marta

Wilenski, Osías

Mastronardi, Ernesto

Zorzi, Juan Carlos

Gandini, Gerardo

Perusso, Mario

Rattenbach, Augusto

Benjamín

Camps, Pompeyo

Gandini, Gerardo

González Casellas,

Fernando

Berutti, Arturo

Berutti, Arturo

Berutti, Arturo

Berutti, Pablo María

Ried, Aquina

Ried, Aquina

Ried, Aquina

Ried, Aquina

Ried, Aquina

Ried, Aquina

Ried, Aquina

Valle Riesga, José

María
Drei, Claudio Guidi

Collazo, Javier

García Morillo,

Roberto

Rattenbach, Augusto

Benjamín

García de la Mata, Argentina Elena

Camps, Pompeyo

López de la Rosa, Horacio

Perusso, Mario

Pinto, Alejandro

Monti, Ricardo

Wilenski, Osías

Mastronardi, Ernesto

Collazo, Javier

Gambaro, Griselda

Pérez Pardellas,

Agustín

Girolami, Argentino

Monti, Ricardo

Piglia, Ricardo

González Casellas,

Fernando
Argentina

Argentina

Argentina

Argentina

Argentina

Argentina

Argentina

Argentina

Argentina

Argentina

Argentina

Argentina

Argentina

Argentina

Argentina

Argentina

Argentina

Argentina

Argentina

Argentina

Argentina

Argentina

Argentina

Argentina

Argentina

Argentina

Argentina

Chile

Chile

Chile

Chile

Chile

Chile

Chile

Peru

\footnotetext{
* The date of composition was not found for this opera.
} 


\section{Appendix F: \\ South America: Operas and Composers}

Composer

Agnillo, Corradino d', El León de Venecia and Verardini, Enea

\begin{tabular}{|c|c|}
\hline Angelis, Arturo de & Beatrice \\
\hline Arizaga, Rodolfo & Prometeo 45 \\
\hline Bautista Massa, Juan & $\begin{array}{l}\text { Zoraida } \\
\text { El evadido (L'Evaso) } \\
\text { La Magdalena }\end{array}$ \\
\hline \multirow[t]{3}{*}{ Berutti, Arturo } & $\begin{array}{l}\text { Evangelina } \\
\text { Facunda } \\
\text { Vendetta } \\
\text { Evangelina } \\
\text { Taras Bulba } \\
\text { Pampa } \\
\text { Yupanki }\end{array}$ \\
\hline & Khrysé \\
\hline & $\begin{array}{l}\text { Horrida Nox } \\
\text { Los heroes }\end{array}$ \\
\hline Berutti, Pablo María & Cochabamba \\
\hline Boero, Felipe & $\begin{array}{l}\text { Tucumán } \\
\text { Ariana y Dionysos } \\
\text { Raquela } \\
\text { El matrero } \\
\text { Siripo } \\
\text { Zincali }\end{array}$ \\
\hline
\end{tabular}

Bonicioli, Ricardo

Camps, Pompeyo

Title

ecia

Juan de Garay

La pendiente

La hacienda

Maratón

La oscuridad de la razón

\section{Librettist}

Tulio, Atilio di

Testena, Folco

Arizaga, Rodolfo

Cei, Ivo

Giglio, Elio de

Trucchi, Ernesto

Cortella, Alejandro

Godio, Guillermo

Borra, Guido

Rodríguez Larreta,

Enrique

Berutti, Arturo, and

Louys, Pierre

Berutti, Arturo

Campana, $\mathrm{H}$.

Díaz, Leopoldo

Díaz, Leopoldo

Díaz, Leopoldo

Rodríguez, Yamandú

Bayon Herrera, Luis

Capdevila, Arturo

Ricardo Bonicioli

Camps, Pompeyo

Camps, Pompeyo

Monti, Ricardo

Monti, Ricardo
Year Country

1892 Argentina

1933 Argentina

1965 Argentina

1909 Argentina

1922 Argentina

1929 Argentina

* Argentina

* Argentina

* Argentina

1893 Argentina

1895 Argentina

1897 Argentina

1899 Argentina

1902 Argentina

1908 Argentina

1919 Argentina

* $\quad$ Argentina

1918 Argentina

1920 Argentina

1923 Argentina

1929 Argentina

1937 Argentina

1954 Argentina

1900 Argentina

1959 Argentina

1987 Argentina

1990 Argentina

1995 Argentina 


\begin{tabular}{|c|c|c|c|c|}
\hline Casella, Enrique & Corimayo & Pascarella, Luis & 1926 & Uruguay \\
\hline & La tapera & Casella, Enrique & 1934 & Uruguay \\
\hline & Chasca & $\begin{array}{l}\text { Casella, Enrique } \\
\text { Mario }\end{array}$ & 1939 & Uruguay \\
\hline Castro, José María & La otra voz & Obieta, Jorge de & 1954 & Argentina \\
\hline Castro, Juan José & La Zapatera prodigiosa & $\begin{array}{l}\text { García Lorca, } \\
\text { Federico }\end{array}$ & 1943 & Argentina \\
\hline & La zapatera prodigiosa & $\begin{array}{l}\text { García Lorca, } \\
\text { Federico }\end{array}$ & 1949 & Argentina \\
\hline & Proserpina y el extranjero & Carlo, Omar del & 1952 & Argentina \\
\hline & Bodas de sangre & $\begin{array}{l}\text { García Lorca, } \\
\text { Federico }\end{array}$ & 1953 & Argentina \\
\hline & Bodas de sangre & $\begin{array}{l}\text { García Lorca, } \\
\text { Federico }\end{array}$ & 1956 & Argentina \\
\hline Cattelani, Ferruccio & Atahualpa & Cattelani, Ferruccio & 1900 & Argentina \\
\hline Ceruti, Roque & El major escudo de Perseo & $\begin{array}{l}\text { Oms y de Santa Pau, } \\
\text { Manuel de }\end{array}$ & 1708 & Peru \\
\hline Coppola, Filippo & $\begin{array}{l}\text { El robo de Proserpina y } \\
\text { sentencia de Júpiter }\end{array}$ & & 1678 & Peru \\
\hline $\begin{array}{l}\text { Curubeto Godoy, } \\
\text { María Isabel }\end{array}$ & Pablo y Virginia & $\begin{array}{l}\text { Adami, Giuseppe, } \\
\text { and Simone, Renato }\end{array}$ & 1946 & Argentina \\
\hline Drei, Claudio Guidi & Medea & Drei, Claudio Guidi & 1973 & Argentina \\
\hline Espoile, Raúl H. & Frenos & Mercante, Victor & 1927 & Argentina \\
\hline & La ciudad roja & $\begin{array}{l}\text { Schaeffer Gallo, } \\
\text { Carlos }\end{array}$ & 1937 & Argentina \\
\hline Espósito, Arnaldo d' & Lin-calel & Mercante, Victor & 1941 & Argentina \\
\hline Ficher, Jacobo & Pedido de mano & Chejov, Anton & 1968 & Argentina \\
\hline Gaito, Constantino & Shafras & Scubla, Ferruccio & 1907 & Argentina \\
\hline & Petronio & Romanelli, Humberto & 1919 & Argentina \\
\hline & Flor de nieve & Colelli, G. & 1922 & Argentina \\
\hline & Ollantay & Mercante, Victor & 1926 & Argentina \\
\hline & Lázaro & Mercante, Víctor & 1929 & Argentina \\
\hline & La sangre de las guitarras & $\begin{array}{l}\text { Reta, Vicente G., and } \\
\text { Viale, Carlos Max }\end{array}$ & 1932 & Argentina \\
\hline Gandini, Gerardo & La pasión de Buster Keaton & & 1978 & Argentina \\
\hline & La casa sin sosiego & Gambaro, Griselda & 1992 & Argentina \\
\hline & La ciudad ausente & Piglia, Ricardo & 1995 & Argentina \\
\hline
\end{tabular}


García Estrada, Juan La cuarterona
Agustín

\begin{tabular}{|c|c|}
\hline $\begin{array}{l}\text { García Lalanne, } \\
\text { Eduardo }\end{array}$ & Esmeralda \\
\hline García Mansilla, & Ivan \\
\hline & La angelical Manuel \\
\hline $\begin{array}{l}\text { García Morillo, } \\
\text { Roberto }\end{array}$ & El caso maillard \\
\hline Gilardi, Gilardo & $\begin{array}{l}\text { Ilse } \\
\text { La leyenda del uruta }\end{array}$ \\
\hline Ginastera, Alberto & Don Rodrigo \\
\hline & Bomarzo \\
\hline & Beatrix Cenci \\
\hline Giribaldi, Tomás & $\begin{array}{l}\text { La Parisina } \\
\text { Manfredi di Svevia }\end{array}$ \\
\hline $\begin{array}{l}\text { González Casellas, } \\
\text { Fernando }\end{array}$ & Saverio el cruel \\
\hline $\begin{array}{l}\text { Grazioso Panizza, } \\
\text { Juan }\end{array}$ & $\begin{array}{l}\text { Clara } \\
\text { Cecilia }\end{array}$ \\
\hline
\end{tabular}

Hargreaves, Francisco La gatta bianca A.

Iglesias Villoud, $\quad$ El oro del Inca
Héctor
Lambertini, Marta Alicia en el país de las maravillas

¡Oh, eternidad...!

López Buchardo, Sueño de alma Carlos

López de la Rosa, La segunda vida Horacio
García Estrada, Juan 1951 Argentina Agustín

García Lalanne, $\quad 1890 \quad$ Argentina

Eduardo

García Mansilla, 1905 Argentina

Eduardo

García Mansilla, 1917 Argentina

Eduardo

García Morillo, 1977 Argentina

Roberto

Giergi Contri, Cosme 1923 Argentina

Oliva Nogueira, José 1932 Argentina

Casona, Alejandro 1963- Argentina 1964

Mujica Láinez, $\quad 1967$ Argentina

Manuel

Shand, William, and 1971 Argentina

Girri, Alberto

Felice Romani $\quad 1878$ Uruguay

Ducati, José Emilio 1882 Uruguay

González Casellas, 1996 Argentina Fernando

Grazioso Panizza, 1893 Argentina Juan

1897 Argentina

1875 Argentina

1876 Argentina

Menchaca, Angel 1897 Argentina

Iglesias Villoud, $1953 \quad$ Argentina Héctor

1989 Argentina

1990 Argentina

Díaz, Leopoldo $1914 \quad$ Argentina

López de la Rosa, 1988 Argentina Horacio 


\begin{tabular}{|c|c|c|c|c|}
\hline Luzzatti, Arturo & Afrodita & $\begin{array}{l}\text { Puget, Théophile, and } \\
\text { Bernard, Gabreil }\end{array}$ & 1927 & Argentina \\
\hline Madina, Francisco de & Flor de Durazno & Cucullo, Carlos & 1957 & Argentina \\
\hline Mastronardi, Ernesto & La venganza de don Mendo & Mastronardi, Ernesto & 1991 & Argentina \\
\hline Matalón, Martín & El milagro secreto & & 1989 & Argentina \\
\hline Maurage, Auguste & $\begin{array}{l}\text { Tupá } \\
\text { Les noces d'or }\end{array}$ & $\begin{array}{l}\text { Montagne, Edmundo } \\
\text { Crabbé, Armand }\end{array}$ & $\begin{array}{l}1919 \\
1924\end{array}$ & $\begin{array}{l}\text { Argentina } \\
\text { Argentina }\end{array}$ \\
\hline Montero, José Ángel & Virginia & & 1873 & Venezuela \\
\hline Palma, Athos & Nazdah & San Leo, Gino de & 1924 & Argentina \\
\hline Panizza, Héctor & $\begin{array}{l}\text { Il Fidanzato del mare } \\
\text { Medioevo Latino } \\
\text { Aurora }\end{array}$ & $\begin{array}{l}\text { Carugati, Romeo } \\
\text { Illica, Luigi } \\
\text { Quesada, Héctor, and } \\
\text { Illica, Luigi }\end{array}$ & $\begin{array}{l}1897 \\
1900 \\
1908\end{array}$ & $\begin{array}{l}\text { Argentina } \\
\text { Argentina } \\
\text { Argentina }\end{array}$ \\
\hline Pasta, Carlo Enrique & Atahualpa & & 1877 & Peru \\
\hline Peacan del Sar, Rafael & Chrysanthème & Colelli, G. & 1927 & Argentina \\
\hline Pedrell, Carlos & $\begin{array}{l}\text { Ardid de amor } \\
\text { La guitarra }\end{array}$ & $\begin{array}{l}\text { Klingsor, Tristán } \\
\text { Courville, Xavier }\end{array}$ & $\begin{array}{l}1917 \\
1923\end{array}$ & $\begin{array}{l}\text { Uruguay } \\
\text { Uruguay }\end{array}$ \\
\hline $\begin{array}{l}\text { Peralta Barnuevo, } \\
\text { Pedro }\end{array}$ & Triunfos de amor y poder & & 1711 & Peru \\
\hline \multirow[t]{3}{*}{ Perusso, Mario } & La voz del silencio & $\begin{array}{l}\text { Barrera Oro, } \\
\text { Leonidas }\end{array}$ & 1969 & Argentina \\
\hline & Escorial & Perusso, Mario & 1989 & Argentina \\
\hline & Guayaquil & $\begin{array}{l}\text { Pérez Pardellas, } \\
\text { Agustín }\end{array}$ & 1993 & Argentina \\
\hline Pinto, Alejandro & Adonias & Pinto, Alejandro & 1989 & Argentina \\
\hline Pinto, Alfredo & Gualicho & $\begin{array}{l}\text { Beltrán Núñez, } \\
\text { Rosario }\end{array}$ & 1940 & Argentina \\
\hline \multirow[t]{2}{*}{$\begin{array}{l}\text { Ponce de León, José } \\
\text { María }\end{array}$} & Ester & $\begin{array}{l}\text { Pombo, Rafael, and } \\
\text { Briceño, Manuel }\end{array}$ & 1874 & Colombia \\
\hline & Florinda & Pombo, Rafael & 1880 & Colombia \\
\hline
\end{tabular}


Rattenbach, Augusto Benjamín

$\begin{array}{ll} & \text { Edipo en San } \\ & \text { Minotauro } \\ & \\ \text { Ried, Aquinama } & \text { Diana } \\ & \text { Idona } \\ \text { Il grenatiere } \\ \text { Ismenilda } \\ \text { Ondega } \\ \text { Walhalla } \\ \text { Telésfora }\end{array}$

Rogatis, Pascual de

Huemac

La novia del Hereje

Blancaflor

Amy Robsart

La sirocchia (Litigio de amor-renamed 1932)

Tabaré

Las virgenes del sol

Sciammarella, Valdo Marianita Limeña

Stiattesi, César A. Blanca de Beaulieu

Tauriello, Antonio

Torrejon y Velasco, Tomás de

Torrens Boqué, Eduardo

$\begin{array}{ll} & \text { El segreto } \\ \text { Ugarte, Floro M. } & \text { Saika } \\ \begin{array}{l}\text { Valle Riesga, José } \\ \text { María }\end{array} & \text { Atahualpa (first act) } \\ & \begin{array}{l}\text { Ollanta (two } \\ \text { versions/revised) }\end{array}\end{array}$

Escorial
Rattenbach, Augusto $1980 \quad$ Argentina Benjamín

García de la Mata, 1986 Argentina Elena

Girolami, Argentino 1994 Argentina

* Chile

* Chile

* Chile

* Chile

* Chile

* Chile

* Chile

1846 Chile

Montagne, Edmundo 1916 Argentina

Allende Iragorri, 1935 Argentina

Tomás

Magno, Agenor 1915 Argentina

Magno, Agenor $\quad 1920 \quad$ Argentina

Magno, Agenor 1922 Argentina

Servetti Reeves, 1925 Argentina

Jorge

Herrera, Ataliva 1939 Argentina

Javier, Francisco 1957 Argentina

Romanelli, Humberto 1910 Argentina

Les guerres picrocholines

1966 Argentina

1971 Argentina

Calderón, Pedro

1701 Peru

Torrens Boqué, 1883 Argentina

Eduardo

Torrens Boqué, $\quad 1900 \quad$ Argentina

Eduardo

Ugarte, Floro M. 1920 Argentina

* Peru

Blume, Federico, and $1900 \quad$ Peru

Fernán Cisneros, Luis and

1920 


$\begin{array}{lllll}\text { Wilenski, Osías } & \text { La venganza de Carmen } & \text { Wilenski, Osías } & 1990 & \text { Argentina } \\ \text { Zipoli, Domenico } & \text { San Ignacio de Loyola } & & 1717- & \text { Paraguay } \\ & & & 1727 & \\ \text { Zorzi, Juan Carlos } & \begin{array}{l}\text { El timbre } \\ \text { Antigona Velez }\end{array} & \begin{array}{l}\text { Collazo, Javier } \\ \text { Collazo, Javier }\end{array} & 1975 & \text { Argentina } \\ & & & 1991 & \text { Argentina } \\ \begin{array}{l}\text { Unknown indigenous } \\ \text { composer }\end{array} & \text { San Francisco Xavier } & & 1720- & \text { Paraguay } \\ & & 1730 & \end{array}$

* The date of composition was not found for this opera. 


\section{Appendix G: \\ South America: Operas by Country}

\begin{tabular}{|c|c|c|c|c|}
\hline Country & Year & Title & Composer & Librettist \\
\hline \multirow[t]{32}{*}{ Argentina } & 1875 & La gatta bianca & Hargreaves, Francisco A. & \\
\hline & 1876 & El vampiro & Hargreaves, Francisco A. & \\
\hline & 1883 & Gualterio & Torrens Boqué, Eduardo & $\begin{array}{l}\text { Torrens Boqué, } \\
\text { Eduardo }\end{array}$ \\
\hline & 1890 & Esmeralda & García Lalanne, Eduardo & $\begin{array}{l}\text { García Lalanne, } \\
\text { Eduardo }\end{array}$ \\
\hline & 1892 & El León de Venecia & $\begin{array}{l}\text { Agnillo, Corradino d', } \\
\text { and Verardini, Enea }\end{array}$ & Tulio, Atilio di \\
\hline & 1893 & Evangelina & Berutti, Arturo & Cortella, Alejandro \\
\hline & 1893 & Clara & Grazioso Panizza, Juan & $\begin{array}{l}\text { Grazioso Panizza, } \\
\text { Juan }\end{array}$ \\
\hline & 1895 & Taras Bulba & Berutti, Arturo & Godio, Guillermo \\
\hline & 1897 & Pampa & Berutti, Arturo & Borra, Guido \\
\hline & 1897 & Cecilia & Grazioso Panizza, Juan & \\
\hline & 1897 & Los estudiantes de Bolonia & Hargreaves, Francisco A. & Menchaca, Angel \\
\hline & 1897 & Il Fidanzato del mare & Panizza, Héctor & Carugati, Romeo \\
\hline & 1899 & Yupanki & Berutti, Arturo & $\begin{array}{l}\text { Rodríguez Larreta, } \\
\text { Enrique }\end{array}$ \\
\hline & 1900 & Juan de Garay & Bonicioli, Ricardo & Ricardo Bonicioli \\
\hline & 1900 & Atahualpa & Cattelani, Ferruccio & Cattelani, Ferruccio \\
\hline & 1900 & Medioevo Latino & Panizza, Héctor & Illica, Luigi \\
\hline & 1900 & El segreto & Torrens Boqué, Eduardo & $\begin{array}{l}\text { Torrens Boqué, } \\
\text { Eduardo }\end{array}$ \\
\hline & 1902 & Khrysé & Berutti, Arturo & $\begin{array}{l}\text { Berutti, Arturo, and } \\
\text { Louys, Pierre }\end{array}$ \\
\hline & 1905 & Ivan & García Mansilla, Eduardo & $\begin{array}{l}\text { García Mansilla, } \\
\text { Eduardo }\end{array}$ \\
\hline & 1907 & Shafras & Gaito, Constantino & Scubla, Ferruccio \\
\hline & 1908 & Horrida Nox & Berutti, Arturo & Berutti, Arturo \\
\hline & 1908 & Aurora & Panizza, Héctor & $\begin{array}{l}\text { Quesada, Héctor, and } \\
\text { Illica, Luigi }\end{array}$ \\
\hline & 1909 & Zoraida & Bautista Massa, Juan & Cei, Ivo \\
\hline & 1910 & Blanca de Beaulieu & Stiattesi, César A. & Romanelli, Humberto \\
\hline & 1914 & Sueño de alma & López Buchardo, Carlos & Díaz, Leopoldo \\
\hline & 1915 & Blancaflor & Schiuma, Alfredo Luis & Magno, Agenor \\
\hline & 1916 & Ниетас & Rogatis, Pascual de & Montagne, Edmundo \\
\hline & 1917 & La angelical Manuelita & García Mansilla, Eduardo & $\begin{array}{l}\text { García Mansilla, } \\
\text { Eduardo }\end{array}$ \\
\hline & 1918 & Tucumán & Boero, Felipe & Díaz, Leopoldo \\
\hline & 1919 & Los heroes & Berutti, Arturo & Campana, H. \\
\hline & 1919 & Petronio & Gaito, Constantino & Romanelli, Humberto \\
\hline & 1919 & Tupá & Maurage, Auguste & Montagne, Edmundo \\
\hline
\end{tabular}




\begin{tabular}{|c|c|c|c|}
\hline 1920 & Ariana y Dionysos & Boero, Felipe & Díaz, Leopoldo \\
\hline 1920 & Amy Robsart & Schiuma, Alfredo Luis & Magno, Agenor \\
\hline 1920 & Saika & Ugarte, Floro M. & Ugarte, Floro M. \\
\hline 1922 & El evadido (L'Evaso) & Bautista Massa, Juan & Giglio, Elio de \\
\hline 1922 & Flor de nieve & Gaito, Constantino & Colelli, G. \\
\hline 1922 & $\begin{array}{l}\text { La sirocchia (Litigio de } \\
\text { amor-renamed 1932) }\end{array}$ & Schiuma, Alfredo Luis & Magno, Agenor \\
\hline 1923 & Raquela & Boero, Felipe & Díaz, Leopoldo \\
\hline 1923 & Ilse & Gilardi, Gilardo & Giergi Contri, Cosme \\
\hline 1924 & Les noces d'or & Maurage, Auguste & Crabbé, Armand \\
\hline 1924 & Nazdah & Palma, Athos & San Leo, Gino de \\
\hline 1925 & Tabaré & Schiuma, Alfredo Luis & $\begin{array}{l}\text { Servetti Reeves, } \\
\text { Jorge }\end{array}$ \\
\hline 1926 & Ollantay & Gaito, Constantino & Mercante, Victor \\
\hline 1927 & Frenos & Espoile, Raúl H. & Mercante, Victor \\
\hline 1927 & Afrodita & Luzzatti, Arturo & $\begin{array}{l}\text { Puget, Théophile, and } \\
\text { Bernard, Gabreil }\end{array}$ \\
\hline 1927 & Chrysanthème & Peacan del Sar, Rafael & Colelli, G. \\
\hline 1929 & La Magdalena & Bautista Massa, Juan & Trucchi, Ernesto \\
\hline 1929 & El matrero & Boero, Felipe & Rodríguez, Yamandú \\
\hline 1929 & Lázaro & Gaito, Constantino & Mercante, Víctor \\
\hline 1932 & La sangre de las guitarras & Gaito, Constantino & $\begin{array}{l}\text { Reta, Vicente G., and } \\
\text { Viale, Carlos Max }\end{array}$ \\
\hline 1932 & La leyenda del urutaú & Gilardi, Gilardo & Oliva Nogueira, José \\
\hline 1933 & Beatrice & Angelis, Arturo de & Testena, Folco \\
\hline 1935 & La novia del Hereje & Rogatis, Pascual de & $\begin{array}{l}\text { Allende Iragorri, } \\
\text { Tomás }\end{array}$ \\
\hline 1937 & Siripo & Boero, Felipe & Bayon Herrera, Luis \\
\hline 1937 & La ciudad roja & Espoile, Raúl H. & $\begin{array}{l}\text { Schaeffer Gallo, } \\
\text { Carlos }\end{array}$ \\
\hline 1939 & Bizancio & Panizza, Héctor & Macchi, Gustavo \\
\hline 1939 & Las virgenes del sol & Schiuma, Alfredo Luis & Herrera, Ataliva \\
\hline 1940 & Gualicho & Pinto, Alfredo & $\begin{array}{l}\text { Beltrán Núñez, } \\
\text { Rosario }\end{array}$ \\
\hline 1941 & Lin-calel & Espósito, Arnaldo d' & Mercante, Victor \\
\hline 1943 & La Zapatera prodigiosa & Castro, Juan José & $\begin{array}{l}\text { García Lorca, } \\
\text { Federico }\end{array}$ \\
\hline 1946 & Pablo y Virginia & $\begin{array}{l}\text { Curubeto Godoy, María } \\
\text { Isabel }\end{array}$ & $\begin{array}{l}\text { Adami, Giuseppe, } \\
\text { and Simone, Renato }\end{array}$ \\
\hline 1949 & La zapatera prodigiosa & Castro, Juan José & $\begin{array}{l}\text { García Lorca, } \\
\text { Federico }\end{array}$ \\
\hline 1951 & La cuarterona & $\begin{array}{l}\text { García Estrada, Juan } \\
\text { Agustín }\end{array}$ & $\begin{array}{l}\text { García Estrada, Juan } \\
\text { Agustín }\end{array}$ \\
\hline 1952 & Proserpina y el extranjero & Castro, Juan José & Carlo, Omar del \\
\hline 1953 & Bodas de sangre & Castro, Juan José & $\begin{array}{l}\text { García Lorca, } \\
\text { Federico }\end{array}$ \\
\hline 1953 & El oro del Inca & Iglesias Villoud, Héctor & $\begin{array}{l}\text { Iglesias Villoud, } \\
\text { Héctor }\end{array}$ \\
\hline 1954 & Zincali & Boero, Felipe & Capdevila, Arturo \\
\hline
\end{tabular}




\begin{tabular}{|c|c|c|c|}
\hline 1954 & La otra voz & Castro, José María & Obieta, Jorge de \\
\hline 1956 & Bodas de sangre & Castro, Juan José & $\begin{array}{l}\text { García Lorca, } \\
\text { Federico }\end{array}$ \\
\hline 1957 & Flor de Durazno & Madina, Francisco de & Cucullo, Carlos \\
\hline 1957 & Marianita Limeña & Sciammarella, Valdo & Javier, Francisco \\
\hline 1959 & La pendiente & Camps, Pompeyo & Camps, Pompeyo \\
\hline $\begin{array}{l}1963- \\
1964\end{array}$ & Don Rodrigo & Ginastera, Alberto & Casona, Alejandro \\
\hline 1965 & Prometeo 45 & Arizaga, Rodolfo & Arizaga, Rodolfo \\
\hline 1966 & Escorial & Tauriello, Antonio & \\
\hline 1967 & Bomarzo & Ginastera, Alberto & $\begin{array}{l}\text { Mujica Láinez, } \\
\text { Manuel }\end{array}$ \\
\hline 1968 & Pedido de mano & Ficher, Jacobo & Chejov, Anton \\
\hline 1969 & La voz del silencio & Perusso, Mario & $\begin{array}{l}\text { Barrera Oro, } \\
\text { Leonidas }\end{array}$ \\
\hline 1971 & Beatrix Cenci & Ginastera, Alberto & $\begin{array}{l}\text { Shand, William, and } \\
\text { Girri, Alberto }\end{array}$ \\
\hline 1971 & Les guerres picrocholines & Tauriello, Antonio & \\
\hline 1973 & Medea & Drei, Claudio Guidi & Drei, Claudio Guidi \\
\hline 1975 & El timbre & Zorzi, Juan Carlos & Collazo, Javier \\
\hline 1977 & El caso maillard & García Morillo, Roberto & $\begin{array}{l}\text { García Morillo, } \\
\text { Roberto }\end{array}$ \\
\hline 1978 & $\begin{array}{l}\text { La pasión de Buster } \\
\text { Keaton }\end{array}$ & Gandini, Gerardo & \\
\hline 1980 & Jettatore & $\begin{array}{l}\text { Rattenbach, Augusto } \\
\text { Benjamín }\end{array}$ & $\begin{array}{l}\text { Rattenbach, Augusto } \\
\text { Benjamín }\end{array}$ \\
\hline 1986 & Edipo en San Telmo & $\begin{array}{l}\text { Rattenbach, Augusto } \\
\text { Benjamín }\end{array}$ & $\begin{array}{l}\text { García de la Mata, } \\
\text { Elena }\end{array}$ \\
\hline 1987 & La hacienda & Camps, Pompeyo & Camps, Pompeyo \\
\hline 1988 & La segunda vida & $\begin{array}{l}\text { López de la Rosa, } \\
\text { Horacio }\end{array}$ & $\begin{array}{l}\text { López de la Rosa, } \\
\text { Horacio }\end{array}$ \\
\hline 1989 & $\begin{array}{l}\text { Alicia en el país de las } \\
\text { maravillas }\end{array}$ & Lambertini, Marta & \\
\hline 1989 & El milagro secreto & Matalón, Martín & \\
\hline 1989 & Escorial & Perusso, Mario & Perusso, Mario \\
\hline 1989 & Adonias & Pinto, Alejandro & Pinto, Alejandro \\
\hline 1990 & Maratón & Camps, Pompeyo & Monti, Ricardo \\
\hline 1990 & ¡Oh, eternidad...! & Lambertini, Marta & \\
\hline 1990 & La venganza de Carmen & Wilenski, Osías & Wilenski, Osías \\
\hline 1991 & $\begin{array}{l}\text { La venganza de don } \\
\text { Mendo }\end{array}$ & Mastronardi, Ernesto & Mastronardi, Ernesto \\
\hline 1991 & Antigona Velez & Zorzi, Juan Carlos & Collazo, Javier \\
\hline 1992 & La casa sin sosiego & Gandini, Gerardo & Gambaro, Griselda \\
\hline 1993 & Guayaquil & Perusso, Mario & $\begin{array}{l}\text { Pérez Pardellas, } \\
\text { Agustín }\end{array}$ \\
\hline 1994 & Minotauro & $\begin{array}{l}\text { Rattenbach, Augusto } \\
\text { Benjamín }\end{array}$ & Girolami, Argentino \\
\hline 1995 & La oscuridad de la razón & Camps, Pompeyo & Monti, Ricardo \\
\hline 1995 & La ciudad ausente & Gandini, Gerardo & Piglia, Ricardo \\
\hline
\end{tabular}


1996 Saverio el cruel

* Cochabamba

* Evangelina

* Facunda

* Vendetta

$\begin{array}{cll}\text { Chile } & 1846 & \text { Telésfora } \\ * & \text { Atacama } \\ * & \text { Diana } \\ * & \text { Idona } \\ * & \text { Il grenatiere } \\ * & \text { Ismenilda } \\ * & \text { Ondega } \\ * & \text { Walhalla }\end{array}$

Colombia $1874 \quad$ Ester

$1880 \quad$ Florinda

$\begin{array}{lll}\text { Paraguay } & 1717- & \text { San Ignacio de Loyola } \\ & 1727 & \\ 1720- & \text { San Francisco Xavier } \\ & 1730 & \end{array}$

\begin{tabular}{|c|c|c|}
\hline \multirow[t]{8}{*}{ Peru } & 1678 & $\begin{array}{l}\text { El robo de Proserpina y } \\
\text { sentencia de Júpiter }\end{array}$ \\
\hline & & \\
\hline & 1708 & El major escudo de Perseo \\
\hline & 1711 & Triunfos de amor y poder \\
\hline & 1877 & Atahualpa \\
\hline & 1900 & Ollanta (two \\
\hline & $\begin{array}{l}\text { and } \\
1920\end{array}$ & versions/revised) \\
\hline & $*$ & Atahualpa (first act) \\
\hline
\end{tabular}

$\begin{array}{ccl}\text { Uruguay } & 1878 & \text { La Parisina } \\ & 1882 & \text { Manfredi di Svevia } \\ 1917 & \text { Ardid de amor } \\ 1923 & \text { La guitarra } \\ 1926 & \text { Corimayo } \\ 1934 & \text { La tapera } \\ & \\ 1939 & \text { Chasca }\end{array}$

González Casellas, Fernando Berutti, Pablo María Berutti, Arturo Berutti, Arturo

Berutti, Arturo

Ried, Aquina

Ried, Aquina

Ried, Aquina

Ried, Aquina

Ried, Aquina

Ried, Aquina

Ried, Aquina

Ried, Aquina

Ponce de León, José María

Ponce de León, José

María

Zipoli, Domenico

Unknown indigenous composer

Coppola, Filippo

Torrejon y Velasco,

Tomás de

Ceruti, Roque

Peralta Barnuevo, Pedro

Pasta, Carlo Enrique

Valle Riesga, José María

Valle Riesga, José María

Giribaldi, Tomás

Giribaldi, Tomás

Pedrell, Carlos

Pedrell, Carlos

Casella, Enrique Mario

Casella, Enrique Mario

Casella, Enrique Mario
González Casellas, Fernando

Pombo, Rafael, and Briceño, Manuel Pombo, Rafael

Calderón, Pedro

Oms y de Santa Pau, Manuel de

Blume, Federico, and Fernán Cisneros, Luis

Felice Romani Ducati, José Emilio Klingsor, Tristán Courville, Xavier Pascarella, Luis Casella, Enrique Mario Casella, Enrique Mario 
Venezuela $1873 \quad$ Virginia

Montero, José Ángel

* The date of composition was not found for this opera. 


\section{Appendix H: \\ Central America and the Caribbean: Operas in Chronological Order}

Year

Title

$\begin{array}{ll}1867 & \begin{array}{l}\text { Angelo, tirano de Padua } \\ 1871\end{array} \\ & \begin{array}{l}\text { Las primeras armas de } \\ \text { Richelieu }\end{array} \\ 1875 & \text { La hija de Jefté (Seila) } \\ 1877 & \text { Zilia } \\ 1880 & \text { La czarina } \\ 1884- & \text { Cristóforo Colombo } \\ 1886 & \\ 1885 & \text { Baltazar } \\ 1887- & \text { Lucifer } \\ 1889 & \\ 1898 & \text { Yumurí }\end{array}$

1901 El náufrago

1911 La Dolorosa

1918 Doreya

1919- Quiché Vináte

1924

1921

1936

*

$*$

* Con Papaner o la burla del hipnotismo

* El diablo contrabandista

* María de Cuéllar
Composer

Villate, Gaspar

Villate, Gaspar

Fuentes Matons, Laureano

Villate, Gaspar

Villate, Gaspar

Villate, Gaspar

Villate, Gaspar

Villate, Gaspar

Sánchez de Fuentes,

Eduardo

Sánchez de Fuentes,

Eduardo

Sánchez de Fuentes,

Eduardo

Sánchez de Fuentes,

Eduardo

Castillo, Jesús

Mauri Esteve, José

Castillo, Jesús

Claudio, Pablo

Gutiérrez, Felipe

Martínez Corres, Cristóbal

Martínez Corres, Cristóbal

Claudio, Pablo

\section{Librettist}

Country

Cuba

Cuba

Cuba

Cuba

Cuba

Cuba

Cuba

Cuba

Fernández de Castro, Cuba

Rafael

Cuba

Uhrbach, Federico Cuba

Cabrisas, Hilarión Cuba

Guatemala

Juliá, Tomás

Cuba

Guatemala

Dominican

Republic

Puerto

Rico

Cuba

Cuba

Dominican

Republic

\footnotetext{
* The date of composition was not found for this opera.
} 


\section{Appendix I: \\ Central America and the Caribbean: Operas and Composers}

\section{Composer}

Castillo, Jesús

Claudio, Pablo

Laureano

Gutiérrez, Felipe

Martínez Corres, Cristóbal

$\begin{array}{ll}\text { Mauri Esteve, José } & \text { La esclava } \\ \begin{array}{l}\text { Sánchez de Fuentes, } \\ \text { Eduardo }\end{array} & \text { Yumuri } \\ & \text { El náufrago } \\ & \text { La Dolorosa } \\ & \text { Doreya } \\ & \\ \text { Villate, Gaspar } & \text { Las primeras armas de } \\ & \text { Richelieu } \\ & \text { Zilia } \\ & \text { La czarina } \\ & \text { Cristóforo Colombo } \\ \text { Baltazar } \\ \text { Lucifer }\end{array}$

\section{Librettist}

Quiché Vináte

Nicté

América

María de Cuéllar

La hija de Jefté (Seila)

Amor de un pescador

Con Papaner o la burla del hipnotismo

El diablo contrabandista

Juliá, Tomás

Fernández de Castro, Rafael

Uhrbach, Federico

Cabrisas, Hilarión
Year Country

1919-1924 Guatemala

1936 Guatemala

* Dominican

Republic

Dominican

Republic

$1875 \quad$ Cuba

Puerto

Rico

* $\quad$ Cuba

* Cuba

$1921 \quad$ Cuba

$1898 \quad$ Cuba

$1901 \quad$ Cuba

1911 Cuba

1918 Cuba

$1867 \quad$ Cuba

1871 Cuba

1877 Cuba

$1880 \quad$ Cuba

1884-1886 Cuba

$1885 \quad$ Cuba

1887-1889 Cuba

\footnotetext{
* The date of composition was not found for this opera.
} 


\section{Appendix J: \\ Central America and the Caribbean: Operas by Country}

\begin{tabular}{|c|c|c|c|c|}
\hline Country & Year & Title & Composer & Librettist \\
\hline \multirow[t]{15}{*}{ Cuba } & 1867 & Angelo, tirano de Padua & Villate, Gaspar & \\
\hline & 1871 & $\begin{array}{l}\text { Las primeras armas de } \\
\text { Richelieu }\end{array}$ & Villate, Gaspar & \\
\hline & 1875 & La hija de Jefté (Seila) & Fuentes Matons, Laureano & \\
\hline & 1877 & Zilia & Villate, Gaspar & \\
\hline & 1880 & La czarina & Villate, Gaspar & \\
\hline & $\begin{array}{l}1884- \\
1886\end{array}$ & Cristóforo Colombo & Villate, Gaspar & \\
\hline & 1885 & Baltazar & Villate, Gaspar & \\
\hline & $\begin{array}{l}1887- \\
1889\end{array}$ & Lucifer & Villate, Gaspar & \\
\hline & 1898 & Yumurí & $\begin{array}{l}\text { Sánchez de Fuentes, } \\
\text { Eduardo }\end{array}$ & $\begin{array}{l}\text { Fernández de Castro, } \\
\text { Rafael }\end{array}$ \\
\hline & 1901 & El náufrago & $\begin{array}{l}\text { Sánchez de Fuentes, } \\
\text { Eduardo }\end{array}$ & \\
\hline & 1911 & La Dolorosa & $\begin{array}{l}\text { Sánchez de Fuentes, } \\
\text { Eduardo }\end{array}$ & Uhrbach, Federico \\
\hline & 1918 & Doreya & $\begin{array}{l}\text { Sánchez de Fuentes, } \\
\text { Eduardo }\end{array}$ & Cabrisas, Hilarión \\
\hline & 1921 & La esclava & Mauri Esteve, José & Juliá, Tomás \\
\hline & $*$ & $\begin{array}{l}\text { Con Papaner o la burla } \\
\text { del hipnotismo }\end{array}$ & Martínez Corres, Cristóbal & \\
\hline & $*$ & El diablo contrabandista & Martínez Corres, Cristóbal & \\
\hline \multirow{2}{*}{$\begin{array}{l}\text { Dominican } \\
\text { Republic }\end{array}$} & $*$ & América & Claudio, Pablo & \\
\hline & $*$ & María de Cuéllar & Claudio, Pablo & \\
\hline \multirow[t]{2}{*}{ Guatemala } & $\begin{array}{l}1919- \\
1924\end{array}$ & Quiché Vináte & Castillo, Jesús & \\
\hline & 1936 & Nicté & Castillo, Jesús & \\
\hline $\begin{array}{l}\text { Puerto } \\
\text { Rico }\end{array}$ & $*$ & Amor de un pescador & Gutiérrez, Felipe & \\
\hline
\end{tabular}

* The date of composition was not found for this opera. 


\section{Bibliography}

Alier, Roger. 2001 "Tonadilla." In Grove Music Online. Accessed 21 Mar. 2019. http://www.oxfordmusiconline.com/grovemusic/view/10.1093/gmo/9781561592630.001. 0001/omo-9781561592630-e-0000028100.

Alzate, Carolina and Rondy Torres. José María Ponce de León y la ópera en Colombia en el siglo XIX \& Ester. Bogotá, Colombia: Universidad de los Andes, Facultad de Artes y Humanidades, Departamento de Música, 2014.

Amat, Carlos Gómez. 2001 "Turina (Pérez), Joaquín." In Grove Music Online. Accessed 25 Mar. 2019.

http://www.oxfordmusiconline.com/grovemusic/view/10.1093/gmo/9781561592630.001. 0001/omo-9781561592630-e-0000028603.

Anaya Arze, Franklin. La música en Latinoamérica y en Bolivia. Cochabamba, Bolivia: Editorial Serrano, 1994.

Arellano, Ignacio and José Antonio Rodríguez Garrido, eds. El teatro en la Hispanoamérica colonial. Madrid: Iberoamericana, 2008.

Arrom, José Juan. El teatro de Hispanoamérica en la época colonial. Habana, Cuba: Ucar García, 1956.

Auza León, Atiliano. Historia de la música boliviana. Sucre, Bolivia: Tupac Katari, 1982.

Bagüés, Jon. 2001 "Escudero, Francisco." In Grove Music Online. Accessed 20 Mar. 2019. http://www.oxfordmusiconline.com/grovemusic/view/10.1093/gmo/9781561592630.001. 0001/omo-9781561592630-e-0000008979.

Balada, Leonardo. "Leonardo Balada: Opera.” Accessed 19 Apr. 2019. https://www.andrew.cmu.edu/user/balada/compositions_opera.htm

Bardin, Pablo, Melanie Plesch, Pola Suárez Urtubey, Federico Monjeau, Pablo Kohan, and Pablo Gianera. Los caminos de la música Europa y Argentina. Jujuy, Argentina: Editorial de la Universidad Nacional de Jujuy, 2008.

Batista, Gustavo. Felipe Gutiérrez y Espinosa (1825-1899): Y el ambiente musical en el San Juan de su época. San Juan, Puerto Rico: BiblioGráficas, 2015.

Béhague, Gerard. Music in Latin America: An Introduction. Englewood Cliffs, NJ: Prentice-Hall, Inc., 1979.

Bethell, Leslie. A Cultural History of Latin America: Literature, Music and the Visual Arts in the $19^{\text {th }}$ and $20^{\text {th }}$ Centuries. New York: Cambridge University Press, 1998. 
Bolt, Rodney. Lorenzo Da Ponte: the Extraordinary Adventures of the Man behind Mozart. London: Bloomsbury Publishing, 2010.

Boyd, Malcolm and Juan José Carreras, eds. Music in Spain During the Eighteenth Century. New York, NY: Cambridge University Press, 1998.

Caamaño, Roberto. La historia del Teatro Colón 1908-1968. Buenos Aires, Argentina: Editorial Cineta S.R.L., 1969.

Carlos, Vega. Música sudamericana. Buenos Aires, Argentina: Emecé Editores, S.A., 1946.

Campos, Ruben M. El folklore musical de las ciudades: investigación acerca de la música mexicana para bailar y cantar. México: La Secretaria de Educación Publica, Talleres Linotipograficos "El Modelo," 1930.

Campos, Ruben M. El folklore y la música Mexicana: Investigación cerca de la cultura musical en México (1525-1925). México: La Secretaria de Educación Publica, Talleres Gráficos de la Nación, 1928.

Carpentier, Alejo. Music in Cuba. Minneapolis, MN: Regents of the University of Minnesota, 2001.

Carreras, Juan José. "From Literes to Nebra: Spanish dramatic music between tradition and modernity." In Music in Spain During the Eighteenth Century, edited by Malcolm Boyd and Juan José Carreras, 7-16. New York, NY: Cambridge University Press, 1998.

Casares Rodicio, Emilio and Álvaro Torrente, eds. La ópera en España e Hispanoamérica. Madrid: Instituto Complutense de Ciencias Musicales, 1999.

Casares Rodicio, Emilio. La ópera en España: procesos de recepción y modelos de creación: I. Desde Carlos IV al period fernandino (1787-1833). Madrid, Spain: Ediciones del ICCMU, 2018.

Cazurra, Anna. 2001 "Duran, Josep." In Grove Music Online. Accessed 20 Mar. 2019. http://www.oxfordmusiconline.com/grovemusic/view/10.1093/gmo/9781561592630.001. 0001/omo-9781561592630-e-0000008374.

Ceballos, Edgar. La ópera: 1901-1925. México, D.F.: Escenología, A.C., 2002.

Chase, Gilbert. The Music of Spain, $2^{\text {nd }}$ ed. New York, NY: Dover Publications, Inc., 1959.

—. "Origins of the Lyric Theater in Spain." The Musical Quarterly 25, no. 3 (1939): 292-305. http://www.jstor.org/stable/738745.

Cotarelo y Mori, D. Emilio. Orígenes y establecimiento de la ópera en España hasta 1800. Madrid, Spain: Revista de Arch., Bibl. y Museos, 1917. 
Cureses de la Vega, Marta. Tomás Marco: la música española desde las vanguardias. Madrid, Spain: ICCMU, 2007.

Díaz Du-Pond, Carlos and Edgar Ceballos. 100 años de ópera en México. México D.F.: Escenología, A.C., 2003.

Ficher, Miguel, Martha Furman Schleifer, and John M. Furman. Latin American Classical Composers: A Biographical Dictionary, $2^{\text {nd }}$ ed. Lanham, Maryland: Scarecrow Press, Inc., 2002.

Gasta, Chad M. Transatlantic Arias: Early Opera in Spain and the New World. Madrid: Iberoamericana, 2013.

Gembero Ustárroz, María and Emilio Ros-Fábregas, eds. La música y el Atlántico: relaciones musicales entre España y Latinoamérica. Granada, Spain: Editorial Universitario de Granada, 2007.

Gesualdo, Vicente. Breve historia de la música en la Argentina. Buenos Aires, Argentina: Editorial Claridad, 1998.

Heine, Christiane. 2001 "Pablo (Costales), Luis de." In Grove Music Online. Accessed 20 Mar. 2019.

http://www.oxfordmusiconline.com/grovemusic/view/10.1093/gmo/9781561592630.001. 0001/omo-9781561592630-e-0000020636.

Henken, John Edwin. 2001 "Barbieri, Francisco Asenjo." In Grove Music Online. Accessed 1 Apr. 2019.

http://www.oxfordmusiconline.com/grovemusic/view/10.1093/gmo/9781561592630.001. 0001/omo-9781561592630-e-0000002006.

Iglesias, Antonio. El Teatro Real de Madrid: teatro de la ópera. Madrid: Editorial Complutense, S.A., 1996.

Kuss, Malena, ed. Music in Latin America and the Caribbean: An Encyclopedic History, Vol. 1, Performing Beliefs: Indigenous Peoples of South America, Central America, and Mexico. Austin: University of Texas Press, 2004.

Link, Dorothea. 2001 "Martín y Soler, (Atanasio Martín Ignacio) Vicente." In Grove Music Online. Accessed 16 Mar. 2019. http://www.oxfordmusiconline.com/grovemusic/view/10.1093/gmo/9781561592630.001. 0001/omo-9781561592630-e-0000017943.

López-Arias, Julio, and Gladys M. Varona-Lacey. Latin America: An Interdisciplinary Approach. New York: Peter Lang Publishing, Inc., 1999. 
Luisa de la Garza Chávez, María, ed. Los sonidos de nuestros pueblos: escuchas desde el sur. Chiapas, México: Universidad de Ciencias y Artes de Chiapas, 2016.

Marco, Tomás. Spanish Music in the Twentieth Century. Translated by Cola Franzen. Cambridge, MA: Harvard University Press, 1993.

Martín de Sagarmínga, Joaquín. Mitos y Susurros 50 Años de Lírica en España. Alcalá la Real: Editorial Zumaque, 2010.

Mayer-Serra, Otto. Música y musicos de Latinoamérica, 2 vols. México D.F.: Editorial Atlante, S.A., 1947.

- Panorama de la música mexicana: desde la independencia hasta la actualidad. México: El Colegio de México, 1941.

Mendoza, Vicente T. Panorama de la música tradicional de México. Mexico, D.F.: Imprenta Universitaria, 1956.

Miranda, Ricardo. Ecos, alientos, y sonidos: ensayos sobre música mexicana. Xalapa, México: Universidad Veracruzana, 2001.

Molina Siverio, Julio. Alborada del arte lírico en Costa Rica. Cartago, Costa Rica: Talleres Gráficos de Litografia e Imprenta Segura Hermanos S.A., 1999.

Morena Rivas, Yolanda. La composición en México en el siglo XX. México D.F.: Consejo Naciónal para la Cultura y las Artes, 1996.

Nettl, Bruno. Folk and Traditional Music of the Western Continents, $2^{\text {nd }}$ ed. Englewood Cliffs, NJ: Prentice-Hall, Inc., 1973.

Nettl, Bruno, Charles Capwell, Isabel K.F. Wong, Thomas Turino, and Philip V. Bohlman. Excursions in World Music, $4^{\text {th }}$ ed. Upper Saddle River, NJ: Pearson Prentice Hall, 2004.

Noble, Ernestina L., and Ricardo Kirschbaum. El gran libro del Teatro Colón : su música, su historia, su esplendor. 7 vols. Buenos Aires: Clarín, 2010.

Noske, F. R. "Don Giovanni: Musical Affinities and Dramatic Structure." Studia Musicologica Academiae Scientiarum Hungaricae 12, no. 1/4 (1970): 167-203. doi:10.2307/901357.

Peña y Goñi, Antonio. La ópera española y la música dramática en España en el siglo XIX. Madrid, Spain: Imprenta y Estereotipia de El Liberal, 1881.

Perdomo Escobar, José Ignacio. La ópera en Colombia. Bogotá, Colombia: Litografía Arco, 1979.

Pereira Salas, Eugenio. Los orígenes del arte musical en Chile. Santiago, Chile: Universitaria, 
1941.

Robinson, Michael F. "Financial management at the Teatro de los Caños del Peral." In Music in Spain During the Eighteenth Century, edited by Malcolm Boyd and Juan José Carreras, 29-52. New York, NY: Cambridge University Press, 1998.

Romero, Jesús C. La ópera en Yucatán. México D.F.: Ediciones Guión de América, 1947.

Sadie, Julie Anne. Companion to Baroque Music. New York: Schirmer Books, 1990.

Saenz Garcia, Alfredo. Teatro lírico La Paz. La Paz, Bolivia: Ante Proyecto, 1948.

Salgado, Susana. Breve historia de la música culta en el Uruguay, $2^{\text {nd }}$ ed. Montevideo, Uruguay: A. Monteverde y Cia. S.A., 1980.

Sánchez Málaga, Armando. Nuestros otros ritmos y sonidos: la música clásica en el Perú. Lima, Peru: Fondo Editorial del Congreso del Perú, 2012.

Sánchez Novelo, Faulo M. La recreación en Yucatán durante el segundo imperio (1864-1867): teatro, ópera, música y otras diversiones. Merida, México: Maldonado Editores del Mayab, 1999.

Sosa, Octavio. La ópera en Guadalajara. Guadalajara, México: Secretaria de Cultura, 2002.

Stein, Louise K. Songs of Mortals, Dialogues of the Gods: Music and Theatre in SeventeenthCentury Spain. New York, NY: Oxford University Press, 1993.

_ 2001 "Auto." In Grove Music Online. Accessed 21 Mar. 2019. http://www.oxfordmusiconline.com/grovemusic/view/10.1093/gmo/9781561592630.001. 0001/omo-9781561592630-e-0000001566.

Stein, Louise K., and Roger Alier. 2001 "Zarzuela." In Grove Music Online. Accessed 24 Mar. 2019. http://www.oxfordmusiconline.com/grovemusic/view/10.1093/gmo/9781561592630.001. 0001/omo-9781561592630-e-0000040742.

Stein, Louise K., and José Máximo Leza. "Opera, genre, and context in Spain and its American colonies." In The Cambridge Companion to Eighteenth-Century Opera, edited by Anthony R. DelDonna and Pierpaolo Polzonetti, 244-269. New York: Cambridge University Press, 2009.

Stevenson, Robert. Foundations of New World Opera. Lima, Peru: Ediciones "CVLTVRA," 1973.

- Music in Aztec and Inca Territory. Berkeley and Los Angeles, CA:

University of California Press, 1968. 
-. Music in Mexico: A Historical Survey. New York: Thomas Y. Crowell Company, 1952.

Suárez-Pajares, Javier, ed. Música española entre dos guerras, 1914-1915. Granada, Spain: Archivo Manuel de Falla, 2002.

Subirá, José. Historia de la música española e hispanoamericana. Barcelona, Spain: Salvat Editores, S.A., 1953.

—. Historia de la música teatral en España. Barcelona, Spain: Editorial Labor, S.A., 1945.

Tello, Aurelio. La música en México: Panorama del siglo XX. México D.F.: Fondo de Cultura Económica Consejo Nacional para la Cultura y Las Artes, 2010.

Tinnell, Roger. Catálogo anotado de la música española contemporánea basada en la literature española. Granada, Spain: Editorial Comares, S. L., 2001.

Valenti Ferro, Enzo. Historia de la ópera argentina. Buenos Aires, Argentina: Ediciones de Arte Gaglianone, 1997. 